UNIVERSIDAD SANTO TOMAS

\title{
FORMALIZACIÓN DE TIERRAS EN RAMIRIQUÍ BOYACÁ: UNA EXPERIENCIA SOCIO - COMUNICATIVA
}

Fabián Ernesto Martínez Morales

Universidad Santo Tomás

Maestría en Comunicación, Desarrollo y Cambio Social Bogotá, Colombia

2017 



\section{FORMALIZACIÓN DE TIERRAS EN RAMIRIQUí BOYACÁ: UNA EXPERIENCIA SOCIO - COMUNICATIVA}

\section{Fabián Ernesto Martínez Morales}

Trabajo de investigación presentado como requisito parcial para optar al título de:

Magister en Comunicación, Desarrollo y Cambio Social

Directora:

Mg. Sonia Uruburu Giléde

Comunicación, gobierno y ciudadanía:

Comunicación, desarrollo y cambio social

Universidad Santo Tomás

Facultad de Comunicación Social

Bogotá, Colombia 2017 



\section{Resumen}

La formalización de predios a lo largo y ancho del territorio nacional es fundamental para fortalecer la economía, puesto que ayuda a consolidar bases sólidas para el desarrollo del país y aporta a la reconstrucción del tejido social, degradado por las diferentes problemáticas que afectan al campesinado colombiano y que no lo dejan a acceder al desarrollo propio y, por ende, a la superación de los factores que por muchos años han alimentado la violencia.

Aspecto, que le da pertinencia a la investigación en la maestría en Comunicación, Desarrollo y Cambio Social, permitiendo un acercamiento a los procesos socio-comunicativos del programa de formalización de tierras, gracias a la estrategia promovida por el municipio de Ramiriquí, atendiendo el programa formalización propiedad rural realizado por el Ministerio de Agricultura, que buscó en su momento ofrecer una solución pronta y efectiva dirigida a la población rural, que no contaba con una escritura que demostrará su titularidad. Para tal fin, el objetivo propuesto fue visibilizar cuáles fueron los resultados de la estrategia socio - comunicativa sobre el desarrollo y cambio social aplicada al programa formalización de tierras, en Ramiriquí - Boyacá planteado en el 2012 por el Ministerio de Agricultura

De ahí que, el diseño metodológico propuesto, fue (a) partir de un estudio de caso lo que permitió la descripción y análisis de las cualidades del fenómeno objeto de estudio, acompañado de un trabajo de campo realizado por medio de visitas registradas en un diario de observación de la realidad social y el análisis e interpretación del proceso de las piezas comunicativas. (Lo que permitió)Concluir que la incidencia de la estrategia comunicativa desbordó por completo la infraestructura del municipio para atender las debidas reclamaciones, dando como resultado que el municipio no pudiera ofrecer en últimas, la continuidad del programa.

Palabras clave: Formalización de tierras, comunicación, desarrollo rural, economía rural, campesinado. 


\section{Contenido}

pág.

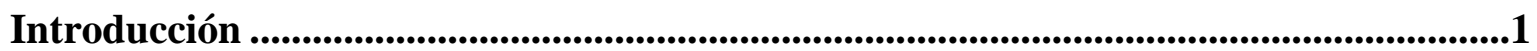

1. Capítulo 1 ......................................................................................................................................

$1.1 \quad$ Planteamiento del problema ......................................................................... 4

1.1.1 Pregunta de investigación .................................................................................6

1.1.2 Preguntas generadoras ………………………….........................................

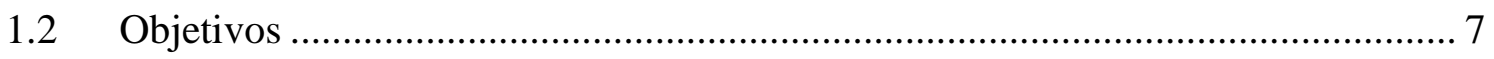

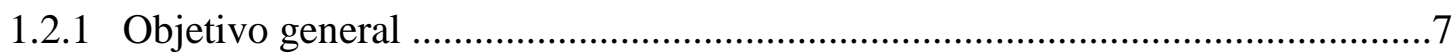

1.2.2 Objetivos específicos ................................................................................

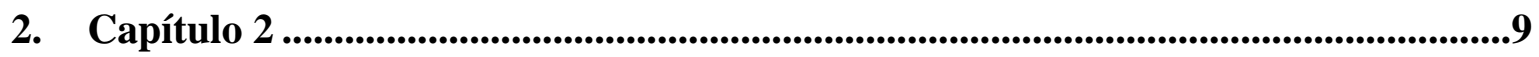

2.1 Antecedentes de investigación .................................................................... 9

3. Capítulo 3. ........................................................................................................................20

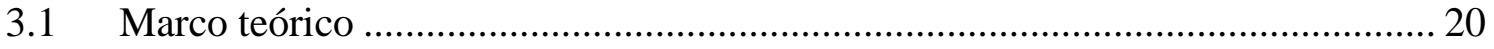

3.1.1 La comunicación para el desarrollo de las comunidades ....................................20

3.1.2 El territorio en el dinamismo del mundo actual ................................................23

3.1.3 Comunidades un término inacabado................................................................26

3.1.4 Campesinado un concepto lleno de inequidades ...............................................28

3.1.5 La economía rural vista desde el desarrollo entre aciertos y desaciertos ...........33

3.1.6 El desarrollo como pilar de crecimiento, desde un contexto comunitario..........38 


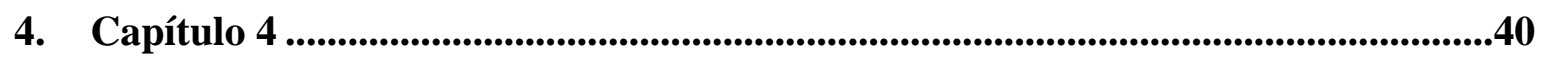

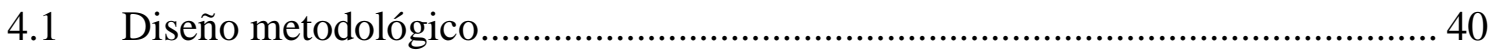

4.1.1 Enfoque epistemológico hermenéutico interpretativo ........................................40

4.1.2 Metodología: cualitativa ...............................................................................

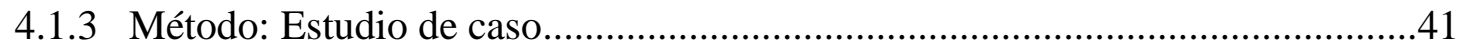

4.1.4 Técnicas de investigación ...........................................................................42

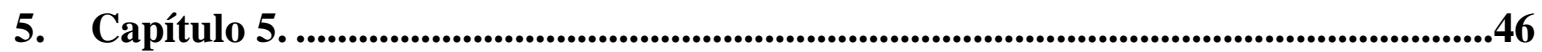

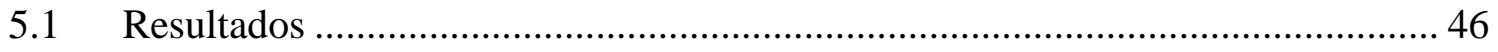

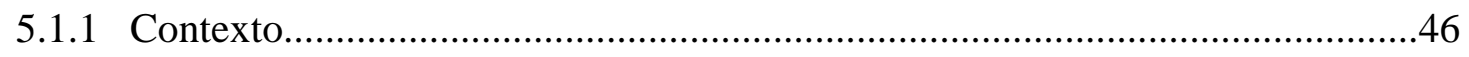

5.1.2 Identificación de la estrategia socio - comunicativa que se implementó en el proyecto de formalización de tierras de Ramiriquí - Boyacá.

5.1.3 Análisis del alcance de la estrategia socio - comunicativa utilizada para la formalización de tierras en Ramiriquí - Boyacá.

5.1.3.1. Etapas de la estrategia socio - comunicativa utilizada para la formalización de tierras en Ramiriquí - Boyacá ..............................................................................53

5.1.3.2. Resultados guía de observación .................................................................58

5.1.3.3. Resultados de la entrevista ...................................................................62

5.1.3.4. Estrategia socio - comunicativa .......................................................66

6. Conclusiones y recomendaciones .........................................................................................87

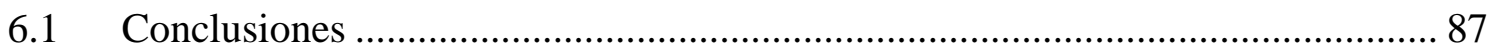

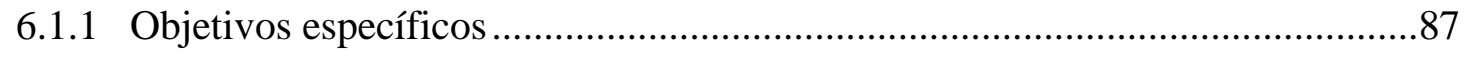

6.2 Recomendaciones...................................................................................... 90

7. Bibliografía ................................................................................................................................91

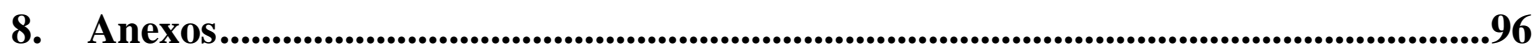




\section{Lista de tablas}

pág.

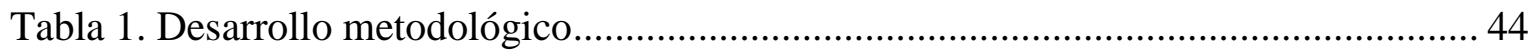

Tabla 2. Solicitudes de Formalización de Propiedad Rural ................................................. 50

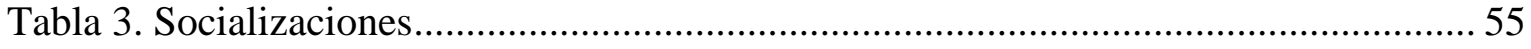

Tabla 4. Discriminación de visitas realizadas ..................................................................... 56

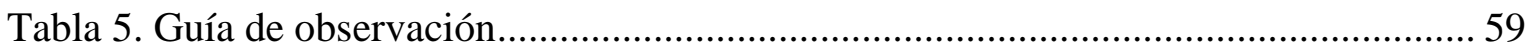

Tabla 6. Resumen de la estrategia - socio comunicativa.................................................. 78 


\section{Lista de figuras}

pág.

Figura 2. Mapa del municipio de Ramiriquí.................................................................. 47

Figura 3. Mapa de Formalización de Propiedad Rural de Ramiriquí. ................................... 51

Figura 4. Aviso publicado de socializaciones .................................................................... 54

Figura 5. Formato de predio visitado .......................................................................... 57

Figura 6. Proceso de la herramienta comunicativa ......................................................... 67

Figura 7. Programa de la formalización de la propiedad rural ............................................. 68

Figura 8. Cuñas publicitarias de la pieza informativa sobre formalización de tierras en

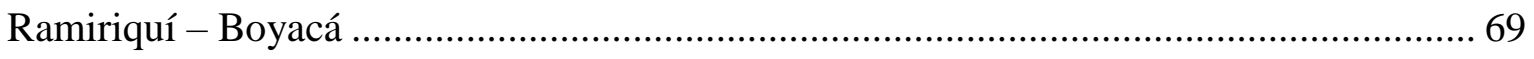

Figura 9. Jornadas de socialización ............................................................................... 72

Figura 10. Diseño de la cartilla sobre formalización de tierras .......................................... 75 


\section{Lista de anexos}

pág.

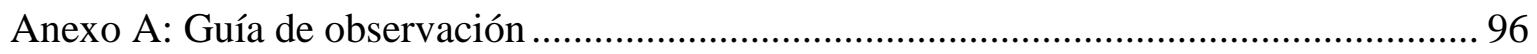

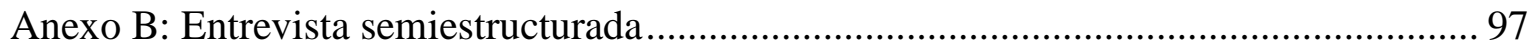

Anexo C: Pasos para la formalización de tierras ………………………………………... 98

Anexo D. Anunció en el periódico El Diario....................................................................... 96

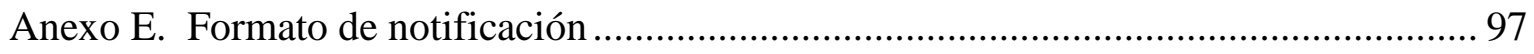

Anexo F: Carteleras del cronograma de visitas en la Alcaldía de Ramiriquí, oficina USTA

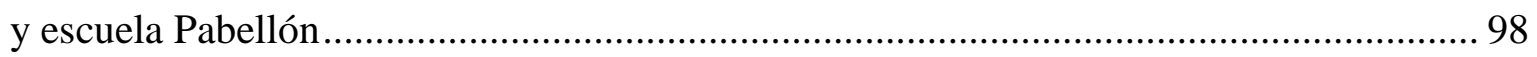

Anexo G: Alcance de las jornadas de socialización ............................................................ 99 


\section{Introducción}

La presente investigación se basa en el proceso del cual hice parte como integrante del equipo de la universidad Santo Tomás en calidad de consultor, en el programa de formalización de la propiedad rural promovido por el Ministerio de Agricultura (2014), con el fin de establecer sí las expectativas que se generaron frente al programa de formalización de tierras se cumplieron, a través del componente comunicativo.

De esta forma, la propuesta socio - comunicativa tenida en cuenta, para la formalización de tierras en el municipio de Ramiriquí - Boyacá, se constituyó en una buena oportunidad para visibilizar aquellos aspectos determinantes que permitieron o no quelas estrategias comunicativas lograran los objetivos propuestos; para tal fin, la universidad Santo Tomás contrató una (la) consultoría en el 2015, en la que el investigador del presente trabajo, tuvo la oportunidad de participar como líder social con funciones que se orientaron a la promoción de la comunicación asertiva, el desarrollo y participación comunitaria, la resolución y manejo de conflictos y el empoderamiento de las comunidades, que sirvieron luego para desarrollar el trabajo propuesto, frente al proceso adelantado en el municipio de Ramiriquí.

La formalización de tierras constituye una de las prioridades de la agenda del segundo mandato del gobierno Santos (2014 - 2018), en la que se propone mejorar las condiciones de vida de las personas y las familias que tienen los predios en informalidad. De esta forma, el gobierno diseño y escogió como municipio pionero a Ramiriquí en el departamento de Boyacá, siendo aplicada en el año 2014. 
La formalización de tierras a lo largo y ancho del territorio nacional es fundamental para la consolidación de la economía del país; puesto que cimienta las bases del desarrollo y reconstrucción del tejido social, degradado por las diferentes problemáticas que afectan al campesinado colombiano; impidiéndole su plena inserción en el aparato productivo como sujetos plenos de derechos y artífice de su propio destino.

Es así, como el Ministerio de Agricultura y Desarrollo Rural - en adelante MADR - creó el programa Nacional de Formalización de la propiedad rural, a través de la resolución No. 452 de 2010, modificada por la resolución 181 de $2013^{1}$, con el fin de promover el acceso a la propiedad de la tierra y mejorar la calidad de vida de los campesinos.

Actualmente "se estima que el 58.8\% de predios rurales en Colombia, que corresponden a más o menos 2.000.000 de predios, se encuentran en la informalidad, según las cifras del Minagricultura" (Ámbito Jurídico, 2015, pág. 1). Aspecto que resulta determinante para lograr establecer el desarrollo en los municipios de país, pues sin lugar a duda la tierra constituye el soporte económico para generar desarrollo y qué mejor si se encuentra en manos de la gente del campo, quienes son la población que más se ha visto afectada por el despojo secular de sus predios.

Dentro de la dinámica que ha comenzado el MADR se debe tener en cuenta, aquella que soportan la parte regulatoria, como es el presentar esta iniciativa a través de diferentes mecanismos como la comunicación, que desde (sus)variados tópicos intenta dar a conocer un tema de responsabilidad social, por medio de diversas piezas comunicativas como las establecidas por el MADR (2013) organizadas en cuatro segmentos: Institucional, organismos gubernamentales y no gubernamentales; población en general con énfasis en organizaciones sociales; población municipal y mujeres.

\footnotetext{
${ }^{1}$ Crea el Programa de Formalización de la Propiedad Rural, con el objeto de promover el acceso a la propiedad de la tierra y mejorar la calidad de vida de los campesinos y en este sentido impulsar y coordinar acciones encaminadas a la regularizar la tenencia individual y colectiva de los predios rurales, los derechos de propiedad y consolidar una cultura de la formalización de la propiedad.
} 
Razón por la cual, se hizo un despliegue informativo y socio - comunicativo por todos los medios de comunicación masiva - radio, prensa, televisión - acerca de la implementación del proyecto, generándose así una serie de expectativas en la consecución de los objetivos propuestos, dentro de los cuales están el sanear derechos y otorgar títulos de propiedad a los campesinos de Ramiriquí que hayan venido ejerciendo una constante posesión sobre un predio. En este sentido, se integró a lo propuesto, una estrategia comunicativa ofrecida por el gobierno, a través del Ministerio de Agricultura, que tenía como objetivo, dar a conocer los lineamientos del programa.

La investigación se divide en seis capítulos, siendo el primero el que integra los aspectos preliminares que obedecen a la propuesta, a través de la problemática, pregunta de investigación y objetivos; el segundo el estado del arte que se orientó en la búsqueda de experiencias socio - comunicativas relacionadas con formalización de tierras; el tercero el marco teórico que se consolidó a partir de las siguientes categorías: comunicación para el desarrollo, territorio, comunidades, campesinado, economía rural y desarrollo, temas todos inherentes al objeto de la investigación. El cuarto capítulo es el diseño metodológico que parte de un enfoque hermenéutico - interpretativo; de este modo, la hermenéutica se entiende como una actividad de reflexión, que permite la interpretación orientada a facilitar el pleno entendimiento de los contextos por los que ha atravesado la humanidad. Acompañado de un método cualitativo, que tiene como objetivo la problematización y análisis de las cualidades de un fenómeno que abarca parte de la realidad del objeto de estudio. El quinto y sexto capítulo contienen los resultados obtenidos y análisis de los mismos y por último las conclusiones. 


\section{Capítulo 1}

\subsection{Planteamiento del problema}

La presente investigación se enmarca en la línea de comunicación, gobierno y ciudadanía, propuesta por la Universidad Santo Tomás, la cual posibilita la afirmación de procesos de organización, movilización y protesta social, el reconocimiento y apropiación de los "mecanismos de participación formales e informales; que permite controlar el ejercicio del poder y la violencia legítima concentrada en el aparato estatal y los gobiernos que la administran, así como el ejercicio, la defensa y promoción de los derechos fundamentales" (Universidad Santo Tomás, 2014, pág. 2). Línea que permite establecer la pertinencia de la investigación; toda vez, que la misma integra comunicación, gobierno y ciudadanía referente al tema de la formalización de tierras.

Así, en el contexto colombiano, uno de los factores estructurales que ha determinado y alimentado el conflicto interno armado del país es la tenencia de las tierras; así, la falta de formalización jurídica de éstas por parte de sus propietarios aunada a las problemáticas de informalidad como consecuencia de la falta de legalización ha generado un fenómeno sociopolítico, económico y cultural generador de destierros, desplazamientos y despojos por el control de los territorios y sus productos. Lo anterior, haciendo énfasis en el papel determinante que juega el territorio como fuente de recursos económicos energéticos para la población rural y urbana donde están asentadas las redes y alianzas sociales, el flujo de información, los procesos comunicativos como el propuesto por el Ministerio de Agricultura (2012), entrada y salida de productos, mercancías y medicamentos, que le permiten al campesinado su sostenibilidad y desarrollo. 
Factor que debiera ser determinante en el municipio de Ramiriquí; debido a que, es el territorio el que permite el desarrollo de la sociedad ramiriqueña en todo su contexto; sin embargo, tal presupuesto no se da, en la forma que se quisiera, debido a que existe una problemática generalizada y que aún no se ha podido superar referente a la formalización de tierras, la cual no se ha logrado consolidar, pese a la existencia de un marco regulatorio que muestra un serio compromiso con el deseo de contribuir a que los campesinos posean los predios y así se genere un mayor dinamismo en cuanto al desarrollo y cambio social en la zona rural municipal.

Razón por la cual, el tema de la formalización de tierras en el municipio de Ramiriquí desde diciembre de 2015 ocupa un lugar prioritario en la agenda municipal gracias al programa de formalización de la propiedad rural que señala que "de un total nacional de 6.192 procesos de formalización iniciados en el segundo semestre de 2015 en seis departamentos, 1003 corresponden a solicitudes presentadas en Ramiriquí” (Minagricultura, 2015, pág. 1). Escogiéndose para validar la información las veredas de Romazal, Caicedo, Pantano Largo, Guacamayas, Común, Nagaut, Farquentao, Escobal 1 y Escobal 2.

Lo expuesto, haciendo énfasis en que tal programa se viene trabajando desde 2012, dado que la formalización de la propiedad rural "se revela desde esta época, como una inversión que revierte en mayores ingresos rurales privados y públicos, mayor acceso de la población campesina a la propiedad de la tierra, uso más racional de ésta y mayor gobernabilidad en el campo" (Alcaldía de Ramiriquí, 2014, pág. 1) Situación que lleva a determinar, que el programa requiere de todas las estrategias para que logre los objetivos deseados en la restitución de los predios a los campesinos y espacio en el que la estrategia socio comunicativa propuesta por el Ministerio de Agricultura (2012) resulta relevante.

Así, los aspectos arriba señalados constituyen la razón de ser de la presente investigación, en pro de establecer sí las dinámicas propuestas con la estrategia socio - comunicativa logró los efectos deseados. Haciendo, claridad que se escogió Ramiriquí por ser cabecera municipal y cuya historia se enmarca en la más genuina tradición indígena siendo un territorio ocupado por los Chibchas, cuna de la dinastía de los Zaques de Ramiriquí. 
"Desarrollaron la orfebrería como verdaderos maestros y de la cual se conservan importantes vestigios. Sus prácticas funerarias son, igualmente, reconocidas por su majestuosidad lo que evidencia la valoración de la muerte como un hecho positivo y trascendental dentro de su cosmovisión" (Alcaldía Municipal de Ramiriquí, 2015, pág. 1).

Los productos agrícolas especialmente el maíz constituían la base de su alimentación que hasta la actualidad han sido parte del sustento de su economía y que ha contribuido al desarrollo de su región, siendo determinante no solo por su territorio sino también por las provincias y los productos que brotan de sus terrenos, "proyectándose a la fecha como un polo de desarrollo económico, social, cultural y político de la región boyacense; gracias, al gran potencial económico, que se origina del sector primario, tales como: agricultura básicamente representada por cultivos frutales y hortalizas" (Ramiriquí Boyacá 1541 - 2007, 2007, pág. 1) y a su vez actividades generadas de la pesca, la silvicultura, la ganadería y la conservación de zonas de invaluables riquezas naturales, fuentes hídricas, montes y paramos andinos; elementos fundamentales para el desarrollo de la región, convirtiendo a Ramiriquí en un territorio con vocación agrícola y pecuaria por excelencia.

A este gran potencial económico se le atraviesa sin embargo la informalidad jurídica de los predios de los habitantes del municipio, especialmente los de la zona rural, puesto que obstaculiza el desarrollo económico y social de los mismos y de la región, por la falta de documentación legal que necesitan para tramitar préstamos, vender o hipotecar y para incentivar la producción y explotación de sus parcelas.

\subsubsection{Pregunta de investigación}

¿Cuál fue el aporte de la estrategia socio - comunicativa que se utilizó en el proyecto denominado formalización de tierras en Ramiriquí Boyacá, propuesto por el Ministerio de Agricultura en el marco del plan de desarrollo y cambio social? 


\subsubsection{Preguntas generadoras}

- ¿Cuál fue la estrategia socio-comunicativa que se implementó en el proyecto formalización de tierras en Ramiriquí Boyacá?

- ¿Cómo se implementó esa estrategia socio - comunicativa en el municipio de Ramiriquí?

- ¿Cómo fue acogida la estrategia socio - comunicativa en el municipio de Ramiriquí?

- ¿Cuáles fueron los logros y dificultades que se lograron determinar en la implementación de la estrategia socio - comunicativa propuesta por el Ministerio de Agricultura en el municipio de Ramiriquí - Boyacá?

\subsection{Objetivos}

\subsubsection{Objetivo general}

Analizar la estrategia socio-comunicativa que se utilizó en el proyecto de formalización de tierras en Ramiriquí Boyacá, propuesto por el Ministerio de Agricultura en el marco de la estrategia para el desarrollo y el cambio social

\subsubsection{Objetivos específicos}

- Identificar la estrategia socio - comunicativa que se implementó en el proyecto de formalización de tierras en Ramiriquí Boyacá.

- Analizar el alcance de la estrategia socio - comunicativa, utilizada en el municipio de Ramiriquí para la formalización de tierras. 
Establecer los logros y dificultades en la implementación de la estrategia socio comunicativa propuesta por el Ministerio de Agricultura en el municipio de Ramiriquí Boyacá. 


\section{Capítulo 2}

\subsection{Antecedentes de investigación}

El desarrollo del presente capítulo condensa las investigaciones, artículos, e informes que se consideraron pertinentes para dar cuenta de los diferentes tópicos de como se ha abordado el tema de la formalización de tierras, a través de la estrategia socio - comunicativa; estableciéndose de primera mano que los documentos que se escogieron cumplen con las especificaciones necesarias para lograr un contexto de lo que se busca plantear en la presente investigación.

Así, la búsqueda se realizó en las diferentes universidades de Bogotá y fuera de Bogotá específicamente en Tunja y Ramiriquí, con el fin de tener una perspectiva más amplia; toda vez, que no todas las investigaciones en la materia se encuentran en las bibliotecas públicas de Bogotá, o en las sedes de las diferentes universidades Santo Tomás, Nacional, Javeriana, Andes y Externado de Colombia; búsqueda que se completó accediendo a las bibliotecas virtuales de otras instituciones fuera de Bogotá. Adicionalmente, se hizo una revisión en la biblioteca Luis Ángel Arango y en la red mundial de datos Internet.

Es de aclarar, que, haciendo la discriminación del tema, en cuanto a la estrategia socio comunicativa para el desarrollo, son muy pocas las investigaciones encontradas. Con relación a la formalización de tierras son muchas las que existen, la gran mayoría en el contexto del conflicto armado; razón por la cual, no se tuvieron en cuenta, salvo aquellas que, por el marco normativo, sirven a la investigación. En cuanto al desarrollo rural y urbano, son muchas las referencias, pero no desde la experiencia socio - comunicativa, sino 
desde otras áreas del conocimiento - sociología, derecho, ingenierías, psicología, entre otras

Por último, se descartaron las investigaciones que superan los 20 años debido a que la información ya se encuentra desactualizada; es decir, se tuvieron en cuenta aquellas que no alcanzan los diez años de realizadas.

Para dar comienzo, se cita el texto de Chaves (2012) Comunicación para el cambio social. Universidad, sociedad civil y medios, producto del seminario del mismo nombre, realizado en la universidad Rey Juan Carlos en 2011 en el que aborda diferentes aspectos en materia comunicativa, resultando pertinente el capítulo 2 formación en comunicación para el cambio social, balance y desafíos, realizado por Alejandro Barranquero, quien establece que "la comunicación para el desarrollo o para el cambio social es una de las disciplinas más veteranas de la comunicación" (Chaves, 2012, pág. 45). De ahí que, la formación en comunicación en relación con el desarrollo y cambio social parece estar ganando posiciones en los últimos años, en un sentido paralelo a la centralidad que este campo está adquiriendo con relación a la participación de la comunidad, en los temas de su interés, especialmente a nivel municipal, que también puede ser visto como un campo emergente de la comunicación, y no como una disciplina veterana, toda vez que esta emerge conforme a las exigencias del mundo actual entorno a su transformación.

Aspecto que se puede evidenciar en el proceso de formalización de tierras en el municipio de Ramiriquí, que a 2014 ha sido declarado junto con otros 18 municipios en diferentes zonas del país por el Ministerio de Agricultura y Desarrollo Rural - MADR - como zonas de formalización masiva.

(...) en estas zonas se realiza un proceso comunicativo, a través del acompañamiento a las familias para formalizar sus predios, que incluye visitas de campo, inspecciones oculares, levantamientos prediales, recolección de testimonios, actas de colindancia y análisis jurídicos para cada uno de los casos, con el fin de elegir la ruta que garantice a los campesinos la legalización de su tenencia, todo esto acompañado de un fuerte componente social que promueve la formalización como una cultura de arraigo por la tierra (...) (Alcaldía de Ramiriquí, 2014, pág. 1). 
Esta estrategia comunicativa pone de manifiesto un avance, en cuanto a organización se refiere para lograr un mayor alcance en el tema de la formalización de tierras en el municipio de Ramiriquí; debido a que, la comunicación es un espacio dialógico que va acompañado de un discurso político, social y cultural que hace ver a la persona como ser humano de derechos y a su vez permite la interacción entre la comunidad y el gobierno municipal, visibilizando la importancia de la ciudadanía en estos procesos.

En la investigación de Chaves (2010) titulada la comunicación para el desarrollo desde las ONGD: Una aproximación teórica y una muestra práctica, señala el autor que en "el deseo que tiene el ser humano por hacer prevalecer la justicia social y el desarrollo sostenible y equitativo, el papel de la sociedad civil es fundamental, a través de movimientos sociales, asociaciones, entre otras" (Chaves, 2010, pág. 11). Significa, que existe una clara evidencia en la necesidad que la ciudadanía se haga parte y se apropie de los procesos de cambio generados por el gobierno, para el caso municipal, en donde, ésta no puede seguir inerte frente a las situaciones que requieren de su consenso.

Aspecto que lleva a concluir que "la comunicación ha estado marginada de los proyectos de desarrollo y que sigue siendo en muchos casos, un instrumento de propaganda más que un proceso de diálogo y de participación” (Chaves, 2010, pág. 45). De ahí la importancia de la estrategia comunicativa para incentivar la participación de los usuarios del programa oportunidades rurales "Vamos Bien" que hace referencia a la importancia que tiene la ciudadanía en los procesos de información en el contexto del "Programa de Oportunidades Rurales que busca tomar distancia de la idea de persuasión, no para desecharla sino para verla como una estrategia con la que se pueda hacer posible la reflexión propia y colectiva, a través de un proceso comunicativo" (Fondo Internacional de Desarrollo Agrícola, 2007, pág. 13).

Desde esta perspectiva, la comunicación es una herramienta clave de interacción que permite un seguimiento continuo a las actividades y que garantiza que las decisiones surjan del consenso y el acuerdo entre los interesados. 
En el siguiente artículo de Gumucio (2011) titulado Comunicación para el cambio social: clave del desarrollo participativo, analiza que "la participación de los actores involucrados es esencial en las propuestas de comunicación para el desarrollo, alternativa y participativa, que son las expresiones más reconocidas de la comunicación para el cambio social" (Gumucio, 2011, pág. 28). La comunicación para el desarrollo, además "de valorar el conocimiento local, debe comprender las necesidades de respetar las formas tradicionales de organización social y de fortalecer, para contar con un interlocutor válido y representativo" (Gumucio, 2011, pág. 35). Concluye el artículo que la comunicación para el cambio social es un proceso vivo, que no es fácil de capturar con definiciones académicas (Gumucio, 2011, pág. 38).

Aspecto que se ve reflejado en la estrategia comunicativa de Ramiriquí en lo concerniente a la formalización de tierras debido a que lleva a la práctica todo el componente comunicativo vinculando la población desde una preparación previa, a través de las socializaciones realizadas en diferentes escuelas del municipio, plazas principales, juntas de acción comunal que permitieron la interacción por medio de un lenguaje participativo, claro y sencillo para que la población comprendiera la estrategia comunicativa que se iba a ver reflejada en la comprensión del proceso para la formalización de sus tierras, como se puede constatar en el apartado de resultados de la presente investigación.

El trabajo que a continuación se cita, de Escobar (2012) titulado Una minga para el postdesarrollo: lugar, medio ambiente y movimientos sociales en las transformaciones globales, aborda de una forma cruda y crítica el concepto de desarrollo en América Latina y como éste, aún continúa siendo una utopía, en sociedades como la colombiana. Establece que "desde mediados del siglo XX, el desarrollo fue un fantasma recorriendo América Latina, y en general todo el Tercer Mundo" (Escobar, 2012, pág. 8) y agrega que está lejos de postulados como el que establece que "el desarrollo sería la solución para las desigualdades regionales, para las injusticias sociales, para los bloqueos productivos y comerciales, y, en las visiones más influenciadas por la guerra fría, sería el antídoto para los peligros que afectaban la seguridad nacional” (Escobar, 2012, pág. 8). 
En la siguiente investigación de Martínez, (2015), La tenencia de la tierra, la política ambiental y el desarrollo sostenible: estudio de caso municipios de Ramiriquí y Sachica, se aborda la problemática del desarrollo rural en Colombia, el cual siempre ha sido pensado en "mayor producción de cultivos de exportación y en número de cabezas de ganado, por lo anterior la población y las condiciones en que vive se ha dejado de lado como si el asunto fuera solo económico” (Martínez, 2015, pág. 10). Señala, además, que: “el campo colombiano, por ratos, parece que se está convirtiendo en "tierra sin campesinos y campesinos sin tierra", principalmente por la concentración de la propiedad y la situación de abandono en que se encuentran las personas del campo" (Martínez, 2015, pág. 10).

Establece además el análisis sobre la "tenencia de la tierra rural en Colombia con cifras oficiales desde los años cincuenta en adelante, comparando la norma y protección ambiental, evidenciando el choque normativo y efectos negativos sobre la regularización de la propiedad rural en el país” (Martínez, 2015, pág. 12) por medio de las metodologías ajustadas, que proporcionan los métodos de análisis y comparación de datos sobre la preferencia de la tierra. Finalmente, concluye que la concentración de la tierra se encuentra en manos de unos pocos, situación que se corrobora con el proceso que adelanta el país en materia de formalización de tierras, siendo Ramiriquí uno de los municipios pioneros del ejercicio desarrollado por medio de la estrategia socio - comunicativa desde el año 2012.

En la investigación realizada por Tabares y Álvarez (2014) titulada la formalización de la propiedad rural en Colombia como un soporte de desarrollo local sostenible. Estudio de caso municipio de Samaná, Caldas, se basa fundamentalmente en que "aborda los problemas de la informalidad de la propiedad rural, sus implicaciones en el desarrollo local sostenible en Samaná, Caldas, y su impacto en las condiciones de vida de los habitantes rurales" (Tabares, A y Álvarez, A, 2014, pág. 5).

Señala, además que la propiedad de la tierra ha tenido inconvenientes desde hace tiempo atrás; es por eso por lo que, en el transcurso del siglo XX, ciertos gobiernos han pretendido perfeccionar cambios "agrarios que han tenido como propósito básico la redistribución de la tierra. Dichas reformas que han sido fallidas o incompletas han tenido detrás las 
exigencias de los habitantes rurales que requieren y aspiran a condiciones de equidad en sus territorios" (Tabares, A y Álvarez, A, 2014, pág. 5). Aspecto fundamental para el desarrollo de la investigación, debido a que, si no existiera la problemática de las tierras desde la titularidad, la estrategia socio - comunicativa propuesta por el Ministerio de Agricultura y puesta en práctica en el municipio de Ramiriquí no tendría asidero; de ahí que, el artículo realizado por Tabares, A y Álvarez, A (2014) resulta muy pertinente, por la exposición que hace de las inequidades que existen sobre la propiedad rural.

En este orden de ideas, la metodología que se tuvo en cuenta fue por medio de un enfoque cualitativo por cuanto "utilizaron preferentemente información de este tipo, proveniente de la aplicación de diferentes instrumentos en la población objetivo, que permiten caracterizar el problema de la informalidad, analizar sus implicaciones y determinar las ventajas de la formalidad para el desarrollo local sostenible" (Tabares, A y Álvarez, A, 2014, pág. 50). Acompañada, de momentos cualitativos, a través del estudio de caso utilizando la información obtenida del municipio de Samaná, a través de las 63 veredas, 4 corregimientos restantes, con una muestra intencional que dio como resultado estudiar 102 familias a través de una encuesta "sin importar cuál fuese el corregimiento y la condición en cuanto a la tenencia de los predios - poseedores, tenedores y propietarios -" (Tabares, A y Álvarez, A, 2014, pág. 53). El trabajo de campo se complementó con una entrevista semiestructurada a 12 líderes de la región.

La investigación llegó a la conclusión que "un obstáculo importante para el avance en el trabajo de formalización de predios en Samaná y para la ampliación del programa en otras comunidades, lo constituyen los temores, prevenciones, la falta de información y en algunos casos ciertas prácticas culturales" (Tabares, A y Álvarez, A, 2014, pág. 85). Lo expuesto puede ser superado a través de un proceso educativo en el que gobierno nacional, departamental y municipal reconozcan y realicen el debido acompañamiento a las comunidades.

En el libro de Luna (2013), Tierras despojadas, ¿derechos restituidos? (Des) encuentros acerca del problema de la tierra en Colombia en un escenario de "justicia transicional", 
refleja "una búsqueda académica y social acerca de la concepción que tienen las víctimas, frente al proceso impulsado por el Estado colombiano, para la restitución de tierras a víctimas del despojo por causa del conflicto armado" (Luna, 2013, pág. 15).

La metodología utilizó entrevistas, conversaciones abiertas y participación de espacios de diálogo y "debate hicieron parte del proceso activo de aprendizaje y análisis del desarrollo investigativo, lo que consistió en el planteamiento de preguntas, desde las concepciones mismas de los actores, y el reconocimiento del contexto social y político de los mismos" (Luna, 2013, pág. 16).

Se concluye que "el despojo de tierras y el desplazamiento forzado son fenómenos históricos diferenciados del desarrollo del país y se explican, en gran medida, por el interés de grupos por el control territorial y el dominio político, de acuerdo con el modelo económico hegemónico" (Luna, 2013, pág. 97) que a través de la formalización de tierras se busca desarticular tal hegemonía y dominio político devolviéndole a los campesinos sus tierras, para que el campo colombiano logré nuevamente consolidarse y afianzar la economía rural.

En la siguiente investigación de Araújo (2011) titulada Política integral de tierras. El desafío de la formalización y restitución a despojados se señala que una particularidad del campo colombiano, que ha afianzado los altos niveles de desempleo, subempleo, pobreza e indigencia en las zonas rurales "es la elevada concentración de la propiedad de la tierra y, en consecuencia, la predominancia de minifundios con escalas de producción ineficientes, unida a la existencia de grandes latifundios con tierras subutilizadas o inexplotadas" (Araújo, 2011, pág. 7).

Se concluye que, sobre la restitución no se encuentra un consenso, pues sus detractores, "temerosos de los resultados de la misma, han lanzado ataques desde diversos flancos para desvirtuar la ley misma y su impacto sobre la sociedad. El Estado ha respondido a los señalamientos y temores con contundencia técnica y con voluntad política” (Araújo, 2011) se busca articular la devolución de la tierra a sus dueños, no desde el marco de la restitución que trae anidado el tema del conflicto armado, sino desde la formalización que se constituye 
en proceso participativo, que busca el desarrollo y el cambio social, donde existe un proceso de interacción entre las partes.

En la investigación del Centro Nacional de Memoria Histórica (CNMH) (2013) titulada La política de reforma agraria y tierras en Colombia: esbozo de una memoria institucional, cuyo objetivo identificar las visiones de autores seleccionados sobre la manera como el Estado ha manejado el problema de tierras y su percepción sobre los efectos de esa intervención en la problemática rural y sus conflictos. Así, el documento establece que "la memoria de las políticas públicas hace parte de la memoria histórica del conflicto armado interno en Colombia. Proceso que deberían conocer todos los actores involucrados, incluyendo el Estado y sus organismos centrales y regionales" (Centro Nacional de Memoria Histórica (CNMH), 2013, pág. 10).

La metodología que se siguió fue por medio de entrevistas.

La conclusión a la que se llego fue que "el país no tiene una adecuada memoria e historia de sus políticas de reforma agraria y de tierras. Esta es una tarea pendiente en la agenda de investigación del país a la cual deberían recurrir historiadores y profesionales de las ciencias sociales” (Centro Nacional de Memoria Histórica (CNMH), 2013, pág. 29).

En el artículo de Gómez (2011) titulado La tenencia de la tierra y la reforma agraria en Colombia, nace como resultado de la tesis doctoral del autor, el cual resume la política de tierras y las normas que rigen entorno a la tenencia de estas, partiendo de una descripción de la tenencia de la tierra en Colombia, a través de un análisis "desde el contexto político, partiendo de la década de los 30, época en la que surgió la violencia como consecuencia de las movilizaciones y luchas sociales por la tierra en un contexto de marcada tendencia latifundista" (Gómez, 2011, pág. 64).

Analiza, además que el problema agrario es la carencia “de una decisión política de reformar la estructura agraria en función de objetivos de desarrollo y equidad de largo plazo. Es la no consideración del sector agropecuario como sector estratégico para la sociedad, en términos 
de seguridad alimentaria y dominio territorial” (Gómez, 2011, pág. 67) que como se puede evidenciar en el desarrollo de la investigación, a través de la formalización de tierras, busca lograr la equidad del agro colombiano, por medio de un proceso participativo, dialógico, en donde, la comunidad no es solamente receptora sino que además es parte activa del proceso, buscando con ello, eliminar aquellos derroteros que hacen que el campesino sea ajeno a todo aquello que lo hace un verdadero ciudadano.

La obra de Planeta Paz (2012), titulada la cuestión agraria en Colombia: tierra, desarrollo y paz, se realizó con base a las diferentes problemáticas que se presentan en el campo colombiano por medio de conversatorios que permitieron realizar un mapeo de experiencias organizativas de las comunidades rurales y de las diferentes particularidades que adquiere el problema de la tierra en las regiones según la relación existente entre factores sociodemográficos como: "los recursos medio ambientales, las políticas públicas implementadas, la posición geoestratégica del territorio, las relaciones de poder entre los actores que tienen presencia en la zona, en el contexto de las dinámicas del conflicto interno armado" (Planeta Paz, 2012, pág. 7)La metodología que se siguió fue a través entrevistas a líderes de las organizaciones sociales que estuvieron presentes en los conversatorios.

La conclusión a la que se llegó fue que las temáticas abordadas durante el ciclo de conversatorios arrojan elementos que deben tenerse en cuenta, reiterarse y profundizarse desde diferentes sectores sociales, políticos, académicos e institucionales (Planeta Paz, 2012, pág. 122).

Aspectos que permitirán generar propuestas que vayan más allá de lo jurídico, que respondan a las diversas realidades regionales del campo y que configuran lo que se ha denominado el problema de la tierra y los territorios en Colombia.

En el siguiente artículo de Albán (2011), llamado reformas y contrarreforma agraria en Colombia, se enfatiza en que el tema agrario ha estado manifestado por los altercados por la tierra. El inconveniente, en el que incurren fuerzas sociales, "económicas y políticas, es resultado de la configuración histórica de esta sociedad. La Revolución en Marcha de 
Alfonso López Pumarejo no pasó de dar trámite a la protesta campesina por la propiedad de la tierra, sin modificar las estructuras sociales” (Albán, 2011, pág. 327). Se tiene como conclusión que:

(...) En suma, una reforma agraria induce cambios estructurales en el orden económico y político; requiere la acción del Estado y, por tanto, es o debe ser el resultado de una decisión política de la sociedad; sus efectos transformadores dependen de la profundidad y el alcance de la reforma. En el caso colombiano, la ambigüedad de las reformas y la incoherencia de las políticas estatales han impedido resolver la disputa por el control del trabajo y de la tierra (...) (Albán, 2011, pág. 331).

En cuyo caso, el proceso de formalización de tierras tiene como objetivo acabar con las ambigüedades en el control de la tierra, promoviendo la titularidad de estas a sus dueños.

Por último, la investigación de Holguín y Rodríguez (2015) titulada Alcances de la asociatividad territorial como eje de desarrollo local y regional, para los municipios del Valle de Tenza, en el departamento de Boyacá, analizó el "tema de la asociatividad territorial, como una herramienta de las entidades territoriales para propender por el desarrollo de sus municipios y regiones, a través de estrategias eficaces, teniendo en cuenta las nuevas realidades geográficas y las figuras de organización territorial” (Holguín, M y Rodríguez, J, 2015, pág. 10).

La metodología llevada a cabo fue de tipo descriptivo-analítica.

Como conclusión se tiene que se ven muchas falencias en la normatividad que impide el desarrollo de las asociaciones, aunado a la ausencia de recursos y falta de voluntad política. Por eso, es indispensable el apoyo del gobierno orientado a la formulación de proyectos de carácter regional orientados hacia la asociatividad territorial como eje estratégico de la descentralización en el país.

Estas investigaciones y las demás que se requieran para lograr un trabajo a profundidad en el tema propuesto, constituyen la base teórica, de la que emergen las posturas, análisis, críticas e ideas que van a permitir realizar una tesis, desde un contexto diferente, que busca 
más que evidenciar la problemática en la tenencia de tierras; es saber si existe un pleno conocimiento por parte de los campesinos de Ramiriquí, en lo que pueden o no hacer en la materia, a través de un proceso socio - comunicativo 


\section{Capítulo 3.}

\subsection{Marco teórico}

La estructura del presente capítulo condensa aquellas categorías conceptuales que ofrecen las bases teóricas, relacionadas con el territorio, comunidad, campesinado, economía rural, comunicación y desarrollo. Así, se parte de la comunicación, porque es el campo sobre el que recae la investigación, siendo el objeto de análisis, seguido del territorio como categoría fundamental de tierras, aunado a las comunidades, cuyas particularidades y características dependen del contexto en que se encuentren.

El campesinado y la economía rural serán dos de los fundamentos conceptuales que van permitir integrar la experiencia socio - comunicativa en el municipio de Ramiriquí para la formalización de tierras la cual se abordará a partir de los objetivos propuestos.

\subsubsection{La comunicación para el desarrollo de las comunidades}

La comunicación y el desarrollo marca la diferencia en el desarrollo humano, dando preferencia a los niveles de comunicación que permiten a cada persona reflexionar y opinar sobre cuestiones importantes para su bienestar; por lo cual la función "en los procesos de crecimiento le distingue de otras formas de comunicación, como por ejemplo las comunicaciones corporativa o interna, y la convierte en parte esencial de los programas dirigidos a alcanzar, de manera equitativa y sostenible, las metas trazadas para la comunidad" (McCall, 2011, pág. 11). 
La comunicación es fundamental en el desarrollo humano, es por eso por lo que los métodos de comunicación son esenciales para aumentar las habilidades de apropiación, por medio de las cuales las personas logran comprender "por sí mismas asuntos, considerar y debatir ideas, negociar y participar en debates públicos de ámbito local y nacional. El papel de la comunicación para el desarrollo en los procesos de crecimiento contribuye a distinguirla de otras formas de comunicación” (McCall, 2011, pág. 13).

Por tanto, la comunicación debe tener un espacio favorable para la proyección e implementación; estos espacios necesariamente tienen que contener normas y leyes que resguarden la libertad de expresión, promuevan el derecho de la ciudadanía a la “información oficial y faciliten la concesión de licencias no discriminatoria a las emisoras de radio locales, así como sistemas de comunicación libres y pluralistas, que impulsen medios de interés de gran calidad para el público en los ámbitos nacional y local” (McCall, 2011, pág. 15).

A partir del año 2000, en un contenido de globalización e internet y como contestación al desarrollo de la comunicación, varios actores en América Latina vienen proyectando un cambio social en la comunicación, "como un nuevo paradigma que intenta construir un auténtico diálogo, estimular la participación, construir ciudadanía, democratizar la comunicación, devolver la palabra y convertir a los sujetos como actores centrales y agentes de su propio desarrollo humano y social” (El Nuevo Diario, 2012, pág. 1).

También es importante saber que para que haya participación en la comunicación por parte de la sociedad tiene que basarse en el conocimiento "(respeto a las lenguas y la historia), busca alianzas y establece redes, y además se define como "la apuesta cultural de cambio, que requiere legitimar y promover una actitud frente a la vida asumiendo el desarrollo como meta personal y colectiva" (El Nuevo Diario, 2012, pág. 1)

Los ciudadanos no son solamente receptores, sino que se han convertido en actores de su progreso, es por esto por lo que por medio de formas de comunicación se permiten hacer parte "en la construcción de su entorno que sirven en la medida en que la cooperación al 
desarrollo facilita el acceso a estas herramientas y promueve el diálogo de igual a igual, también contribuye al empoderamiento de mujeres y hombres" (Jenatsch, T y Bauer, R, 2014, pág. 7).

Por lo tanto, participar en las medidas que perturban el entorno "es un derecho básico y es de suma importancia también en la cooperación para el desarrollo. Los proyectos planificados e implementados con la participación de la población tienen mayor grado de apropiación y en consecuencia son más duraderos y sostenibles" (Jenatsch, T y Bauer, R, 2014, pág. 14). Es así, como las diferentes culturas de comunicación para el desarrollo “y para el cambio social cuentan con una dilatada trayectoria académica y práctica, especialmente en Latinoamérica y en el contexto anglosajón, hasta el punto de conformar una de las disciplinas más veteranas de las ciencias de la comunicación” (Barranquero, 2012, pág. 63), cuya evolución ha tenido una serie de altibajos que se condensan en limitaciones estructurales, las cuales son sencillas de detectar en Organismos y agencias mundiales de cooperación; siempre y cuando, se tenga claridad en las diferencias que existen entre información y comunicación, la cual radica básicamente en que la primera se forma a partir del activismo informativo y las segundas por medio de la formulación de verdaderas políticas y estrategias de comunicación.

De ahí la importancia del significado central de la comunicación para el cambio social, que se basa en procesos dialógicos, en el respeto, la equidad, la justicia social y la participación de las bases que lleva a establecer la necesidad que tienen las autoridades locales en conocer las técnicas y manejo de los medios de comunicación y estrategias comunicativas, a fin de instaurar mecanismos de participación y acción que les permita la toma de decisiones, entendida, como ejercicio del poder; en cuyo caso, la comunicación y la cultura tienen una amplia relación, en cuanto a:

(...) La mirada intelectual aún hegemónica sobre las relaciones entre comunicación y cultura es todavía la que separa y opone el elevado ámbito de la cultura al mundano y mercantil espacio de la comunicación. Un purismo, exacerbado por la banalización de la comunicación y la masiva y perversa mercantilización de los medios, está reconduciendo a hacer de la cultura el desnudo ámbito de lo simbólico, como si ese ámbito no hubiera estado siempre entrecruzado por el oscuro espesor del intercambio 
social que anuda la creación a la producción y al ejercicio del poder (...) (Barbero, 2010, pág. 27).

Es por ello, que el ejercicio comunicativo resulta determinante, desde la perspectiva del imaginario, siempre y cuando éste posea las condiciones particulares, en las que el sujeto desarrolla o expresa su comportamiento comunicante; por medio, de la participación que lleva la interacción del imaginario. Aspecto que se complementa con las distintas "concepciones imaginarias, categorías e instituciones del mundo específicas de una cultura y un momento histórico determinado; en donde, las reglas que rigen la comunicación también son variables según la época y el lugar geográfico” (Dittus, 2006, pág. 11).Lo que permite señalar que el lenguaje resulta ser el requisito sine qua non del pensamiento y la comunicación, a partir del cual se logran los conceptos para comprender el universo; tal como lo señala Dittus (2006) "sin lenguaje no hay conciencia, sin conciencia no hay comunicación, sin ésta no hay realidad significante" (pág. 12).

\subsubsection{El territorio en el dinamismo del mundo actual}

En las últimas décadas en el mundo académico el concepto de territorio ha sobrepasado el componente geográfico, para introducirse con mayor relevancia en otras disciplinas de las ciencias sociales, tales como la sociología, antropología o economía.

(...) esta apropiación del concepto forma parte de los cambios teóricos y conceptuales que desde los enfoques disciplinarios, interdisciplinarios otras disciplinarios ocurren en las ciencias sociales, los cuales buscan explicar la complejidad de los procesos sociales que se dan en la actualidad en un contexto de mundialización de la economía, la cultura y la política; que ha colocado a la dimensión espacial de los acontecimientos sociales en la misma tesitura que la vertiente temporal, la cual va a estar presente en la interpretación de la historia, misma que alcanzó un papel relevante en el estudio de los acontecimientos durante el curso de la época moderna (...)(Llanos, 2010, pág. 207).

Por consiguiente, el territorio es un concepto que ha formado parte del corpus teórico en las diversas vertientes del pensamiento geográfico y el cual, como ya se expresó se ha venido trabajando en diversas disciplinas, con ocasión del proceso de globalización que ha comprometido "las fronteras y los límites territoriales bien definidos geográficamente por 
elementos naturales o humanos, desde el punto de vista tradicional" (González, 2011, pág. 2). En la actualidad la habitual conceptualización de territorio se ha transformado, conforme el mundo ha cambiado. Estableciéndose que éste ayuda en la interpretación y comprensión de las relaciones sociales anidadas a la dimensión espacial; que permite, además, contener las prácticas sociales y "los sentidos simbólicos que los seres humanos desarrollan en la sociedad en su íntima relación con la naturaleza, algunas de las cuales cambian de manera fugaz, pero otras se conservan adheridas en el tiempo y el espacio de una sociedad" (Llanos, 2010, pág. 208).

Aspectos, que permiten abordar el territorio desde el proceso de globalización que según Cuervo (como se citó en González 2011) expresa que en términos generales podría afirmarse que el "interés específico de esta aproximación es el entender las relaciones entre el todo globalización- y las partes -territorio-, teniendo en cuenta las dimensiones económica, política y cultural, de la mano de los vectores de cambio -tecnológico, financiero-" (pág. 7), logrando una conjugación perfecta que hace de la interacción que se da entre globalización y territorio, un concepto sumamente complejo.

Complejidad, que parte del hecho, de establecer que la globalización, en un principio tan alejada de la dimensión territorial, ha supuesto una revalorización del territorio; comprendiendo este no solamente como un "objeto dado, ni el resultado de un proceso; sino como un objeto por hacer, histórico y político y además un objeto de gestión. Entender el territorio implica su descripción, su explicación y el hallazgo de sus ¿qué? y sus ¿por qué?" (Rodríguez, 2010, pág. 8) y porque no de su ¿para qué? que lleva a la dimensión del ¿cómo? y el ¿cuándo? máximo, sí estás tres últimas se tienen en cuenta en el contexto de países con conflictos internos como el que vive Colombia.

Lo expuesto, lleva a abordar el concepto de territorio, en el marco de las Ciencias Sociales y especialmente de la Geografía, que promueven la dinamización de su construcción teórica y práctica, a partir de los análisis de interrelación de los factores biofísicos, humanos y culturales los cuales no escapan a la globalización. 
(...) hablar de territorio implica articular la sociedad porque su relación directa se expresa a través del concepto de territorialidad como pertenencia territorial supeditada a procesos de identificación y de representación colectiva e individual que generalmente desconoce las fronteras políticas o administrativas y no aduce exclusivamente la apropiación espacial estatal o ligada a un grupo de poder (...) (Rodríguez, 2010, pág. 9).

En ese sentido, el territorio no es solamente una porción de tierra delimitada con su complejidad biofísica - relieve, condiciones ambientales, biodiversidad -. Es, sobre todo, "un espacio construido socialmente; es decir, histórica, económica, social, cultural y políticamente" (Sosa, 2012, pág. 7). Además, el territorio se explica y hace referencia a las relaciones entre los seres humanos desde el marco de la espacialidad y lo que la constituye, como, por ejemplo: "las poblaciones, los patrones de asentamiento y producción, movilidad, migraciones, entre otras, que lo convierte en una síntesis humana: valorada, representada, construida, apropiada y transformada" (Sosa, 2012, pág. 10).

De ahí, surgen las microrregiones de las que hacen parte los municipios como Ramiriquí en Boyacá que requieren de organización y apropiación del territorio, que se relacionan sinérgicamente con los ecosistemas, los procesos ecológicos, etc., y que en cierta forma constituyen el objeto de la presente investigación.

Entonces, al concepto de territorio se integra según lo expuesto por Velazco y Molina (2012) citando a Bozzano (2009) quien expresa que el "territorio es el espacio de supervivencia de las comunidades que integra su desarrollo socio cultural y económico, permitiendo la construcción de signos, que interpretan sus contextos y que son necesarios para el desarrollo y reconocimiento de la identidad cultural" (pág. 4).

Por último, el territorio debe ser visto como espacio de articulación para el desarrollo de las comunidades que en éste interactúan; en tal sentido, el territorio aparece como "el resultado de una acción social que, de forma concreta y abstracta, se apropia de un espacio tanto física como simbólicamente" (Velazco, E. y Molina, A., 2012, pág. 4). 


\subsubsection{Comunidades un término inacabado}

Las comunidades, al igual que el territorio están en una constante transformación, buscando validarse al interior de los problemas y situaciones sociales complejas; de modo que la comunidad ha sido comprendida como el "espacio de las relaciones interpersonales cara a cara, los afectos, la cercanía" (Eito, A y Gómez, Q, 2013, pág. 11), que se materializan a través de la sociedad que encierra lo racional, lo moderno y las relaciones que de ésta emergen.

Así, autores como Ander - Egg (1992), Hernández (2009) o Moix (1991 citados por Eito, A. y Gómez, Q. (2013) señalan dos experiencias o categorías importantes: la organización comunitaria y el desarrollo comunitario.

Para fines de la investigación se hace alusión a la organización comunitaria, que contó con iniciativas "como las cajas de comunidad, con el objeto de financiar toda la acción social realizada en una zona geográfica de forma unitaria - superando la dispersión existente a causa del número y la diversidad de agencias sociales -, y los consejos de bienestar de la comunidad" (pág. 12). Este enfoque resulta pertinente, si se tiene en cuenta lo expresado por Moix (1991) citado por Eito, A. y Gómez, Q. (2013) quien estableció que la organización comunitaria, buscó:

(...) la coordinación de las actividades de bienestar social y la cooperación entre las diferentes agencias sociales públicas y privadas, para la elevación y el mantenimiento de niveles de servicio, el desarrollo del liderazgo de la comunidad en la promoción de la salud y el bienestar y la planificación social (...) (pág. 12).

Enfoque muy apropiado al tema de la formalización de tierras en el municipio de Ramiriquí en Boyacá, afianzando que la comunidad es más que la población o el territorio que la contiene y cobija. Por consiguiente, la comunidad en sí encierra tres aspectos claves: Los concernientes a los factores demográficos-territoriales; las relaciones que de ésta emergen contra la exclusión social, y lo referente a comprender la comunidad como motor de cambio en la toma de decisiones y el reforzamiento de la democracia. 
Aspectos que ayudan a comprender la complejidad del término y su carácter multidimensional. Por consiguiente, la comunidad se puede entender como lo señala González (1988) citado por Diéguez, A y Guardiola, A (1998) como un:

(...) modo de relación social, es un modelo de acción intersubjetivo construido sobre el afecto, la comunidad de fines y de valores y la incontestable esperanza de la lealtad, de la reciprocidad; la comunidad es un acabado ejemplo de tipo ideal de la acción social, una construcción teórica de alguna manera extraña de la propia realidad que acostumbra ser algo más sentido que sabido, más emocional que racional (...) (pág. 3).

Modo que requiere una delimitación del espacio que ha sido fijado por criterios políticos, administrativos que se enmarcan en los Planes de Ordenamiento Territorial. Cada "área local tiene características particulares, debido a que son diferentes por ejemplo los recursos físicos - clima, tipo de suelo -, así como las características humanas, cultura y sub - culturas existentes, los valores, junto con las exigencias que provienen de su entorno" (Diéguez, A y Guardiola, A, 1998, pág. 5). De este modo, las comunidades “expresan relaciones recíprocas que tienden a la unidad o más puntualmente a la unión” (Álvaro, 2010, pág. 13).

En el marco de esta concepción resulta pertinente, señalar lo concerniente al aspecto ético que integra el concepto de comunidad. "De relevancia particular para la práctica de la intervención comunitaria, en tanto también aporta a la conceptualización acerca de una meta “ideal” a la cual dirigirse, es la reflexión ética” (Krause, 1998, pág. 58), para el caso el campesinado que pertenece al municipio de Ramiriquí en Boyacá.

Lo expuesto, no se puede terminar sin hacer la debida aproximación a la participación como componente esencial de la comunidad; debido a que permite la interpenetración recíproca de los planos individuales y colectivos, que se sustenta en dos ejes (Causse, 2009, pág. 17):En el contexto social donde tiene lugar y en las relaciones que ocurren en él económicas, políticas, culturales, etc. -, y como proceso entre personas diversas, sus emociones, necesidades e identidades, las cuales dotarán de color propio el proceso de participación en cada ocasión. 
Por último, la pertenencia contribuye con el carácter estructural y funcional que emana de la comunidad, generando un proceso armónico, hacia un fin común, como es la formalización de tierras en el municipio de Ramiriquí en Boyacá.

\subsubsection{Campesinado un concepto lleno de inequidades}

El análisis sobre el campesinado en las últimas décadas se ha ido afianzando, buscando en las diferentes disciplinas una concepción teórica, que en muchas circunstancias aún no ha sido superada; lo cierto es que sigue siendo una constante reconocerlos "como una organización familiar con vida comunal y con un soporte económico de continuidad en la tierra que constituye la base de su relación social como soporte de la unidad del grupo en la vida económica” (Sevilla, E y Pérez, M, 1976, pág. 16).

En el ámbito sociológico el campesinado ha sido comprendido como:

(...) aquel segmento social integrado por unidades familiares de producción y consumo cuya organización social y económica se basa en la explotación agraria del suelo, independientemente de que posean o no tierra y de la forma de tenencia que los vincule a ella, y cuya característica de relaciones sociales se desarrolla en comunidades rurales, las cuales mantienen una relación asimétrica de dependencia, y en muchos casos explotación, con el resto de la sociedad en términos de poder político, cultural y económico (...)(Sevilla, E y Pérez, M, 1976, pág. 29).

De tal conceptualización, se logra establecer que el campesinado es una unidad de reflexión sociológica, en la que se integran varios grupos sociales, cuya naturaleza depende de la posición que ocupen en las relaciones de producción que se dan en los diferentes tipos de organizaciones agrarias. Así, la economía campesina difiere de las demás, por (Shanin, 1979, pág. 13):

- El rasgo distintivo de auto - empleo o más comúnmente llamado trabajo familiar, control de los propios medios de producción, autoconsumo de la propia producción y diversificación ocupacional; 
- Porque las condiciones de vida productiva dependen y están organizadas por el establecimiento de un eco - sistema y un equilibrio especifico de la agricultura, producción animal y labores artesanales;

- Un esquema económico similar a los demás.

Rasgos que lamentablemente en Colombia, "llevan una reiterada invisibilización de la economía campesina, que trata de sobrevivir a pesar de múltiples políticas públicas y proyectos privados que favorecen al agro negocio y la agro exportación" (Chaparro, 2014, pág. 24), así como a usos de los territorios rurales diferentes a los de la producción de alimentos, como la explotación minera y energética.

Situaciones que lamentablemente se enmarcan, en un problema más denso "que es la falta de títulos de propiedad, lo que hace que el campesino no pueda defender la ocupación de hecho de sus tierras" (Ministerio de Agricultura y Desarrollo Rural, 2003, pág. 8).Esto pese a lo establecido en la Constitución de 1991 que establece el mandato de que el Estado debe proporcionar las condiciones necesarias para mejorar los ingresos y la calidad de vida de la población rural pobre y sin tierra.

Posteriormente, la Ley 99 de 1993dispone la protección de las reservas forestales y de las comunidades indígenas; así, como la participación de las comunidades en la colonización de las zonas de frontera agrícola. En el siguiente año, la Ley 160 de 1994 integra lo concerniente a las zonas de reserva campesina y desarrollo empresarial como el principal instrumento que tiene el Estado colombiano para regularizar las áreas de colonización con miras a lograr un mejor acceso a la tierra, mejores servicios y oportunidades de desarrollo para los pobres desposeídos; una participación eficaz delas comunidades rurales en la planeación y ejecución de las tareas de desarrollo. En el contexto de estas dos normas se crea lo que se ha denominado las Zonas de Reserva Campesina - ZRC - que se "configuran como un nuevo enfoque del desarrollo rural, gestionando la solución de los problemas del campo con el aporte participativo y decidido de las comunidades y entidades públicas y privadas" (Ministerio de Agricultura y Desarrollo Rural, 2003, pág. 13). 
Estas normas precedentes de muchas otras son el esfuerzo del Estado por afianzar el desarrollo territorial rural, cuyo enfoque se orienta al análisis del territorio, siendo éste el punto de partida para generar, la "transformación productiva de forma competitiva y sustentable del territorio a mercados dinámicos" (Herrera M, Méndez Y, Tobón G y Sierra A, 2014, pág. 6). Esto con el fin, de afianzar el desarrollo institucional que tiene "el propósito de estimular y facilitar la interacción y la concertación de los actores locales entre sí y entre ellos y los agentes externos relevantes, y de incrementar las oportunidades para que la población pobre participe del proceso y sus beneficios" (Schejtman, A y Bergegué, J, 2004, pág. 4). Sin embargo, es de señalar que la distribución de la propiedad rural del país se ha caracterizado por una gran desigualdad e inequidad.

(...) el alto costo de la tierra, muy por encima de las posibilidades del negocio agropecuario, la segmentación del mercado de tierras, así como el bajo impacto de la acción del Estado para redistribuirla, son algunos de los factores que explican el escaso dinamismo en la redistribución de la tierra y en su traspaso a productores más eficientes. Además, la informalidad en la tenencia de la tierra, que afecta sobre todo a los pequeños productores, dificulta su acceso a otros recursos productivos como el crédito y la asistencia técnica (...) (CONPES 2745, 1994, pág. 3).

Aspecto, que en la actualidad aún no ha sido superado, debido en parte a la falta de información confiable sobre la tenencia; pues hace más de "40 años que no se realiza un censo agrario en muchas regiones del país, por la presión sobre las tierras rurales impuesta por las dinámicas del conflicto armado y el narcotráfico” (Baribbi, A y Spijkers, P, 2011, pág. 15). Adicionalmente, la tenencia de la tierra presenta "bajos niveles de formalidad, alta complejidad y falta de claridad. Esta realidad desestimula la incorporación de los campesinos y colonos, en circuitos económicos formales y dificultan su acceso a los programas del Estado" (Baribbi, A y Spijkers, P, 2011, pág. 16). Situación que dificulta, en sí misma la condición de ser campesino, que en palabras de Wolf (1982) citado por Skerritt (1998) establece:

(...) puede decirse que el campesino se ubica en el centro de una serie de círculos concéntricos. Cada círculo está definido por especialistas con quienes el campesino comparte progresivamente menos experiencias, con quienes mantiene cada vez menos una comprensión mutua. Para decirlo de otra forma: hay quienes están cerca de él campesinos como él-, cuyos motivos e intereses comprende, aun cuando sus nexos con ellos sean completamente tangenciales. Ellos constituyen un nosotros otros, como 
dicen los italianos. Éstos no forman un grupo caracterizado por relaciones sociales duraderas, sino una categoría de gente con quien la interacción y la comprensión son posibles por la base de premisas comunes. Ésta es la categoría referencial positiva del campesino. Con personas que caen dentro de esta categoría pueden desarrollarse relaciones de igualdad. Cada uno buscará su propio beneficio, pero cada uno tendrá conciencia de los límites estrechos más allá de los cuales la persecución del provecho individual amenazará una ruptura de relaciones actuales o potenciales (pág. 6).

También hacen parte del círculo quienes cumplen un papel negativo o de exclusión, de lo que significa ser campesino en conjunto, trayendo consigo las personas o grupos que buscan controlar o afectar los excedentes de la unidad campesina; es decir "los señores o los administradores delos terratenientes, el clero, los oficiales de Estado o los comerciantes" (Skerritt, 1998, pág. 7). Aunque éstos tienen estrecha relación con el ámbito rural, identificándose como actores externos y cuya obligación es dar continuidad a los planes y programas de desarrollo rural, en la realidad resultan ser quienes más afectan la situación del campesinado, por la falta de compromiso en el desarrollo de las políticas en pro de su sostenimiento.

Aspecto que se puede entender mejor, según lo abordado por Wolf (1966) citado por Krantz (1977) quien establecía que el campesino es un productor agrícola, es propietario de la tierra y controla efectivamente el terreno que cultiva y cultiva para su propia subsistencia, aunque venda parte de sus cosechas lo hace para cubrir necesidades cotidianas. Planteamientos que Wolf complementa, cuando señala que los campesinos, "son cultivadores cuyos excedentes son transferidos a grupos dominantes que los utilizan en dos sentidos; para asegurar su propio standard de vida y para distribuir el resto a grupos de la sociedad que no cultivan, pero que deben ser alimentados" (pág. 90).

Entonces, las clases dominantes se han constituido "como una de las generadoras de la concepción y de la praxis social - económica, política e ideológica que considera a los campesinos condenados a desaparecer, acentuando insistentemente las ventajas económicas de la gran empresa capitalista en el campo -" (Martins, 2012, pág. 6). 
Por eso, no es extraño que las ideas en el país sobre el campesinado entran en frecuencia en contradicción con el dinamismo y la heterogeneidad rural, debido a apreciaciones como: “eso es duro pal campesino, que hablan del atraso, de la falta de educación rural, de la vida en el campo y del trabajo con la tierra en términos negativos" (Universidad del Rosario, 2013, pág. 1). La pobreza, la marginalidad, el conflicto y la falta de políticas de desarrollo rural contribuyen a alimentar estos imaginarios urbanos. Imaginarios, que ceñidos a la realidad evidencian la crítica situación de esta población. Así, los habitantes del campo siguen viendo sus necesidades básicas insatisfechas y el nivel de vida experimenta un constante deterioro.

(...) el campesinado en Colombia ha sido históricamente marginado tanto cultural como social y económicamente de los procesos de la sociedad en general. De esta forma, ha sido dominado por grupos que han organizado el territorio, a través de reformas desde el Estado, acorde a los intereses de una elite, en detrimento de las necesidades de la mayoría campesina, agudizando las condiciones de desigualdad y pobreza que confluyen en la marginación de las comunidades desde todos los aspectos (...) (Comunidades campesinas colombianas, 2012, pág. 1).

A pesar de cierta singularidad del término campesino, existe muchas genealogías, “enmarcadas en las relaciones sociales establecidas históricamente por los grupos sociales con otros grupos $\mathrm{y}$, en especial, en relación con el espacio donde dichas relaciones se instituyen" (Tocancipá, 2005, pág. 15). Por ello, el ámbito espacial de la economía campesina se materializa en el territorio, término estrechamente relacionado, al campesinado y no solo en la parcela; por ello, es necesario tener una perspectiva de regulación del uso y del acceso al territorio para entender los conflictos de la economía rural y planificar sus soluciones y así consolidar un concepto en el que cada uno de sus elementos sean determinantes en enaltecer, quizás, uno de los sectores, grupos, miembros, más importantes de las sociedades y de la cual depende en gran parte el desarrollo de las naciones. 


\subsubsection{La economía rural vista desde el desarrollo entre aciertos y desaciertos}

La sociología rural no ha logrado superar adecuadamente el vacío conceptual que quedó después de la desaparición del continuum rural urbano ${ }^{2}$. Así, "lo «rural» como espacio geográfico diferenciado y delimitado, por oposición al «urbano», y como espacio social, ocupado fundamentalmente por grupos agrarios, por oposición a la ciudad compuesta esencialmente de grupos sociales relacionados con la industria o servicios"(García, 1991, pág. 89), responden a construcciones macro sociológicas, que difícilmente, "hoy pueden aplicarse para intentar explicar una sociedad rural y unos sistemas económicos agrarios tan diversificados y tan integrados al mismo tiempo" (García, 1991, pág. 89).

Así, la ruralidad para la Comunidad Económica Europea - CEE - implica no solo "la noción de espacio o delimitación geográfica, sino que se refiere a todo un tejido económico y social que comprende un conjunto de actividades muy diversas: agricultura, artesanía, pequeña y mediana industria, comercio y servicios” (Comisión Comunidad Europea, 1989, pág. 23). Por su parte, para la Organización para la Cooperación y el Desarrollo Económico - OCDE - la palabra rural hace referencia a "los territorios con débil densidad de población y con una actividad económica diversa, relativamente independiente de influencia directa de las zonas metropolitanas" (OCDE, 1988, pág. 13).

Ambas definiciones, muestran una concepción de la ruralidad pragmática, "alejada de planteamientos que impliquen la introducción de variables sociológicas para explicar el entramado de la sociedad rural que ya no aparece como algo opuesto a lo urbano" (García, 1991, pág. 90).

2Es cuando se observa un grado tan amplio de diferenciaciones entre los extremos de comunidades de tipo ideal urbano y rural, que todo asentamiento humano puede colocarse en algún lugar de dicha escala. 
Por ende, puede definirse la economía rural como:

(...) todas aquellas actividades que generan ingresos y empleo a la población rural, permitiéndoles cubrir sus necesidades de alimentación y consumo básicas. A este concepto de economía rural, habría que agregar el supuesto de que la población, tiene acceso razonable - no necesariamente equitativo - a los factores de producción (tierra, capital, trabajo, conocimiento y tecnología) que requiere para desempeñar sus actividades económicas, buscando un cierto equilibrio entre fuerzas económicas en el área rural y evitando concentraciones muy fuertes de recursos como tierra y capital en unos pocos (...) (León, 2006, pág. 3).

Las actividades económicas en el sector rural están estrechamente relacionadas con la producción agrícola, pecuaria y actividades extractivas como la pesca y la industria forestal. "Dichas actividades son realizadas por personas que viven físicamente en áreas rurales o que dependen para sus ingresos de actividades desarrolladas allí, aunque no residan de manera permanente en éstas" (León, 2006, pág. 3).Se entiende, que la ruralidad ha sido aunada al concepto de desarrollo rural, aspecto que se aborda a continuación, no sin antes, presentar una sucinta definición de desarrollo:

(...) el concepto de desarrollo ha evolucionado de una visión económica e instrumental a una concepción más integral y humana. Así, las políticas del desarrollo hoy apuntan a fortalecer la capacidad de las personas y favorecer procesos de investigación y desarrollo que mejoren la tecnología, el capital humano y el crecimiento. El crecimiento y el desarrollo son campos de construcción teórica y de múltiples controversias, pero en esencia son temas políticos. Toda sociedad democrática, pese a sus imperfecciones, procura la libertad, la equidad y la participación de los ciudadanos, respeta los derechos humanos y se preocupa por la inclusión social (...) (Albán, 2011, pág. 329).

Abordado lo anterior, se tiene que el desarrollo rural tiene su origen en Europa, en los ideales de desarrollo económico común, lo que lleva a Europa a unir sus esfuerzos, cristalizándose en la firma del Tratado de Roma, 25 de marzo de 1957.

(...) durante la primera etapa de creación de la UE, el desarrollo rural no va a ser sino una parte de desarrollo económico de la comunidad, lo que supone, -considerado desde la actualidad- una limitación al contenido plural que encierra el concepto de desarrollo.

Un segundo momento comienza con el Plan Mansholt, (18 de diciembre de 1968) sobre modernización de estructuras agrarias, encaminado entre otros objetivos a paliar el elevado coste de mantenimiento de los excedentes agrarios, proponiendo una serie de medidas de carácter socio estructurales (...)(Nogales, 2006, pág. 10). 
Se une a los esfuerzos realizados en la materia, el Tratado de Maastricht (1992) en el que se señaló la necesidad de contribuir en la disminución de diferencias entre las diferentes regiones de los Estados miembros, buscando la "la cohesión económica y social reduciendo las diferencias entre los niveles de desarrollo de las diversas regiones y el retraso de las regiones menos favorecidas, incluidas las zonas rurales" (Artículo 130 A), a través de políticas económicas mediante los Fondos de finalidad estructural como el Fondo Europeo de Orientación y de Garantía Agrícola (130 B).

De lo expuesto, se deduce la evolución de la idea de Desarrollo Rural en la Unión Europea, que además integra cuatro variables determinantes en su proceso de formación, las cuales son: las políticas, ambientales, urbanas y sociales, todas vistas o analizadas desde el contexto económico que resulta determinante e inherente a cada una de éstas.

Entonces, el concepto de economía rural emerge como la necesidad de contar con una “economía rural saneada basada fundamentalmente en el mantenimiento de un gran número de pequeñas propiedades, de tal manera que además de proteger el espacio, garantice la conservación de la estructura social de las economías rurales” (Nogales, 2006, pág. 10).

Se percibe de lo enunciado, el carácter de la pluralidad política del desarrollo rural, gracias a la incidencia de la Política Agraria - la Política Medioambiental en el contexto de la diversidad de las zonas rurales. Por consiguiente, la Unión Europea no busca la uniformidad del campo y la ciudad, sino establecer zonas rurales dinámicas cuyos habitantes participen del bienestar general; sin que ello, suponga la pérdida de diversidad regional y cultural europea. Es decir, "el desarrollo rural implica, entre otras características fundamentales, el que los agentes locales tomen la iniciativa y participen activamente en su propio desarrollo" (Nogales, 2006, pág. 12).Ya, en el contexto latinoamericano el desarrollo rural tiene dos enfoques, uno moderno y uno tradicional.

(...) el moderno generalmente está conformado por la ciudad o ciudades más grandes, en donde, se concentra la actividad económica de la nación. La actividad económica a su vez se basa en las actividades del sector comercial (incluyendo el mercado interno y las exportaciones y las importaciones), del sector de la gran agricultura y del sector 
minero. El sector tradicional se compone de la agricultura campesina y de las comunidades nómadas y sus también transitorias prácticas económico/culturales (...) (Castillo, 2008, pág. 21).

Así, las cosas, en Latinoamérica el sector moderno funcionaría como un enclave económico separado del sector tradicional.

(...) llevando, entonces a establecer que la pobreza de estos países se podía explicar, dada dicha separación y la preponderancia del sector tradicional sobre el moderno, especialmente en términos del número de habitantes en el sector rural/tradicional. Consecuentemente, el paradigma de la economía dual identifica una serie de prescripciones sobre qué hacer para que dicho sector tradicional se modernice (...) (Castillo, 2008, pág. 12).

Ya, en el proceso de industrialización con la llegada del neoliberalismo, se dio la "sustitución de importaciones que duró alrededor de tres décadas - 70, 80 y 90 -, y fue remplazado por el modelo neoliberal que se aplica de manera generalizada en todos los países que antes se denominaban en vías de desarrollo, y que bajo este esquema se llaman emergentes" (Castillo, 2008, pág. 21).

Entonces, desde la perspectiva neoliberal, el desarrollo rural se ha identificado como la estrategia para atender a los pobres rurales, quienes se convirtieron en parte de una política territorial, de una política de desarrollo local, conjugándose lo urbano y lo rural. Por consiguiente, el desarrollo rural supone: primero una visión global de la sociedad nacional; segundo establecer diferencias entre el desarrollo rural y agrario; tercero un entendimiento del mundo campesino, entre otros.

En la materia, existen un sinnúmero de conceptos que se han ido modificando conforme el mundo ha ido evolucionando; por ello, se suma los planteamientos realizados por la academia colombiana, en las voces de Pérez y Farah (2002) que indican que en el desarrollo rural en América Latina, se ha hecho énfasis en la mitigación de la pobreza, a través de un concepto de sostenibilidad no solamente en recursos naturales, sino en lo económico, político, social y cultural que incorporan el "concepto de empoderamiento de las comunidades campesinas, en la búsqueda de que los pobladores rurales y las distintas 
organizaciones se doten de poder para que puedan ejercitar sus derechos frente al Estado" (pág. 13).

Postura, que integran los elementos de supervivencia que ha caracterizado el desarrollo rural, de cara a la interacción con los centros urbanos, sin importar si son grandes o pequeños, unidos a la idea de oportunidades que busca es "desarrollar las potencialidades de los pobladores rurales" (Pérez y Farah, 2002, pág. 15).

De modo que, en el desarrollo rural resulta determinante las reformas agrarias, cuyo concepto es abordado por Machado (2013) citando lo expuesto por Dorner (1972) quien la define como "todos los cambios sustanciales y deliberados en el régimen de tenencia de la tierra, o sea, en la propiedad y control de los recursos de tierra y agua" (pág. 15). Se suma, a la anterior definición, lo expuesto por García (1967) citado por Machado (2013) quien señalaba:

(...) también ha sido entendida como "una estrategia de modificación y sustitución de la estructura agraria tradicional, por medio de un repertorio de factores: la redistribución de la tierra, los ingresos y el poder político; la formación de un nuevo sistema de empresa, racional e intensivo, diseñado de acuerdo al marco real de los recursos y de los objetivos estratégicos del desarrollo; la apertura a una estructura social fluida, móvil, dinámica y de clases abiertas; la integración cultural y política de las masas campesinas y la articulación de este gigantesco proceso de cambio a la estrategia general de desarrollo de la sociedad latinoamericana (...) (pág.15).

Concepto que ha llevado a establecer que las reformas agrarias, se pueden dividir en estructurales, convencionales y marginales, según el grado de transformación de la estructura agraria. En cuyo caso, la política de tierras, se entiende como el "manejo del recurso tierra y los factores de producción que le son complementarios - agua, capital, medio ambiente -, sin llegar a tocar directamente, como objetivo sustancial, las relaciones de poder construidas sobre la tenencia de tierra” (Machado, 2013, pág. 17).De esta forma, el concepto de desarrollo rural en el contexto colombiano ha sido tomado con enfoque territorial, recogido en el proyecto de ley presentado por el Ministerio de Agricultura y Desarrollo Rural (2011). 
Finalmente, el desarrollo rural debe ser comprendido como un proceso dinámico que ayuda a la transformación de las sociedades rurales y locales, gracias a la participación de diferentes actores sociales, permitiendo el desarrollo de actividades productivas y la generación de ingresos, a través de la organización social y la participación política.

\subsubsection{El desarrollo como pilar de crecimiento, desde un contexto comunitario}

El desarrollo de la comunidad hace parte del concepto más amplio, general y complejo del desarrollo que como cualquier otro concepto, hace referencia a "una construcción social e histórica, que siempre es resultado de una historia social, cultural y material" (Carvajal, 2011, pág. 27).

Así, el desarrollo de la comunidad es comprendido como "el proceso destinando a crear condiciones de progreso económico y social para toda la comunidad, con la participación activa de ésta, y la mayor confianza posible de su iniciativa” (Carvajal, 2011, pág. 38).Aspecto que debe tenerse en cuenta o que no debe olvidarse desde ningún punto de vista puesto que, en sociedades complejas, pluriétnicas y multiculturales como la colombiana, no es factible que el Estado asigne o generalice aspectos políticos, sociales, culturales y de bienestar para todas las personas, sin tener en cuenta las diferencias entre ellas.

El desarrollo, al igual que los demás términos abordados en la presente tesis, tienen diferentes corrientes - filosóficas, sociales, psicológicas, económicas - las cuales no son el objeto específico del estudio; razón por la cual, se aborda el concepto desde la parte humanística y en el contexto de las comunidades. Por ende, el Programa de las Naciones Unidas para el Desarrollo (en adelante PNUD), desde 1990, ha establecido la siguiente definición sobre desarrollo humano:

(...) el desarrollo humano significa aquí, tanto el proceso de ampliar las oportunidades de los individuos como el nivel de bienestar que han alcanzado. También, ayuda a 
distinguir claramente entre dos aspectos del desarrollo humano. Uno es la formación de capacidades humanas tales como un mejor estado de salud o mayores conocimientos. El otro es la forma como los individuos emplean las capacidades adquiridas, ya sea para el trabajo o el descanso (...) (Programa de las Naciones Unidas para el Desarrollo [PNUD], 1990, pág. 38).

Lo que se logra interpretar del concepto "es que el cambio en las condiciones económicas y sociales es deseable únicamente si se mejora la calidad de vida, entendida como las oportunidades de las personas para decidir cómo vivir sus vidas” (Mujica, Ch y Rincón, G, 2010, pág. 313). Aspecto que sirve para el tema de la tenencia de la tierra de los campesinos en el municipio de Ramiriquí en Boyacá; en tanto en cuanto la calidad de vida de estas personas se ve mermada dadas las actuales circunstancias, esto es el desconocimiento que tienen sobre el derecho a tener en propiedad sus tierras.

Entonces, el desarrollo debe ser comprendido desde las particularidades del contexto; por eso se debe hacer referencia a que "el desarrollo no consiste simplemente en lograr hoy que todo el mundo viva como los países desarrollados. Eso es sencillamente imposible, porque el planeta no lo permite, no existen hoy condiciones naturales para ello" (Bertoni, Castelnovo, Cuello, Fleitas, Pera, Rodríguez y Rumeau, 2011, pág. 10). Desde este punto de vista, el desarrollo se debe concebir desde el diseño e implementación de objetivos comunes. 


\section{Capítulo 4}

\subsection{Diseño metodológico}

\subsubsection{Enfoque epistemológico hermenéutico interpretativo}

Para la presente investigación, asumí el enfoque hermenéutico - interpretativo; en ese sentido, la hermenéutica se entiende como como una actividad de reflexión, que permite la interpretación orientada a facilitar el pleno entendimiento de los textos en los diferentes contextos por los que ha atravesado la humanidad. De ahí que, la capacidad interpretativa de la hermenéutica ayuda en el análisis de una obra descubriendo todo lo que en ella se infiere, en cuanto, a su género y estilo. Así, Arráez, Calles y Moreno (2006) citando a Gadamer (1995) expresan que este autor busca demostrar cómo la hermenéutica, indica no sólo el procedimiento de algunas ciencias, o el "problema de una recta interpretación de lo comprendido, sino que se refiere al ideal de un conocimiento exacto y objetivo, pues el comprender no es una de las posibles actitudes del sujeto, sino el modo de ser de la existencia como tal" (pág. 177).

\subsubsection{Metodología: cualitativa}

La metodología cualitativa, tiene como objetivo la descripción de las cualidades de un fenómeno que abarca parte de la realidad de un objeto de estudio. No se trata de probar o de medir en qué grado se encuentra una cierta cualidad, sino de descubrir tantas cualidades como sea posible que describan el fenómeno. 
El alcance final de los estudios cualitativos generalmente consiste en comprender un fenómeno social complejo, en este caso un socio - político - económico. "El punto está en comprender el fenómeno y no en medir las variables involucradas en dicho fenómeno" (Hernández S, Fernández C y Baptista L, 2010, pág. 117).

\subsubsection{Método: Estudio de caso}

La investigación se sustenta en un estudio de caso único que "tiene como particularidad básica abordar de forma intensiva una unidad, ésta puede orientarse a una persona, una familia, un grupo, una organización o una institución” (Stake, 1994, pág. 239). Puede ser algo simple o complejo, pero siempre una unidad. Así, el estudio de caso como un enfoque se sitúa en un paradigma, "lo que significa una postura general frente a la existencia misma y la forma de ubicarse con respecto al conocimiento. Los estudios de caso pueden ser abordados como parte integral de un enfoque como el cualitativo" (Muñiz, 2003, pág. 2).

Esta investigación se basa en el caso que corresponde al programa piloto de formalización de tierras en el municipio Ramiriquí - Boyacá, 24 veredas, 9.926 personas, y 2.755 predios para legalizar, en el periodo de un año 2014 y 2015.

Proceso que se inició con el número de predios registrados por el Instituto Geográfico Agustín Codazzi que a 2014 eran 8.260, estableciéndose que para el periodo en estudio se hicieron 2.755 solicitudes de formalización, conforme lo señaló el Ministerio de Agricultura (2014). Datos que constituyen la base para el estudio de caso.

(Véase figura 1). 


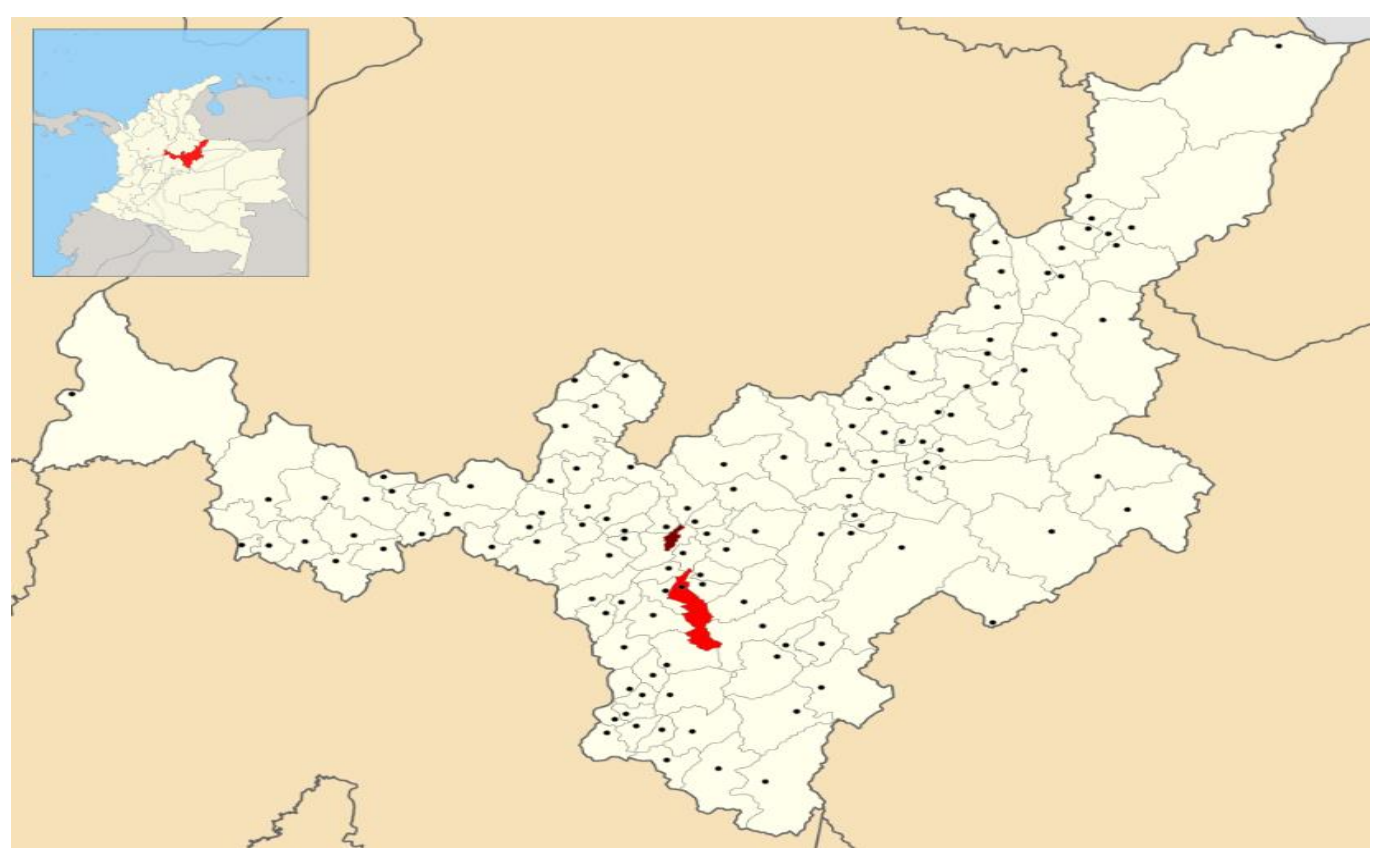

Fuente: Google mapas (2017)

\subsubsection{Técnicas de investigación}

El desarrollo metodológico se realizó con la aplicación de dos instrumentos:

- La guía de observación: Observar, "en el lenguaje corriente apunta a mirar y estudiar algo detenidamente, concentrando la atención en aquello que se busca conocer directa o indirectamente, siendo la segunda aquella en la que el investigador se dirige al grupo para obtener la información deseada" (Martínez, 2011, pág. 26); en cuyo caso la guía de observación aporta los elementos necesarios debido a que permite el manejo de un cuestionario previo que ayude a la búsqueda de la información deseada. Es una técnica que se basa en la utilización de los sentidos para captar cualquier suceso o situación referente a la investigación en desarrollo" (Peñaloza, A y Morella, O, 2005, pág. 7), "la cual debe "precisar lo que se va a observar; categorizar lo que se desea observar, ubicar los aspectos que se van a observar en la dimensión deseada -el problema y objetivo general-" (Peñaloza, A y Morella, O, 2005, pág. 28). 
Se escogió la guía de observación, debido a que está técnica permite que los hechos sobresalientes sean debidamente registrados. La guía de observación permitió anotar los elementos que el investigador buscó observar, haciendo una debida formulación de los mismos; la importancia de esta técnica radicó en el registro de situaciones auténticas de lo que se observó (Véase anexo A).

- Entrevista semiestructurada: "La entrevista es simplemente la comunicación interpersonal establecida entre el investigador y el sujeto de estudio con un determinado propósito. Es una relación que tiene por objeto obtener respuestas verbales a los interrogantes planteados sobre el problema propuesto” (Peñaloza, A y Morella, O, 2005, pág. 28). La entrevista es básicamente cualitativa porque el entrevistado tiene más posibilidades de expresión, lo que le permite comprender más los puntos de vista, actitudes, impresiones, puntos de vista, entre otros; es una forma de hacer investigación a profundidad. Dentro de los tipos de entrevista existentes, se encuentra la semiestructurada y esquemática, la cual parte de una "guía de preguntar con los temas o elementos claves que se quieren investigar o profundizar de una exploración previa con el informante. Las preguntas pueden ser planteadas de diferente forma, significa que no hay secuencia en el orden de la pregunta" (Peñaloza, A y Morella, O, 2005, pág. 30). En la entrevista se realizaron preguntas abiertas que sirvieron de orientación para percibir más matices de la respuesta, la cual exigió gran atención del investigador para no perder el cauce del tema a tratar (Véase anexo B).

Así, las actividades a desarrollar se realizaron por objetivos, con el fin de dar respuesta a la pregunta de investigación y generar la propuesta de solución para la formalización de tierras en el municipio de Ramiriquí - Boyacá; para ello, se estableció el siguiente desarrollo metodológico (Véase tabla 1). 
Tabla 1. Desarrollo metodológico

\section{OBJETIVOS}

ACTIVIDAD

Analizar la estrategia socio-comunicativa que se utilizó en el proyecto formalización de tierras en Ramiriquí Boyacá, propuesto por el Ministerio de Agricultura en el marco del desarrollo y cambio social.

Identificación de problemas centrales, sus causas y sus efectos, a través de la guía de observación (Véase anexo A).

\begin{tabular}{|c|c|}
\hline $\begin{array}{l}\text { Identificar la estrategia socio } \\
\text { comunicativa que se implementó en el } \\
\text { proyecto de formalización de tierras en } \\
\text { Ramiriquí Boyacá. }\end{array}$ & $\begin{array}{l}\text { Para cumplir este objetivo se realizaron ocho (8) } \\
\text { entrevistas a funcionarios de diferentes entidades: } \\
\text { Alcaldía municipal, Ministerio de Agricultura, } \\
\text { Oficina asesora de Planeación e infraestructura, } \\
\text { Personería, Dirección Administrativa Unidad de } \\
\text { Servicios públicos y Policía Nacional (Véase anexo } \\
\text { B). }\end{array}$ \\
\hline $\begin{array}{l}\text { Analizar el alcance de la estrategia socio - } \\
\text { comunicativa, utilizada en el municipio de } \\
\text { Ramiriquí para la formalización de tierras. }\end{array}$ & $\begin{array}{l}\text { Objetivo que se desarrolla a partir de lo dispuesto } \\
\text { en el marco teórico. }\end{array}$ \\
\hline $\begin{array}{l}\text { - Establecer los logros y dificultades en la } \\
\text { implementación de la estrategia socio } \\
\text { comunicativa propuesta por el Ministerio de } \\
\text { Agricultura en el municipio de Ramiriquí - } \\
\text { Boyacá }\end{array}$ & $\begin{array}{l}\text { Objetivo que se desarrolla a partir de lo dispuesto } \\
\text { en el marco teórico y los hallazgos en el análisis de } \\
\text { la estrategia socio - comunicativa }\end{array}$ \\
\hline
\end{tabular}

Fuente: elaboración propia.

De este modo, para desarrollar el objetivo general se realizó la compilación y análisis de la información secundaria relacionada con el contexto que para el caso es el municipio de Ramiriquí, también se realizó la guía de observación, mediante la cual se buscó identificar los problemas centrales con sus causas y efectos. En el abordaje de los objetivos específicos, 
en cuanto a identificar las generalidades del proceso de formalización de tierras se llevaron a cabo las entrevistas a los funcionarios de las diferentes entidades municipales.

Para determinar las herramientas socio - comunicativas se hizo alusión a la metodología para la formalización masiva de la propiedad rural por barrido predial, utilizada por el Ministerio de Agricultura (2013) propuestas en el municipio de Ramiriquí y finalmente se generó el análisis, a partir de todo el hallazgo, mediante el cual se identificaron los actores claves en el proceso, y se diseñaron los sociogramas o mapas de actores.

Todo lo señalado se puede apreciar en el capítulo de resultados. 


\section{Capítulo 5.}

\subsection{Resultados}

\subsubsection{Contexto}

Ramiriquí municipio del departamento de Boyacá, ubicado al sur oriente del mismo, tiene más de quince mil habitantes entre el sector urbano y rural; este "municipio recibe su nombre gracias al último Caciquemuisca de la región - quien fuera llamado Ramiriquí; adicionalmente fue la cuna de José Ignaciode Márquez, primer presidente civil de Colombia” (Alcaldía de Ramiriquí - Boyacá, 2016, pág. 1).

(...) El Municipio de Ramiriquí se encuentra ubicado geográficamente en la Provincia de Márquez, con una extensión de $139 \mathrm{Km} 2$, que comprenden sus 24 veredas y el casco urbano. las veredas son: Rosal, Potreros, Pabellón, Peñas, Santana, Resguardo Alto, Resguardo Bajo, Faravita, Caicedos, Romazal, Santuario, Fernández, Fragua, Gachacavita, Naguata, Hervideros, Común, Pantano Largo, Guacamayas, Farquentá, Escobal, Hortigal, Chuscal y Guayabal dentro del territorio de Ramiriquí se encuentran los centros poblados de Fátima en la vereda Guayabal y San Antonio en la vereda Chuscal que fueron inspecciones de policía. Como capital de provincia le hace importante frente al desarrollo no solo de su territorio, también de su provincia, proyectándose a la fecha como un polo de desarrollo económico, social, cultural y político. (Alcaldía de Ramiriquí - Boyacá, 2016, pág. 1)

Entre sus límites colinda por el norte con Tunja, capital del departamento de Boyacá; ciudad con la cual mantiene sus principales relaciones comerciales y económicas y por medio de ellas la conexión con Bogotá, D.C. para el mismo fin; por el sur sus límites son con los municipios de Chinavita y Zetaquirá; este último también colinda por el oriente, así como Rondón y Ciénaga; finalmente hacia el occidente con los municipios de Chivata, Tibana y Jenesano. A continuación, se puede observar en la figura 2 el mapa del municipio de 
Ramiriquí ubicado en el marco del departamento de Boyacá, con sus límites tal como fueron descritos anteriormente.

Figura 1. Mapa del municipio de Ramiriquí.

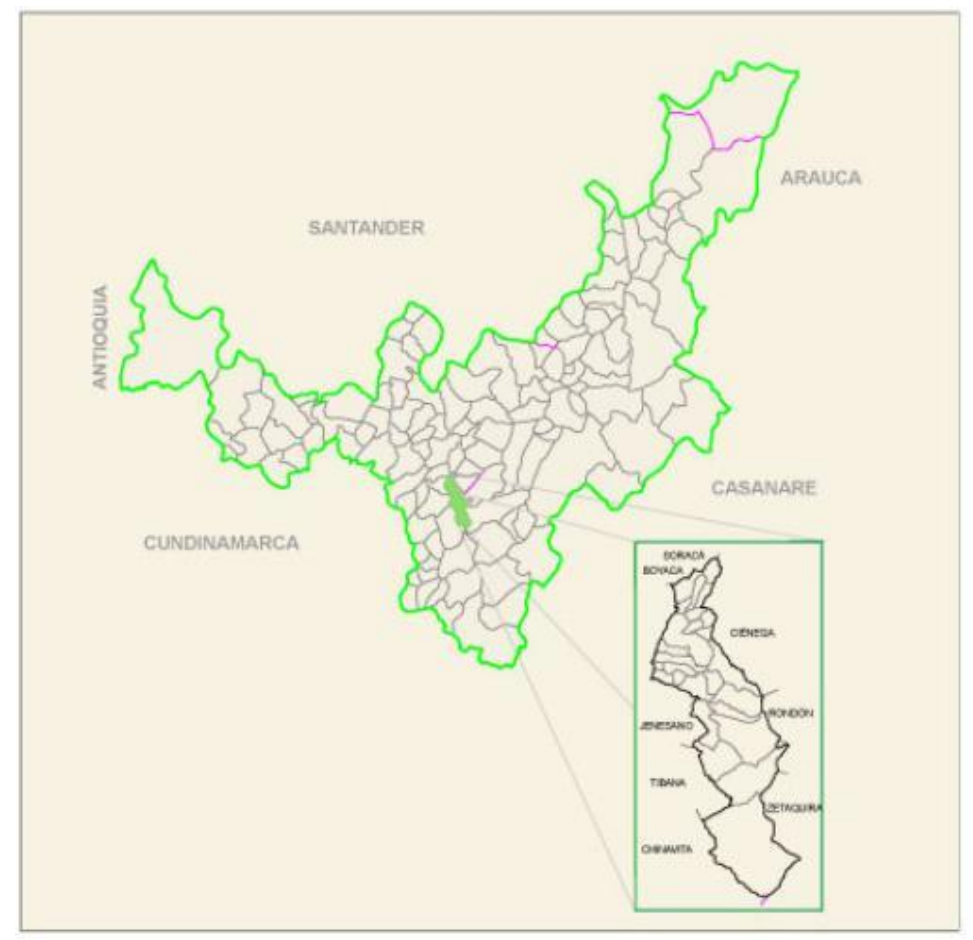

Fuente: Alcaldía de Ramiriquí- Boyacá (2016)

Las principales fuentes de ingresos del municipio están dadas por el concepto de la agricultura y en una pequeña porción por la pequeña industria, en el sector del agro se destaca principalmente el cultivo de:

(...) frutales como la uchuva, tomate de árbol, pepino, alverja, fríjol, maíz, mora entre otros cultivos, hacen del municipio de Ramiriquí un municipio agrícola por excelencia. Otras de las actividades generadas dentro del sector primario son las actividades pecuarias, la pesca, la silvicultura y la ganadería que ocupa un área porcentual de 3659 Ha16 correspondiente a un $29.2 \%$ del territorio y un $20.5 \%$ lo ocupa la agricultura.

La base de la economía del municipio es la agricultura siendo está un potencial para el desarrollo del municipio de Ramiriquí, más exactamente la población del área rural. (...) (Alcaldía de Ramiriquí - Boyacá, 2016, pág. 1) 
En el marco de esta fuente principal de ingresos es que se ha desarrollado el proyecto de legalización de predios rurales carentes de títulos legales, programa impulsado desde el gobierno nacional en coordinación y dirección directa del Ministerio de Agricultura, pues:

La informalidad en la tenencia de predios rurales, es decir, la ausencia de títulos sobre el terreno válidamente registrados es una de las problemáticas que afecta al sector rural de nuestro país, es tanto así, que el $48 \%$ de los predios rurales inscritos en el catastro Nacional no cuenta con títulos correctamente registrados. El Ministerio de Agricultura y Desarrollo Rural MADR indica que: El fenómeno afecta los mercados de tierras, la producción agropecuaria, la inversión pública rural y la asignación de los recursos en el campo por lo cual el problema trasciende el ámbito individual y se convierte en un asunto de interés y conveniencia públicos. La formalización de la propiedad rural se revela, entonces, como una inversión que revierte en mayores ingresos rurales privados y públicos, mayor acceso de la población campesina a la propiedad de la tierra, uso más racional de ésta y mayor gobernabilidad en el campo (Alcaldía de Ramiriquí, 2014).

Al respecto, el Ministerio de Agricultura y Desarrollo Rural, en conjunto con la Secretaría de Fomento Agropecuario, informaron que cerca del " $70 \%$ de los predios rurales en Boyacá que corresponden a 380.000 figuran bajo el título de informalidad, y procuran seguir avanzando en el proceso de legalización de dichos terrenos" (Gobernación de Boyacá, 2015). Situación que ha ocasionado, que el programa que inició hace tres años, no tenga la incidencia deseada, pese a los esfuerzos realizados a comienzo de éste. Esto significa que en Boyacá y en especial en el municipio de Ramiriquí los predios con características de microfundios, minifundios, y falsa tradición no tengan acceso a los servicios del Estado, correspondientes a los financieros, públicos y de oferta institucional.

Así, en su momento existió una partida de \$40.000 millones de pesos para iniciar el proceso de formalización, pero que no han sido desembolsados porque no existe la "institucionalidad tanto administrativa como jurídica para instrumentar estos recursos, tampoco existe la metodología para enfrentar las diferentes fases y etapas que se deben surtir para llegar hasta la disposición por parte de cada uno de los beneficiarios del programa" (Gobernación de Boyacá, 2015) a través del cual se construyó el proceso conforme la metodología para la formalización masiva de la propiedad rural por barrido predial propuesta por el Ministerio de Agricultura (2016). Partiendo del proceso de gestión que es sobre el cual recaen las acciones comunicativas, formando una cadena hasta llegar al destinatario final; es decir, el 
sector rural donde se encuentran los campesinos y por obvias razones las tierras para ser formalizadas

Finalmente, este programa que llega al municipio desde el 2012, con ayuda del departamento y la alcaldía municipal de la época buscaba la formalización inicial de cerca de dos mil ochocientos predios, por medio de un proceso de tres etapas y en 12 pasos, los cuales fueron descritos anteriormente; que reúne componente tanto sociales, económicos y jurídicos. De ahí que, la propuesta socio-comunicativa en el proyecto de formalización de tierras, tuvo un fuerte impulso en sus orígenes, como se ha evidenciado en la presente investigación; esto gracias a la estrategia masiva de comunicación y difusión en el lanzamiento de la iniciativa por parte del gobierno nacional en cabeza del Ministerio de Agricultura, la gobernación de Boyacá y el municipio de Ramiriquí.

\subsubsection{Identificación de la estrategia socio - comunicativa que se implementó en el proyecto de formalización de tierras de Ramiriquí - Boyacá.}

La estrategia socio - comunicativa hace parte de la guía metodológica de formalización masiva por barrido predial propuesta por el Ministerio de Agricultura (2012), siendo la base fundamental para la caracterización de la estrategia. Es importante establecer que la estrategia de comunicación se formuló en el año 2012, año en el cual se dio inicio a la primera fase sobre la formalización de tierras, por lo cual su alcance fue informativo y de acercamiento a las comunidades rurales y autoridades locales.

En este orden de ideas la metodología propuesta hizo énfasis en:

La participación de las comunidades en las diferentes etapas del proceso, el cual se inició con jornadas de socialización y capacitación colectivas que involucraron a los actores sociales del municipio y específicamente a los líderes comunitarios de las veredas a intervenir. Se socializo ante la comunidad los beneficios de la formalización 
y el alcance del Programa en cada Zona de Formalización Masiva y se invitó a los habitantes a participar en las jornadas que se realizaron en cada vereda para que realizarán la presentación de solicitudes personalmente y aportarán sus documentos. El enfoque poblacional privilegió a la población rural vulnerable y especialmente a las mujeres (Ministerio de Agricultura y Desarrollo Rural, 2012a, pág. 13).

Es así, como tras dos años de ejecución - 2012 /2015 del programa, a través de la Ley 1561 de 2012, promovido desde el gobierno nacional, pero incentivado desde el Ministerio de Agricultura, se han podido estandarizar diferentes datos en torno a las solicitudes de Formalización de sus predios. A través de los grupos técnicos de formalización municipal (GTF) en cada municipio, en Ramiriquí para el 2014, se había registrado los siguientes datos:

Tabla 2. Solicitudes de Formalización de Propiedad Rural

\begin{tabular}{|l|l|l|l|l|}
\hline Municipio & Predios IGAC & Mejoras Inscritas & $\begin{array}{l}\text { Solicitudes } \\
\text { Formalizar }\end{array}$ & $\begin{array}{l}\text { Predios en } \\
\text { solicitudes }\end{array}$ \\
\hline Ramiriquí & 8.260 & 210 & 2.755 & 643 \\
\hline
\end{tabular}

Fuente: Programa de Formalización Ministerio de Agricultura (2014).

Como se puede observar en la tabla 2 existían 2755 solicitudes de formalización en 2014, número de acuerdo con el registro de Catastro que incluyen mejoras o posesiones de terceros en predio ajeno. Las mejoras, hacen referencia a predios sin formalizar.

Así, en lo referente al municipio en estudio se recibieron los predios antes mencionados, de los 8260 registrados ante el Instituto Geográfico Agustín Codazzi, los 210 corresponden de acuerdo con lo que establece el Ministerio de Agricultura a los predios sin formalizar, que se pueden apreciar en el mapa que se muestra a continuación: 
Figura 2. Mapa de Formalización de Propiedad Rural de Ramiriquí.

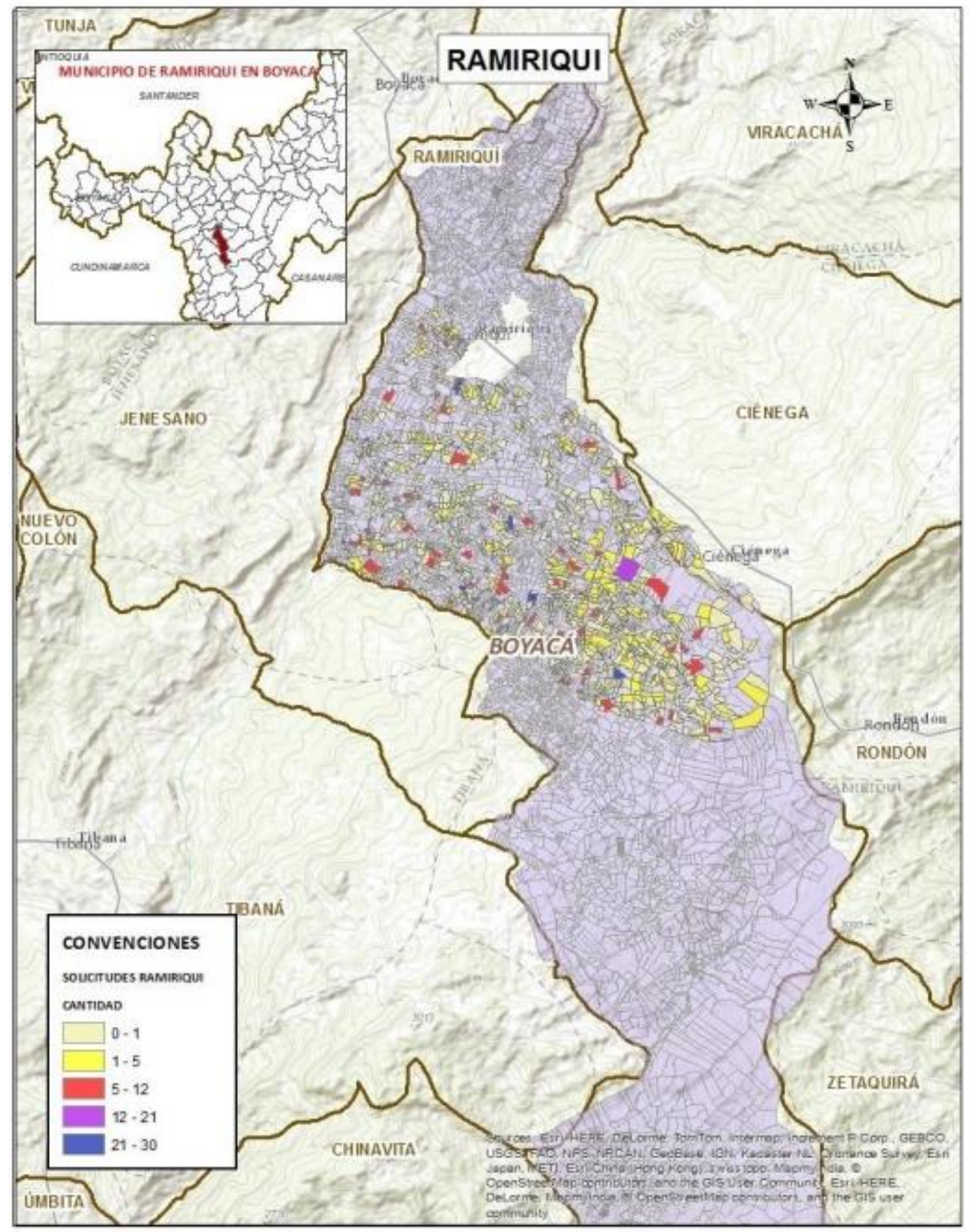

Fuente: Programa de Formalización Ministerio de Agricultura, 2014. 
Con relación a lo propuesto por el Ministerio de Agricultura, en cuanto a la formalización de predios, no se cuenta con un consolidado de los avances hechos en la materia; por cuanto, aducen depender del Ministerio para oficializar el registro que la Alcaldía lleva, que de forma informal según la visita realizada no suman más de mil doscientos predios a 2014.

Sin embargo, es importante resaltar que la estrategia socio - comunicativa realizada entre el año 2012 - 2015 constituyó el punto de partida para comenzar el proceso de formalización, que con el tiempo ha logrado algunos resultados importantes, como lo señala la Agencia Nacional de Tierras - ANT -, a través de noticias Caracol (2017) que informo que en Ramiriquí se entregaron 176 títulos de propiedad, siendo mujeres el mayor número de beneficiarios que ahora cuentan con la propiedad a su nombre. "En total fueron 102 mujeres y 74 hombres, los que desde 1970 luchaban por obtener un documento que validara la propiedad de esas tierras" (Caracol Radio, 2017, pág. 1). Entrega que se realizó en la celebración del día del campesino.

Resultados que permiten establecer que el ejercicio comunicativo como finalidad de la democracia, ayuda en la construcción de la sociedad y a su vez la comunicación permite fortalecer los procesos de participación de los diferentes actores sociales - gobierno campesino - , para lo cual es importante "incorporar procesos de información pública que competen al bien común, al bien público, movilización social hacia la construcción de lo público" (Rodríguez, Obregón y Vega, 2002, pág. 21), de cara al desarrollo; en donde, la naturaleza colectiva del proceso como la que se evidencia con la formalización de tierras se enfrenta al hecho de que el conflicto es propio de las sociedades humanas; razón por la cual, los intereses contrapuestos o concepciones diferentes, en "cuanto a cuál es el escenario que se desea alcanzar o cuál es el camino más adecuado para alcanzarlo pueden constituirse en obstáculos insalvables para implementar un proyecto de desarrollo"(Bertoni, Castelnovo, Cuello, Fleitas, Pera, Rodríguez y Rumeau, 2011, pág. 81).

En este orden de ideas, el desarrollo se concibe cuanto existe un consenso mínimo acerca de ciertas decisiones políticas, como el caso de la formalización de tierras. 


\subsubsection{Análisis del alcance de la estrategia socio - comunicativa utilizada para la formalización de tierras en Ramiriquí - Boyacá.}

La estrategia socio - comunicativa de la formalización de tierras tiene su importancia en el papel que tiene "la comunicación para el desarrollo en los procesos de crecimiento, gracias a que contribuye a distinguirla de otras formas de comunicación” (McCall, 2011, pág. 13), teniendo como paradigma "que intenta construir un auténtico diálogo, estimular la participación, construir ciudadanía, democratizar la comunicación, devolver la palabra y convertir a los sujetos como actores centrales y agentes de su propio desarrollo humano y social" (El Nuevo Diario, 2012, pág. 1). Fundamentos, que resultan de vital importancia para el proceso comunicativo liderado en Ramiriquí en lo referente a la formalización de tierras, que a continuación se analiza.

\subsubsection{Etapas de la estrategia socio - comunicativa utilizada para la formalización de tierras en Ramiriquí - Boyacá}

El objetivo primordial de la estrategia ha sido "estimular el desarrollo rural y mejorar la calidad de vida de los campesinos, convirtiendo en patrimonio la tierra que ocupan y trabajan desarrollando un mercado de tierras rurales con seguridad jurídica que funcione en forma abierta, ágil y transparente” (Ministerio de Agricultura , 2013, pág. 5). Razón por la cual, la estrategia socio - comunicativa tuvo diferentes frentes, que se consolidaron en dos etapas. La primera se orientó al barrido predial para determinar los predios que iban hacer parte del proceso y la segunda etapa fue el alistamiento previo y reunión con líderes comunales para definir los lugares donde se iban a realizar las socializaciones, siendo en esta etapa donde se dio la intervención de la universidad Santo Tomás, a través del contrato de prestación de 
servicios profesionales cuyo objeto era el de brindar un acompañamiento de líder social ${ }^{3}$ desarrollando procesos de información, atención y gestión de conflictos y mediación entre los mil novecientos once (1911) poseedores y/o propietarios y /o explotadores de baldíos para que se pudiera llevar a cabo la parte técnica y jurídica de saneamiento y formalización masiva de la propiedad rural en Ramiriquí Boyacá. Proceso que se debió llevar a cabo de acuerdo con lo definido en la guía de procedimiento y formalización masiva de la propiedad rural mediante barrido predial del Ministerio de Agricultura y desarrollo rural. Así, las obligaciones por parte de la universidad fueron:

1; Divulgación y socialización: Alistamiento previo y reunión con líderes comunales para definir lugares de realización de las socializaciones del trabajo correspondiente a la etapa 2; se utilizaron las siguientes fases informativas: emisora radial, perifoneo en todas las veredas, llamadas a cada uno de los solicitantes, avisos.

Figura 3. Aviso publicado de socializaciones

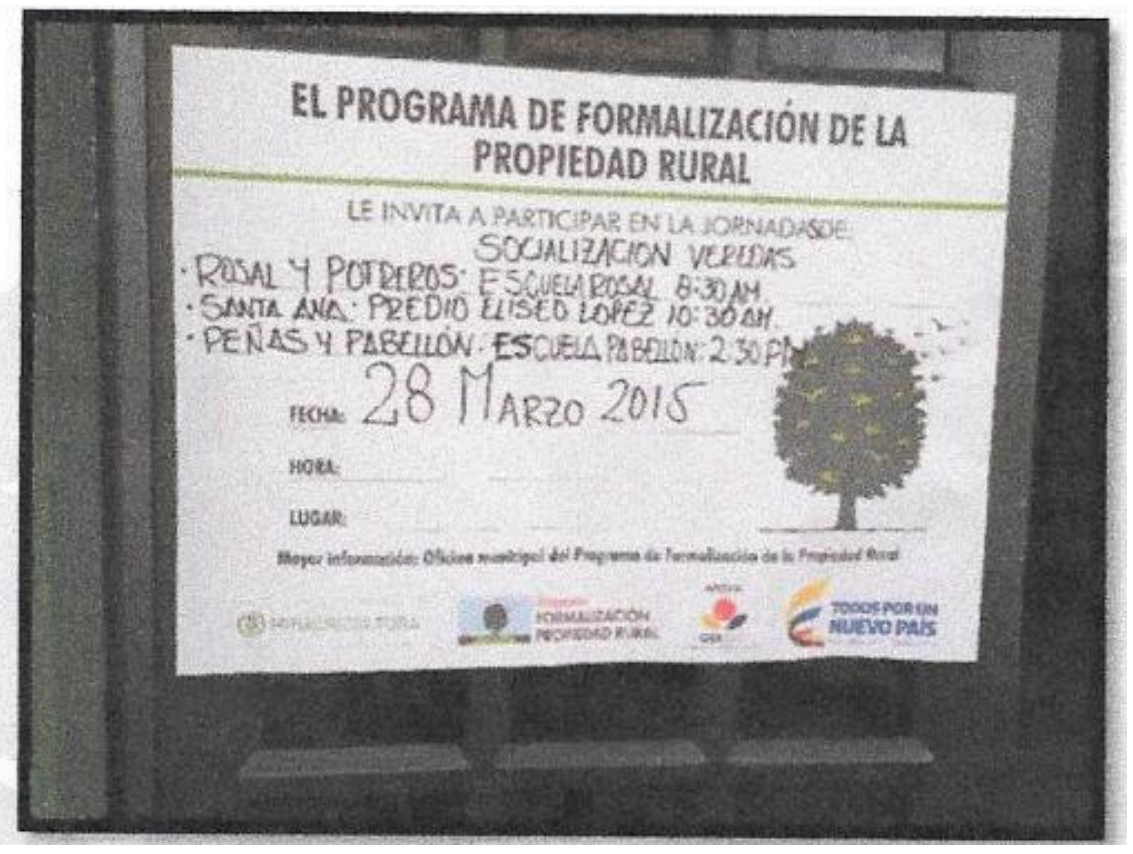

Fuente: (Universidad Santo Tomas, 2015, pág. 4)

${ }^{3}$ El líder social al que hago referencia es la persona que está realizando la presente investigación 
La incidencia social y económica al principio fue positiva, debido a que los campesinos del sector veían en el proyecto de legalización de sus predios por medio de la obtención de un título del inmueble rural como una herramienta para acceder a la formalización e incluso como medio de financiación de sus actividades agrícolas permitiendo el desarrollo económico, social y cultural del municipio, el departamento y con ellos los sectores rurales del país.

Cada proceso tiene diferentes enfoques y tratamiento, social, económico y jurídico al tener una incidencia específica en el tema de adjudicación de tierras; estos enfoques son abordados desde cada una de las etapas del proyecto y los pasos para la adjudicación de los predios. Los primeros pasos se dan de forma efectiva porque no se rigen por un procedimiento estricto, pero al encontrarse con los requerimientos jurídicos se enfrentan con un problema aún mayor al cual se ve abocada la justicia a nivel nacional y lo es el represamiento de procesos y la poca agilidad en la resolución de los mismos.

Así, en lo que a la estrategia socio - comunicativa se refiere, las socializaciones se llevaron a cabo en 4 momentos, las cuales permitieron cubrir las 404 solicitudes realizadas en este momento, realizadas en el teatro municipal, a donde se invitaron las veredas Faravita, Resguardo Alto y Resguardo Bajo; en el Ocal Predio se invitó la población de Santana, en la escuela del Rosal fueron atendidos los solicitantes del Rosal y de Potreros y en la escuela el pabellón se socializó a los beneficiarios de Peñas y Pabellón, trabajo realizado en marzo de 2015.

Tabla 3. Socializaciones

\begin{tabular}{|c|c|c|c|}
\hline \multicolumn{4}{|c|}{ SOCIALIZACIÓN } \\
\hline LUGAR & FECHA & HORA & $\begin{array}{c}\text { CANTIDAD } \\
\text { SOLICITANTES }\end{array}$ \\
\hline TEATRO MUNICIPAL & 26 de marzo & $10: 00 \mathrm{am}$ & 152 \\
\hline EL OCAL ELISEO LÓPEZ & 28 de marzo & $08: 30 \mathrm{am}$ & 58 \\
\hline ESCUELA EL ROSAL & 28 de marzo & $10: 30 \mathrm{am}$ & 69 \\
\hline ESCUELA PABELLÓN & 28 de marzo & 02:30 pm. & 125 \\
\hline
\end{tabular}

Fuente: (Universidad Santo Tomas, 2015, pág. 5) 
Posteriormente a la socialización, se entregaron 394 notificaciones a las personas.

2; Publicación de visitas de campo: El cronograma de visitas preparado por el área de técnica fue publicado junto con el plano de la distribución de las mismas por comisiones en el despacho de la Alcaldía Municipal, la oficina del GTF del Ministerio de Agricultura y Desarrollo Rural, la Institución Educativa Rural de Pabellón, la Institución Educativa Rural de Faravita en las instalaciones en donde funciona la Oficina de la Universidad Santo Tomás, en el listado se especifica código de solicitud, fecha de visita, nombre del solicitante, documento de identidad, cédula catastral y comisión de campo.

3; Casos de mediación: Dentro del proceso de ejecución de la etapa dos del Proyecto de Formalización se realizaron dos mediaciones con el fin de posibilitar la realización de las visitas prediales, de acuerdo con la programación establecida. A continuación, en la tabla 3 se muestran las visitas realizadas con corte a 5 de mayo de 2015.

Tabla 4. Discriminación de visitas realizadas

\begin{tabular}{|l|r|}
\hline \multicolumn{2}{|c|}{ Discriminación visitas realizadas } \\
\hline Visitas realizadas & 417 \\
\hline Casos especiales & $5^{*}$ \\
\hline Inviables & 1 \\
\hline Casos de mediación & 2 \\
\hline *Incluyen predios en riesgo y con visita pendiente \\
\hline
\end{tabular}

Fuente: (Universidad Santo Tomas, 2015, pág. 4)

Tal como se puede ver en la tabla 4 se realizaron de manera exitosa 417 visitas de campo durante el periodo reportado, encontrándose que en las veredas Rosal, Potreros, Santana, Peñas, Pabellón, Resguardo Alto y Resguardo Bajo existe un bajo índice de conflictos sociales (Véase figura 5). 
Figura 4. Formato de predio visitado

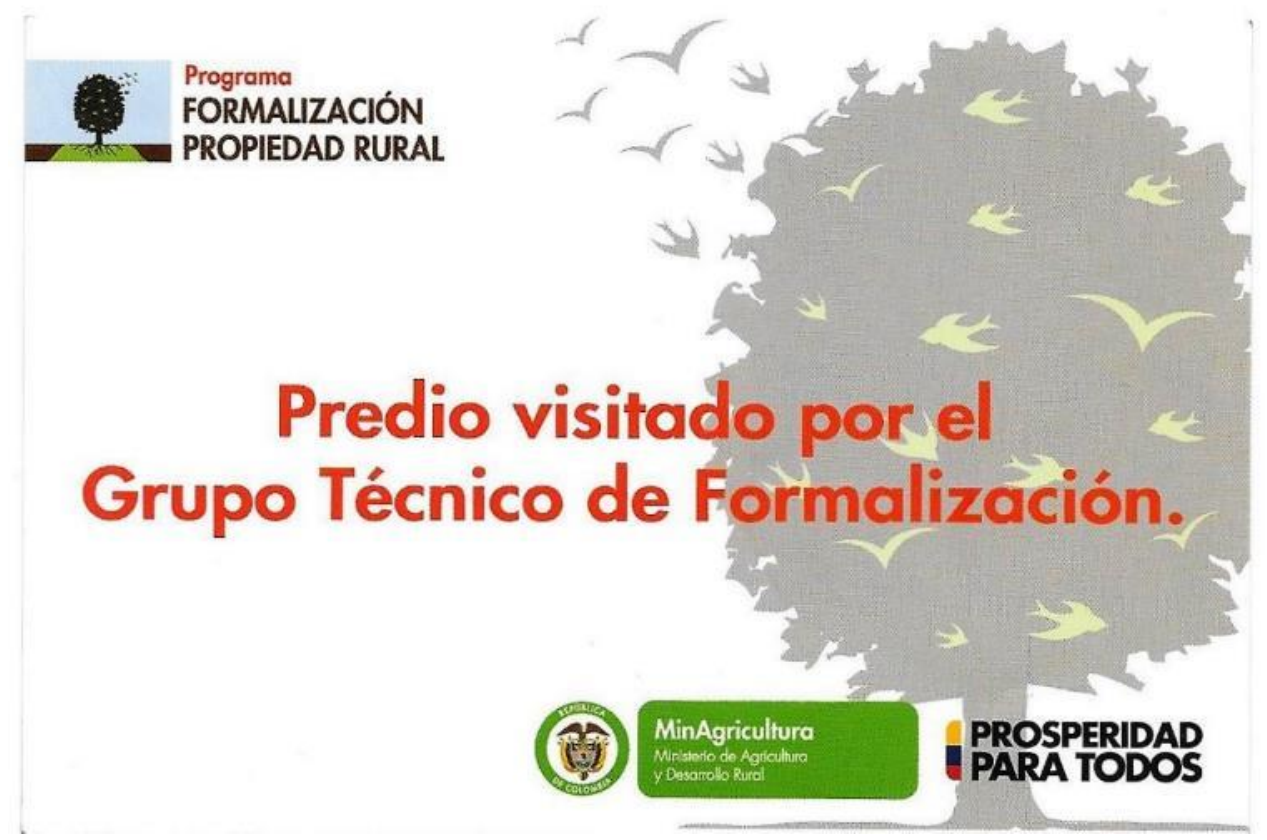

Fuente: (Universidad Santo Tomas, 2015, pág. 6)

Dentro de los casos especiales se encontraron dos con alto riesgo topográfico y natural 3623 y 3624 respectivamente para la seguridad del equipo, razón por la cual no fue posible realizar la visita. El predio 3579 no se pudo visitar debido a que su dueño se encontraba fuera del país.

Se logró en el sector crear un mayor interés por parte de la población, pues en la obtención de los títulos encontraron formas de apalancamiento, término propio de la economía, para lograr una mejora y tecnificación de los procesos para hacer más competitivo el sector del agro. Adicionalmente se despierta el interés por conocer los procesos propios de este proyecto, medir el impacto social y reconocimiento de nuevas formas de socialización y comercialización; aunque a su vez generó descontento al final de los procesos por demoras innecesarias que en muchos casos llevó a que se incurriera en gastos mayores no previsibles desde el principio. 
Finalmente, debe advertirse que el proceso informativo estuvo presente desde la primera etapa. Este sí logró el objetivo planteado que fue informar sobre el programa de formalización, realizado a través de todas sus etapas: socializaciones, visitas, talleres ofrecidos en las escuelas veredales para dar a conocer el programa que se iba a realizar para la formalización de predios.

\section{Resultados guía de observación}

La guía de observación tuvo como fin analizar algunos aspectos importantes de la zona rural de Ramiriquí con el fin de conocer el ambiente socio - económico, el ámbito político, y la experiencia socio - comunicativa con relación a la formalización de tierras. Para tal fin, se llevaron a cabo varias visitas al municipio entre los meses de mayo a julio de 2016.

La guía de observación se desarrolló a partir del contacto con la población de manera informal, atenta y en especial orientada a obtener la información deseada, tal como se muestra en la tabla 5. En la experiencia que se tuvo con la comunidad, se encontró que los campesinos se encuentran interesados en otros asuntos como las precarias condiciones en las que se encuentran algunos y la falta de oportunidades para tecnificar el agro; adicionalmente, querían saber sobre el acceso a financiación para aumentar sus cosechas, cultivos y cómo podían promover sus productos por fuera del municipio, en términos generales el interés de algunos era estrictamente económico. Y en ese orden de ideas la información que ofrecieron fue más bien escasa. 
Tabla 5. Guía de observación

GUÍA DE OBSERVACIÓN

\begin{tabular}{|c|c|c|}
\hline \multicolumn{3}{|c|}{ GUÍA DE OBSERVACIÓN } \\
\hline 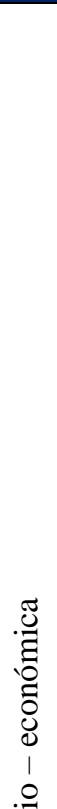 & $\begin{array}{c}\text { ¿Cuáles son las } \\
\text { costumbres sociales de los } \\
\text { campesinos? }\end{array}$ & $\begin{array}{l}\text { Las costumbres de los campesinos pobladores de este } \\
\text { sector están determinadas por los tipos de cultivos a lo } \\
\text { que se dedican, frutas y hortalizas, especialmente frijol, } \\
\text { maíz y tomate y los ciclos de cultivo de cada una de ellas. } \\
\text { También están orientadas a las tradiciones culturales del } \\
\text { municipio siendo una de sus fiestas más representativas } \\
\text { el festival del maíz, el sorbo y la arepa que ofrece una } \\
\text { gran muestra gastronómica, al punto que la festividad ya } \\
\text { se ha hecho a nivel internacional. Adicionalmente } \\
\text { continúan las tradiciones de antaño como el concurso de } \\
\text { bandas musicales, ferias artesanales las cuales siempre se } \\
\text { hacen en el parque principal. } \\
\text { Tanto el concurso de bandas, como las ferias artesanales, } \\
\text { se hacen en ocasiones en compañía de municipios } \\
\text { aledaños como Ciénaga, Sogamoso y Ramiriquí. Estas } \\
\text { actividades culturales promueven, no solamente, el } \\
\text { arraigo de sus costumbres, sino que además contribuyen } \\
\text { con el turismo del municipio y por consiguiente el } \\
\text { crecimiento económico. }\end{array}$ \\
\hline 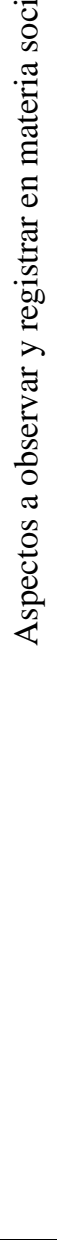 & $\begin{array}{c}\text { ¿Cuáles son los problemas } \\
\text { sociales que más afectan a } \\
\text { los campesinos? }\end{array}$ & $\begin{array}{l}\text { Los problemas sociales que más se presentan están } \\
\text { asociados en muchos aspectos a las condiciones } \\
\text { climáticas que afectan las producciones, una baja } \\
\text { inversión del sector privado en el municipio y la } \\
\text { dependencia de los auxilios económicos provenientes del } \\
\text { Estado. } \\
\text { Pero, también se pudo percibir de los pobladores un } \\
\text { conformismo que los somete a adaptarse a lo que tienen, } \\
\text { sin buscar soluciones, bajo el sofisma de que ellos no } \\
\text { tienen posibilidades, desconociendo los diferentes } \\
\text { programas que tiene el gobierno, de los cuales no tienen } \\
\text { conocimiento. En cuyo caso la Alcaldía municipal señalo } \\
\text { los programas que en infraestructura agrícola poseen en } \\
\text { este momento y que a } 2019 \text { buscan lograr unas metas } \\
\text { propuestas, en cuanto a formular los planes y proyectos } \\
\text { de carácter específico en el marco de la adaptación y/o } \\
\text { mitigación del cambio climático, que permita atender } \\
\text { problemáticas puntuales, específicamente en lo } \\
\text { relacionado con acueducto, alcantarillado, aseo, salud, } \\
\text { educación, transporte, comunicación y seguridad } \\
\text { alimentaria, frente a eventos de origen climático, de } \\
\text { manera articulada con el PICC del departamento de } \\
\text { Boyacá. } \\
\text { Adicionalmente, en cuanto a los cultivos que tienen en su } \\
\text { mayoría lo hacen de forma artesanal, son muy pocas las } \\
\text { fincas tecnificadas. También se han visto afectados por } \\
\text { los paros camioneros que no permiten la salida de los } \\
\text { productos a su destino. Y por obvias razones la } \\
\text { formalización de predios objeto de la investigación, que }\end{array}$ \\
\hline
\end{tabular}




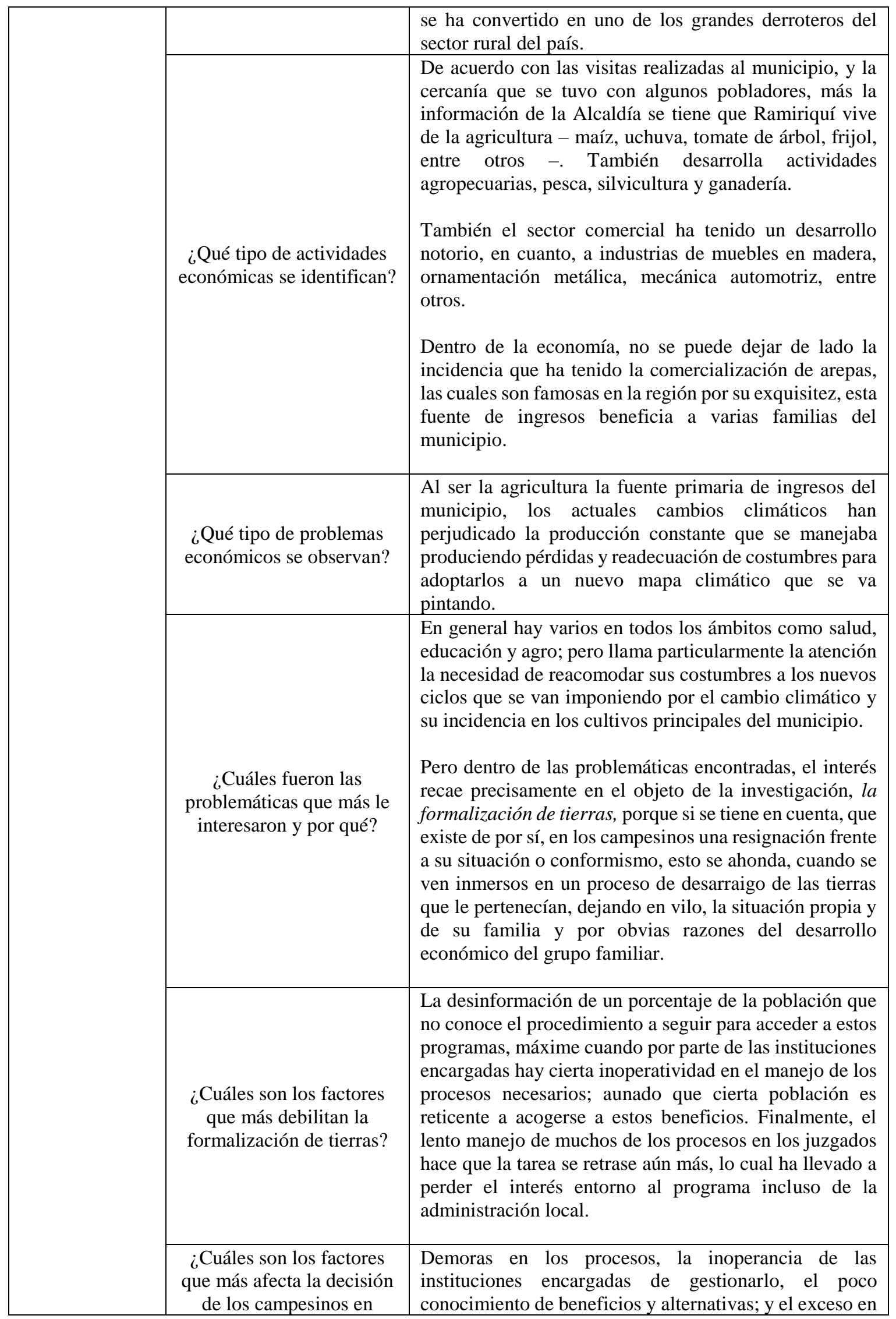




\begin{tabular}{|c|c|c|}
\hline & $\begin{array}{l}\text { Ramiriquí - Boyacá, para } \\
\text { acceder a la formalización } \\
\text { de tierras? }\end{array}$ & $\begin{array}{l}\text { algunos casos de requerimientos para poder acceder al } \\
\text { beneficio. }\end{array}$ \\
\hline \multirow{3}{*}{ 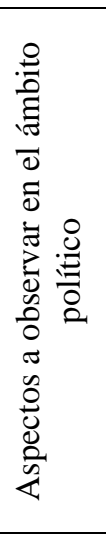 } & $\begin{array}{l}\text { ¿Cómo se ha dado el } \\
\text { proceso de formalización } \\
\text { de tierras? }\end{array}$ & $\begin{array}{l}\text { En general ha tenido un buen recibo por parte de los } \\
\text { habitantes, pues se ha procurado al menos en la } \\
\text { divulgación del programa llegar a todos y explicar en qué } \\
\text { consiste, pero cuando ya se pasa a la ejecución de los } \\
\text { mismos se pierde el interés o al ver los procedimientos } \\
\text { se retractan de la acción. }\end{array}$ \\
\hline & $\begin{array}{l}\text { ¿Las autoridades } \\
\text { municipales promueven la } \\
\text { formalización de tierras? }\end{array}$ & $\begin{array}{l}\text { En el origen del plan fue altamente apoyado por parte de } \\
\text { la administración municipal; sin embargo, con el paso del } \\
\text { tiempo los intereses se han ido desplazando a nuevos } \\
\text { proyectos de la administración municipal. }\end{array}$ \\
\hline & $\begin{array}{l}\text { ¿Cómo es el trámite para } \\
\text { formalizar los predios? }\end{array}$ & $\begin{array}{l}\text { El proceso según lo expresa el ministerio de agricultura } \\
\text { se hace por medio de } 12 \text { pasos, en tres etapas de la } \\
\text { siguiente manera (Véase anexo C). }\end{array}$ \\
\hline \multirow{2}{*}{ 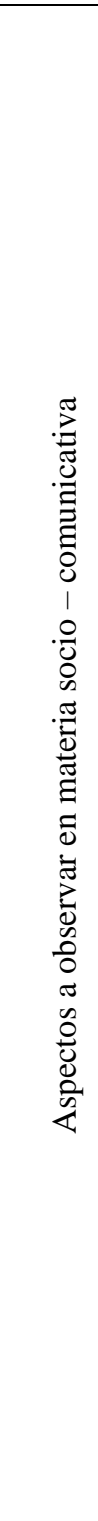 } & $\begin{array}{l}\text { ¿Qué canales de } \\
\text { comunicación ha utilizado } \\
\text { el municipio para dar a } \\
\text { conocer la propuesta la } \\
\text { formalización de tierras? }\end{array}$ & $\begin{array}{l}\text { - Periódico de la región: Son varios los periódicos, pero } \\
\text { el más circulado es El Diario (Véase anexo D) y Extra, } \\
\text { en los cuales se hizo difusión acerca del plan en la región, } \\
\text { que aún están vigentes y tienen versión digital; pero el } \\
\text { anuncio acerca del proyecto ya no se sigue difundiendo. } \\
\text { - Emisora del municipio. La emisora se llama A3 } \\
\text { Andina Estéreo, fue la fuente en la cual se le hizo mayor } \\
\text { publicidad al plan, por ser el medio al que tiene mayor } \\
\text { acceso la población de todo lo sectores, aún existe, pero } \\
\text { la propaganda del tema ya no se sigue promocionando. } \\
\text { - Carteles en la alcaldía y algunos lugares públicos del } \\
\text { municipio. La gente los recuerda, pero ya no los han } \\
\text { vuelto a sacar a partir del cambio de administración. } \\
\text { - Visita de los promotores del programa, las visitas son } \\
\text { menos esporádicas como antes, y no son los promotores } \\
\text { sino los que están ayudando con los papeleos de los que } \\
\text { están en proceso, orientando a las personas hacia donde } \\
\text { se deben dirigir - Juzgado, Alcaldía, abogados - }\end{array}$ \\
\hline & $\begin{array}{l}\text { ¿Cómo ha sido la } \\
\text { divulgación que ha hecho } \\
\text { el municipio sobre la } \\
\text { formalización de tierras? }\end{array}$ & $\begin{array}{l}\text { Para promover la estrategia comunicativa de la } \\
\text { formalización de tierras, conforme a lo conversado con } \\
\text { funcionarios de la Alcaldía y los mismos campesinos, la } \\
\text { mejor ha sido el "voz a voz" que se ha convertido en una } \\
\text { forma de dar a conocer el programa, ofreciéndoles a las } \\
\text { personas, en cierta forma, la confianza para comenzar su } \\
\text { proceso. } \\
\text { También existen una serie de herramientas } \\
\text { institucionales, que promueven el programa como: } \\
\text { carteles informativos dispuestos dentro de la Alcaldía, el } \\
\text { Ministerio de Agricultura, Personería Policía Nacional, } \\
\text { también se ha utilizado el sistema de visitas por parte de } \\
\text { funcionarios de la Alcaldía para informar sobre el } \\
\text { proceso de formalización, tal como se pude ver en los }\end{array}$ \\
\hline
\end{tabular}




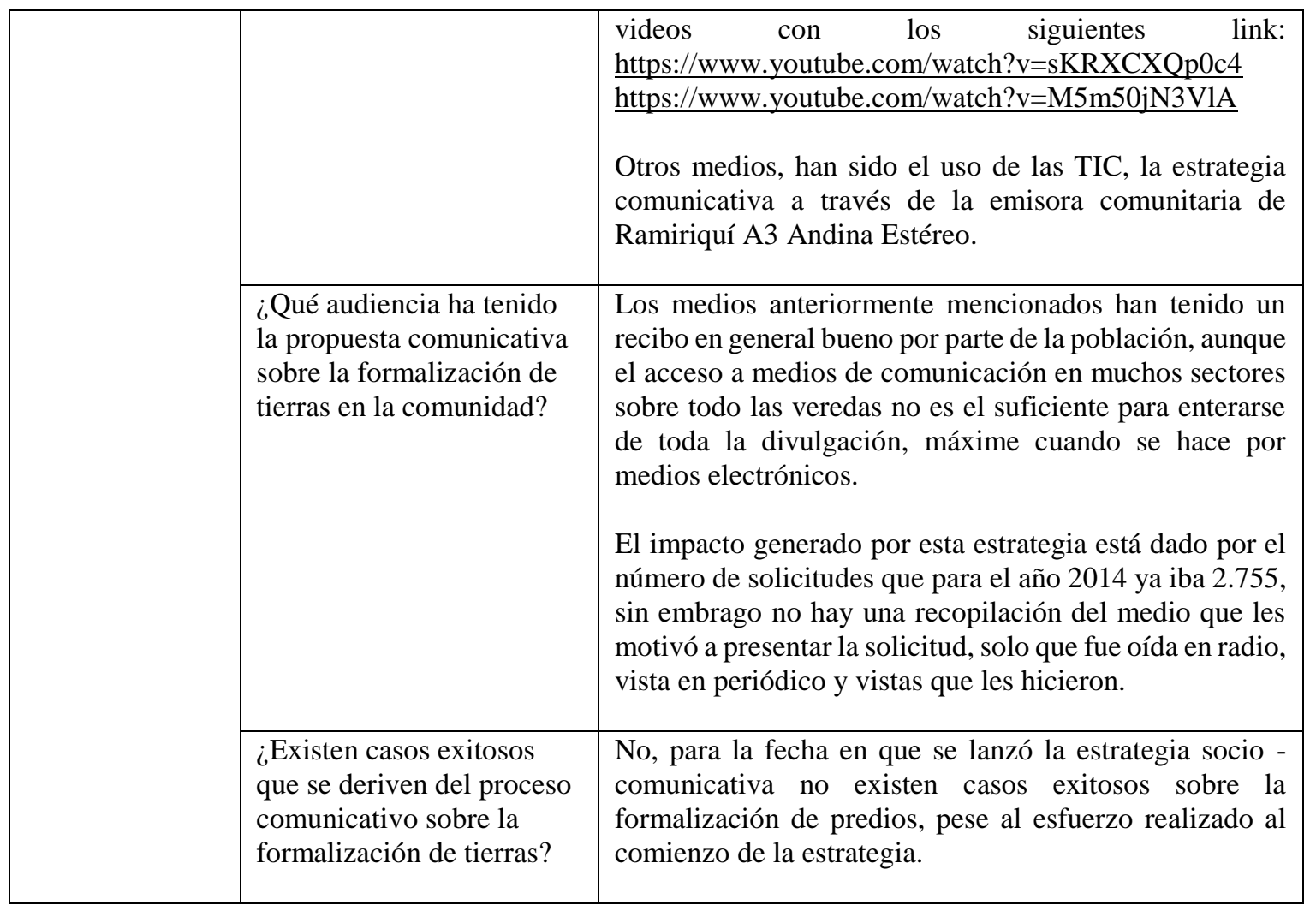

Fuente: autor

\section{Resultados de la entrevista}

De acuerdo con las visitas realizadas al municipio, se lograron hacer ocho (8) entrevistas a funcionarios de diferentes entidades: Alcaldía municipal, Ministerio de Agricultura, Oficina asesora de Planeación e infraestructura, Personería, Dirección Administrativa de la Unidad de Servicios públicos y Policía Nacional (Véase anexo B). Así, en la Alcaldía se entrevistaron a dos de los funcionarios que hicieron el recorrido en las veredas, contándole a los pobladores sobre el programa de formalización de tierras y a un funcionario que está encargado de los diferentes medios de divulgación - TIC, emisora, charlas, carteleras, entre otras -se logró entrevistar a un funcionario del Ministerio de Agricultura, que ha tenido relación con este proceso y de las demás entidades a cuatro funcionarios que de alguna forma han tenido que ver o se acuerdan de lo sucedido. 
Con referencia a la pregunta uno, sobre el conocimiento de la formalización de tierras, se logró establecer, por parte, de quienes tuvieron la vivencia de ir a las zonas rurales, que el programa en su comienzo, mediados de 2014 fue un éxito además porque el municipio fue escogido como prueba piloto. Esto significa, que quienes tuvieron la oportunidad para la época de acogerse al programa han logrado resultados importantes como formalizar sus predios, aunque aún algunos no lo lograron a causa de inadecuados procesos administrativos. Por ejemplo, información contradictoria (se les preguntó que sí tenían un registro reciente sobre el proceso de formalización, a lo que contestaron que esa información la manejaba el Ministerio de Agricultura y que además en lo corrido de 2016 no se ha hablado del asunto, que hasta ahora van a volver a abrir la oficina), falta de personal para atender el número de solicitudes, o una verdadera participación de la población en el momento de elaborar el programa.

Los demás funcionarios dijeron conocer del proceso, pero como todo, fue muy renombrado y liderado en el 2014, en el 2015 apenas se lograron ofrecer información pertinente sobre los procesos en curso y en el caso de la Policía se han hecho algunas visitas, pero por tema de invasiones. En la pregunta dos, relacionada con el apoyo ejercido por las entidades en el proceso de formalización de tierras, se estableció que la presencia directa fue de la Alcaldía, Ministerio de Agricultura, Personería y Policía Nacional. Desde la Alcaldía se ha apoyado el proyecto el cual sigue aun en ejecución por algunos inconvenientes que se han presentado, se ha contado con el apoyo adicional del Instituto Colombiano de Desarrollo Rural INCODER - en algunos casos, el Agustín Codazzi y la gobernación de Boyacá. La Personería en su momento atendió quejas y reclamos, orientando a los campesinos en la forma como debían comenzar el proceso de formalización y la Policía Nacional contribuyó con capacitaciones en asocio con las demás entidades. También es importante destacar en el 2014 cuando se dio el boom de la formalización de tierras en el municipio, la colaboración de la emisora A3 Andina Estéreo, que en diferentes horarios brindo la información pertinente, para que los campesinos se hicieran parte en el proceso.

En la pregunta tres, que buscaba saber los inconvenientes para la formalización de tierras, se logró establecer que el mayor inconveniente es que los procesos ante los juzgados, son 
muy lentos y en consecuencia no se ha logrado la formalización de la totalidad de los predios; lo cual ha conllevado a la perdida de interés de algunas personas y la mala intención de algunos abogados que se aprovechan de ello, conforme lo señalado por el funcionario de la Personería, teniendo que atender quejas en la forma como algunos abogados llevaban los procesos. También señaló el funcionario encargado de la divulgación del programa de la Alcaldía que las personas no leen o no entienden de qué se trata, porque en muchas ocasiones, le preguntaban sobre lo que aparecía en las carteleras, o sobre lo que informaba la radio, también señaló que mucha gente no creyó en el programa y a pesar de haber ido a las charlas nunca comenzaron el proceso y por último la precarias condiciones de algunos campesinos no les dieron la oportunidad de acceder a este programa, debido a que no contaban con el dinero para comenzar un proceso de esta magnitud.

En la pregunta cuatro, concerniente al apoyo de las autoridades departamentales y nacionales en pro de promover la formalización de tierras, todos contestaron que al comienzo el apoyo fue total y más por ser Ramiriquí el municipio escogido para la prueba piloto. A lo que se le suma las estrategias de sensibilización con la población, sobre todo las gestionadas por el Ministerio de Agricultura; pero esas acciones muchas veces quedan relegadas debido a los problemas que se empezaron a presentar en algunos procesos en los juzgados y el cambio de prioridades de atención en el municipio. También expresó el funcionario de Oficina asesora de Planeación e infraestructura que existió un significativo apoyo del Agustín Codazzi, el INCODER y creo que se han visto vinculadas también entidades como la Superintendencia de Notariado y Registro entre otras, el departamento también fue fundamental, pues fue con quien se hizo la alianza principal. Todos estuvieron de acuerdo, que en el 2014 existió un gran despliegue de ayuda y colaboración por parte de todas las entidades tanto públicas como privadas, en pro de promover la información necesaria para que el programa de formalización de tierras alcanzará su más alto nivel.

En cuanto a saber sobre el aporte de entidades no gubernamentales, como fundaciones, asociaciones o empresas privadas, en relación con la formalización de tierras, se encontró que el principal impulso ha sido de entidades estatales y organismo creados a partir de estos, tales como el Ministerio de Agricultura, el Instituto Geográfico Agustín Codazzi, la 
Superintendencia de Notariado y Registro, el Consejo Superior de la Judicatura, la Unidad de Planeación Rural y Agropecuaria, el INCODER entre otros. Aunque la mayoría de los entrevistados dijeron no saber, expresando que hasta dónde saben todos han sido entes oficiales.

A manera de conclusión se puede afirmar que el mayor inconveniente que tuvo el proceso de formalización de tierras en Ramiriquí fue que el municipio no manejó directamente el proyecto, sino que fue liderado por el Ministerio de Agricultura con contratistas particulares en confinanciación, entre el Ministerio y la gobernación de Boyacá. En este sentido, el programa alcanzó a realizar solamente 50 sucesiones y en relación con el saneamiento de los predios que es darle la titularidad a la persona, no se dio ni uno. Se comenta, que el proyecto está nuevamente por comenzar.

Otro aspecto, que afectó el proceso fue el componente estructural, debido a que, el Ministerio de Agricultura supuso que era fácil llevar a cabo 5000 o 10000 procesos de pertenencia basados en la Ley 1561 de 2012, Ramiriquí cuenta apenas con dos juzgados uno promiscuo y otro civil, ¿cómo pretendían, que tal número de procesos se pudieran evacuar? Quien los saca, situación que le generó la expectativa a todo el mundo de que en un año se iban a sacar los procesos de titularidad.

Significa, que el proceso informativo tuvo la acogida deseada, en cuanto a dar a conocer una propuesta de solución a través de una estrategia que mostró la posibilidad de formalizar los predios, la cual establecía un proceso rápido y gratuito que daría como resultado la titularidad del predio. Lo que se buscó con esta propuesta era brindarles a los ciudadanos de Ramiriquí la posibilidad de tener sus tierras con los documentos al día y sin costo; es decir, que las personas no tenían que entrar en gastos de abogados, lo que debían cancelar era lo concerniente al trámite como fotocopias, edictos, autenticaciones, entre otras. La parte de llegarle a la gente fue un éxito total, debido a que se previó que iban a llegar 5000 predios y llegaron como 8000 , lo que significa que el $75 \%$ de los predios están viciados y que requieren de la debida formalización. 
Lo que se hizo mal, fue el desarrollo de las etapas que surtía cada proceso, momento en el cual las personas comenzaron a desencantarse, porque se dieron cuenta que el proceso era demorado, todo debido a la falla estructural que tuvo éste, pues el municipio no cuenta con los juzgados necesarios, ni con el personal necesario, así como que el municipio para el manejo directo del proceso no contrató abogados adicionales; es decir, que la estrategia estuvo en manos de las dos personas que trabajan en el juzgado que conocen del tema abogados -, el juez y el secretario.

Situación que dejó como consecuencia, que las personas se salieran del programa para contratar un abogado; aspecto que deja como experiencia que el proyecto se debe estructurar conforme a las necesidades propias de cada municipio, con personas que conozcan las particularidades de éste, necesidades y un ejercicio que integre la participación de la población en el proceso de planificación del proyecto, del diagnóstico, para finamente hacer un plan, administrativo y financiero que tenga en cuenta los requerimientos del recurso humano, económico, imprevistos, entre otros.

\section{Estrategia socio - comunicativa}

En el presente apartado se busca mostrar cómo se estructura la estrategia socio comunicativa liderado por el Ministerio de Agricultura, la cual se muestra conforme se fue desarrollando. Así, la estrategia se inicia con un proceso metodológico, a través del cual se buscó mostrar los componentes de la estrategia por medio de etapas. Después, se realizó el diseño de la cartilla que se repartiría a las personas interesadas en la zona rural del municipio, unido a las cuñas publicitarias que promovían la formalización; por último, se hizo el lanzamiento de la misma en la plaza pública del Ramiriquí (Véase figura 5). 
Figura 5. Proceso de la herramienta comunicativa

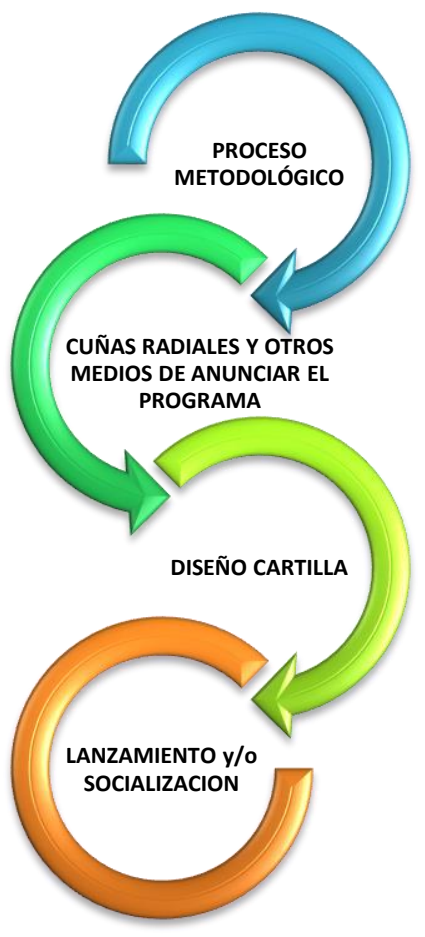

Fuente: autor

- Proceso metodológico: Para establecer el alcance de la propuesta comunicativa liderada por el Ministerio de Agricultura (2013) se utilizó la guía metodológica para la formalización masiva de la propiedad rural por barrido predial. El proceso de formalización de tierras en Ramiriquí Boyacá 2012 - 2015, se cumplió, a partir de la Resolución número 000347 de 2014 expedida por el Ministerio de Agricultura y Desarrollo Rural, cuyo esquema se estableció de la siguiente manera (Ministerio de Agricultura y Desarrollo Rural, 2016, pág. 19):

- Aprestamiento Nacional y Local y focalización, "hizo referencia a las actividades, acciones, medidas y estrategias desde el nivel nacional y local requeridas previamente, que permitieron una intervención más eficiente e integral del territorio" (Ministerio de Agricultura y Desarrollo Rural, 2016, pág. 19), como: el formato de notificación (Véase anexo E), cronograma de visitas publicado en la Alcaldía municipal, oficina de la USTA y Escuela Pabellón (Véase anexo F). 
- El procedimiento de formalización estuvo conformado por dos (2) Etapas y cinco (5) Pasos, en donde se visualizó y conceptuó el proceso de regularización de la propiedad rural.

Figura 6. Programa de la formalización de la propiedad rural

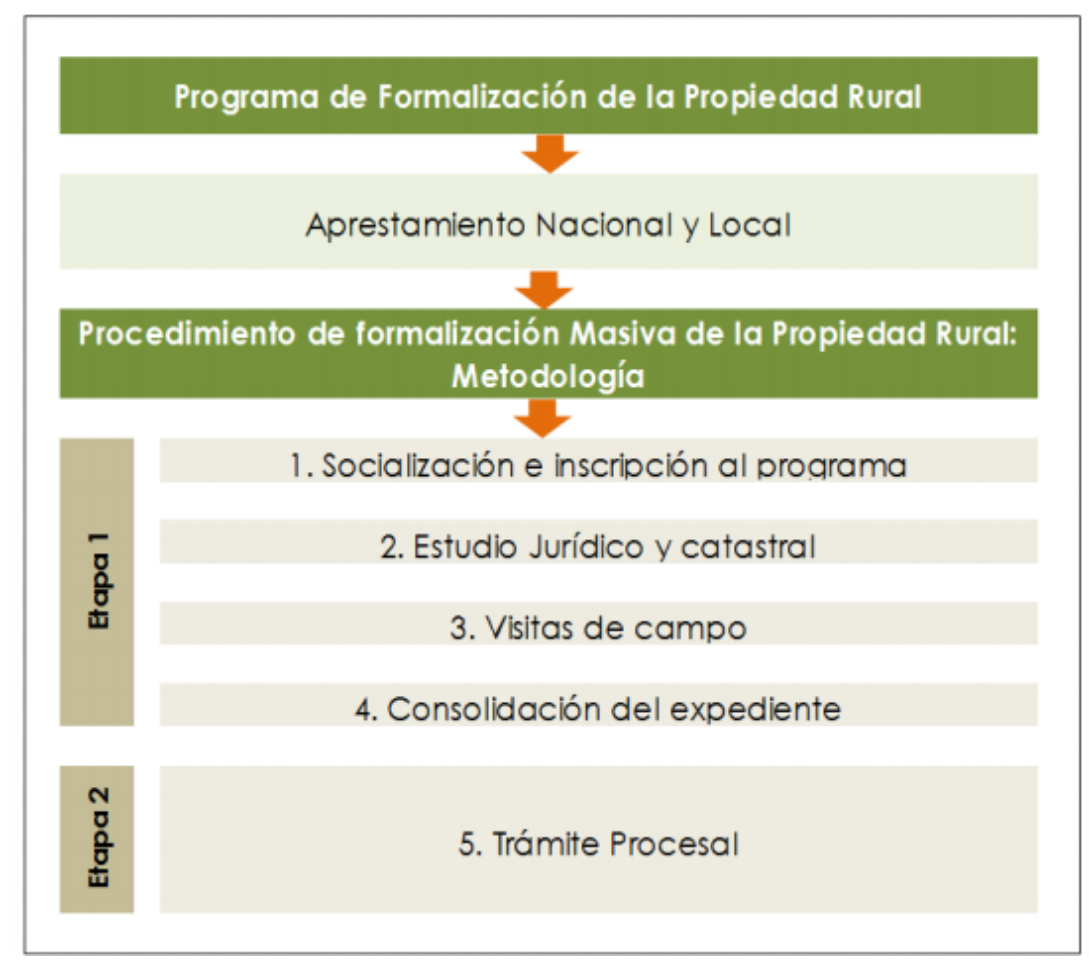

Fuente: Ministerio de Agricultura y Desarrollo Rural (2016)

- Qué comunicar: El programa de formalización llegó al municipio con un equipo de expertos que orientó y acompañó al Ministerio de Agricultura (2016) y demás entidades intervinientes, "en dar a conocer sobre la formalización y las ventajas que esto traería para el municipio" (pág. 19).

- Proceso de elaboración de las cuñas radiales: El proceso comunicativo, conforme a la metodología para la formalización masiva de la propiedad rural por barrido predial propuesta por el Ministerio de Agricultura (2016) debió contar con unas particularidades que se lograron establecer con las Juntas de Acción Comunal - JAC -, la Alcaldía y Personería Municipal, que corresponde a este punto al medio sonoro. 
- El lenguaje y mensaje utilizado para la elaboración de las cuñas radiales debió captar la atención de la comunidad, aspecto que fue muy bien logrado. De esta forma el lenguaje fue comprensible para el público al que estaba dirigido; pues era claro, gracias a que se utilizaron términos como: campesino, tierra, titulación, reuniones, campo, familia, hijos. En el caso de las cuñas estás se hicieron cantadas con música típica de Boyacá - torbellino, bambuco, guabina -; adicionalmente indica el lugar de las reuniones con horarios y fechas, tal como se muestra a continuación.

Figura 7. Cuñas publicitarias de la pieza informativa sobre formalización de tierras en Ramiriquí - Boyacá

Mi tierra, mi tierra, mi campo, mi tierra es lo único que tengo y que puedo dejarles a mis hijos, tierra formal campo ideal, programa de formalización de la propiedad rural, un camino a la titulación de la tierra.

.... El Ministerio de Agricultura y Desarrollo Rural y la Alcaldía de Ramiriquí, anuncia a sus usuarios el programa de la formalización de la propiedad rural; que solo se estarán recibiendo documentos faltantes de sus expedientes hasta el día jueves 18 de junio, los esperamos en la oficina ubicada en el segundo piso de la antigua estación de policía, horario de atención 9 de la mañana a 1 de la tarde de martes a jueves.... Ahora si me siento bien en recuperar mi tierrita, mi familia está tranquila mi vereda esta bonita. Ministerio de Agricultura y Desarrollo Rural, un mensaje del gobierno de la República de Colombia prosperidad para todos; mi tierra, mi tierra, mi campo, mi campo.

...Mi tierra, mi campo, mi campo, mi tierra; es lo único que tengo y que puedo dejarles a mis hijos, mi tierra formal campo ideal; el programa de la formalización y de la propiedad rural, un camino a la titulación de la tierra; el Ministerio de Agricultura y Desarrollo Rural y la Alcaldía de Ramiriquí, invita a toda la comunidad interesada en inscribirse en el programa de la formalización y de la propiedad rural, un camino a la titulación de la tierra...

...El Ministerio de Agricultura y Desarrollo Rural y la Alcaldía de Ramiriquí, de la vereda del Hortigal a la jornada de recepción de solicitudes que se realizará el día viernes 5 de junio en la escuela de Hortigal a partir de la 8 de la mañana hasta las 3 de la tarde; no olvide es indispensable presentar la cédula de ciudadanía y certificado de libertad y tradición y demás documentos relacionados con el predio, como recibo de impuesto predial, copia de escritura o documento de compraventa; si es un caso de posesión, la copia de paz y salvo del impuesto predial, recuerde su mejor seguro es ser propietario con todas las de la Ley...Aquí me siento bien en recuperar mi tierrita, mi familia está tranquila, mi vereda esta bonita. Ministerio de Agricultura y Desarrollo Rural, un mensaje del gobierno de la República de Colombia prosperidad para todos; mi tierra, mi campo, mi campo...

Mi tierra, mi campo, mi campo, mi tierra; es lo único que tengo y que puedo dejar mis hijos, mi tierra formal campo ideal; el programa de la formalización y de la propiedad rural, un camino a la titulación de la tierra...

El Ministerio de Agricultura y Desarrollo Rural y la Alcaldía de Ramiriquí, invita a toda la comunidad interesada en inscribirse en el programa de la formalización y de la propiedad rural de la vereda de Guayabal a la reunión de socialización que se realizará el día domingo 7 de junio en el parque central de Fátima a partir de las 2 de la tarde, su mejor seguro es ser propietario con todas las de la ley...Por aquí me siento bien en recuperar mi tierrita, mi familia está tranquila, mi vereda esta bonita. Ministerio de Agricultura y Desarrollo Rural, un mensaje del gobierno de la República de Colombia prosperidad para todos; mi tierra, mi campo, mi campo.

Fuente: emisora A3 Andina Estéreo (2017) 
Como se puede observar en la figura 7 , los mensajes fueron claros, entendibles y con palabras de fácil reconocimiento, para el campesino, con ejemplos y analogías que le permitieron identificar el programa que le estaban ofreciendo. Además, como se mencionó arriba, la cuña publicitaria, se realizó con identificación del sitio dónde se iba a llevar la reunión, día y la hora. El rótulo de la grabación tenía establecido hasta que día debía pautarse; pero no se encontró la fecha de inicio ni año, teniendo en cuenta que el periodo de la experiencia comunicativa comenzó su construcción desde 2012 y se hizo realidad hasta el primer semestre de $2015^{4}$.

Respecto a las cuñas, se tuvo la oportunidad de preguntar de manera informal a algunos campesinos, sí estás eran de fácil entendimiento, sí lo propuesto era de su interés, sí las reuniones programadas se llevaron a cabo en el lugar, hora y fecha señalada. A lo que respondieron -5 campesinos - , lo siguiente:

En cuanto al entendimiento, cuatro respondieron que sí y uno dijo que no, pero que igual él había asistido a la reunión para ver si entendía. En lo relacionado a lo propuesto, sí logró despertar el interés de todos cinco, preguntándoles que cuál era la parte que más habían entendido, señalando el estribillo que dice: ahora sí voy a recuperar mi tierrita, lo que lleva a pensar que el campesino que dijo no haber entendido la razón de ser de la cuña radial, o no entendió la pregunta o contesto de forma distraída.

Por último, todos afirmaron que las reuniones se habían cumplido tal cual como lo anunciaba la cuña, lo que le dio seguridad y tranquilidad frente al tema de recuperar sus tierras.

- Difusión por reuniones y carteleras: La cuña radial anunció, lo que se iba hacer, entonces el siguiente momento fue llevar acabo las reuniones $\mathrm{y}$, además, afianzar la estrategia por medios como carteleras.

\footnotetext{
${ }^{4}$ Al respecto deseo aclarar que la persona que me facilitó las cuñas no fue la misma que estuvo en el momento de la estrategia; que, a la entrega de los archivos, estos no tenían fecha, exactamente año.
} 
A marzo de 2015 se llevaron a cabo 4 socializaciones, donde se cubrió el total de solicitudes, las cuales fueron realizadas en el teatro municipal, asistiendo como invitadas las veredas de Faravita, Resguardo, Alto y Resguardo bajo; en El Ocal Predio se invitó a la población de Santana, en la escuela del Rosal fueron atendidos los solicitantes del Rosal y de Potreros y en la escuela el pabellón e socializó a los beneficiarios de Peñas y Pabellón, a la socialización asistieron 404 personas conforme el informe presentado por la Universidad Santo Tomás a 2015 (Véase figura 10).

Al finalizar cada una de las socializaciones "se les hizo entrega a las personas de la notificación, y a las que no asistieron se les llamó para hacerlo. En físico se entregaron 394 notificaciones” (Universidad Santo Tomás, 2015, pág. 3) (Véase anexo F).

Después de las socializaciones, se realizaron las visitas de campo, cuyo proceso se llevó a partir de la publicación del cronograma de visitas preparado por el área técnica y publicado junto con el plano de la distribución de las mismas por comisiones en el despacho de la Alcaldía Municipal, en la oficina del grupo técnico de formalización - GTF - del Ministerio de Agricultura y Desarrollo Rural, las instituciones educativas Rural de Pabellón y Rural Faravita y en las instalaciones donde funciona la Oficina de la Universidad Santo Tomás, en el listado se especifica código de solicitud, fecha de visita, nombre del solicitante, documento de identidad, cédula catastral y comisión de campo. 
Figura 8. Jornadas de socialización
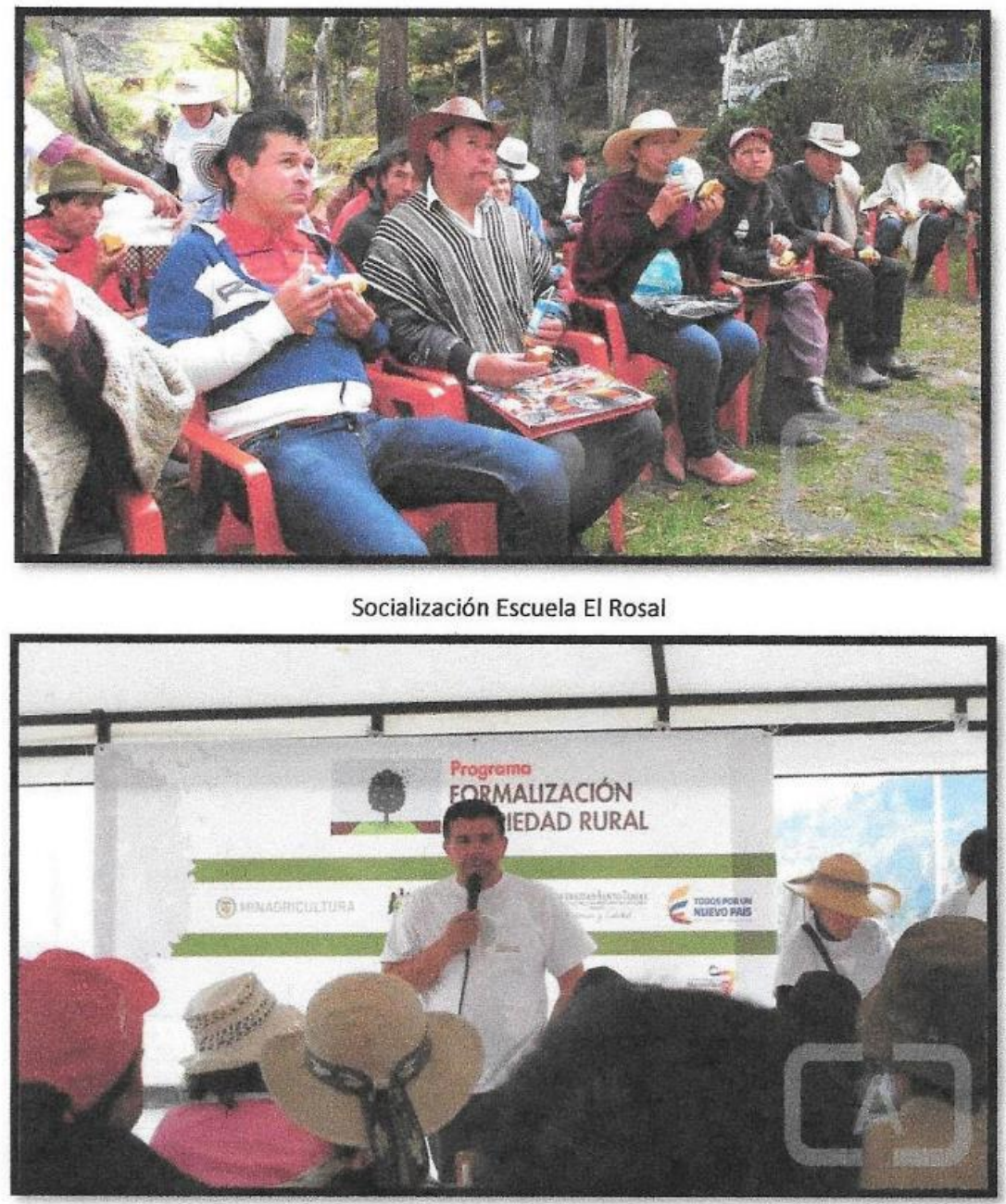

Socialización El Ocal_Eliseo López

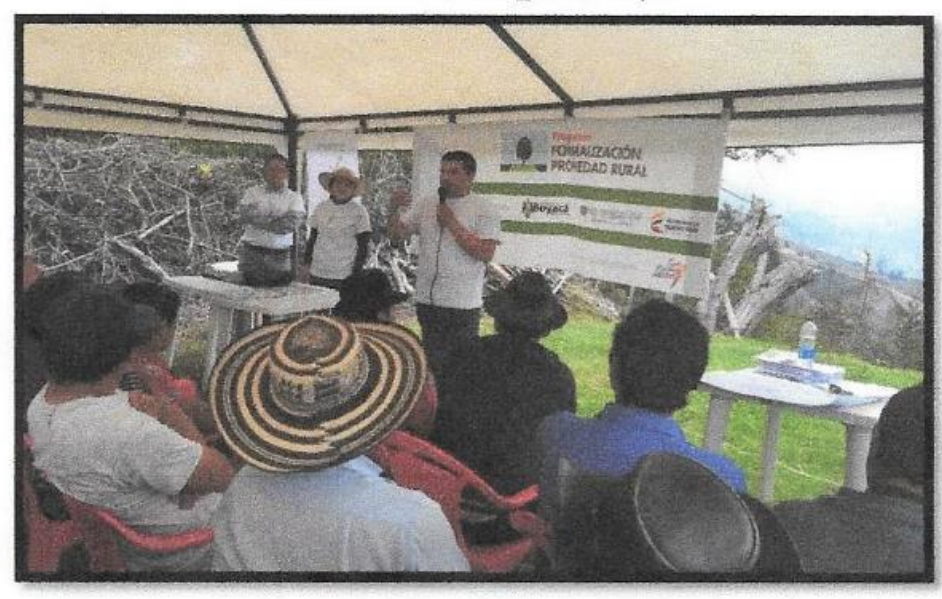

Socialización El Ocal_Eliseo López 

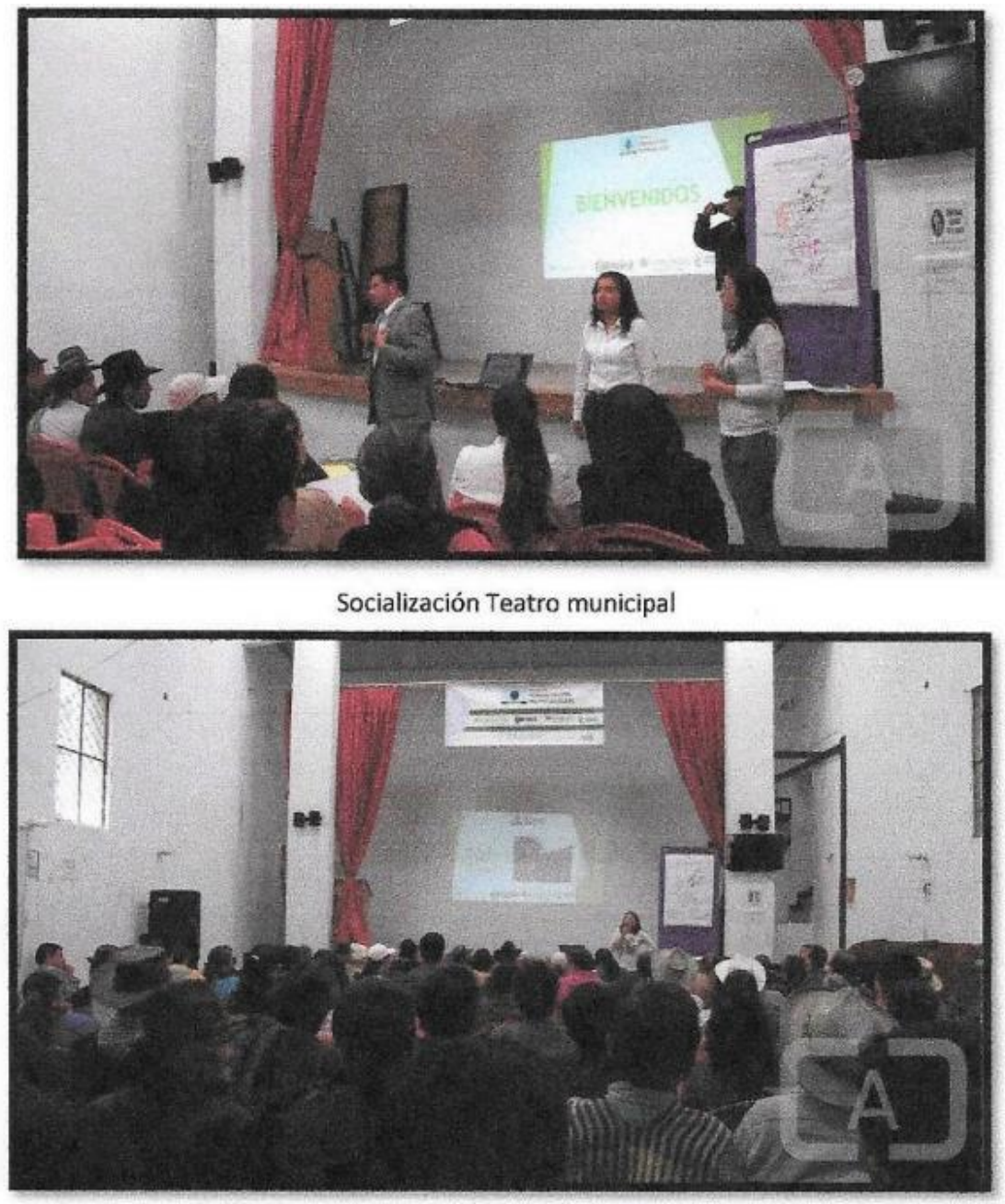

Socialización Teatro municipal

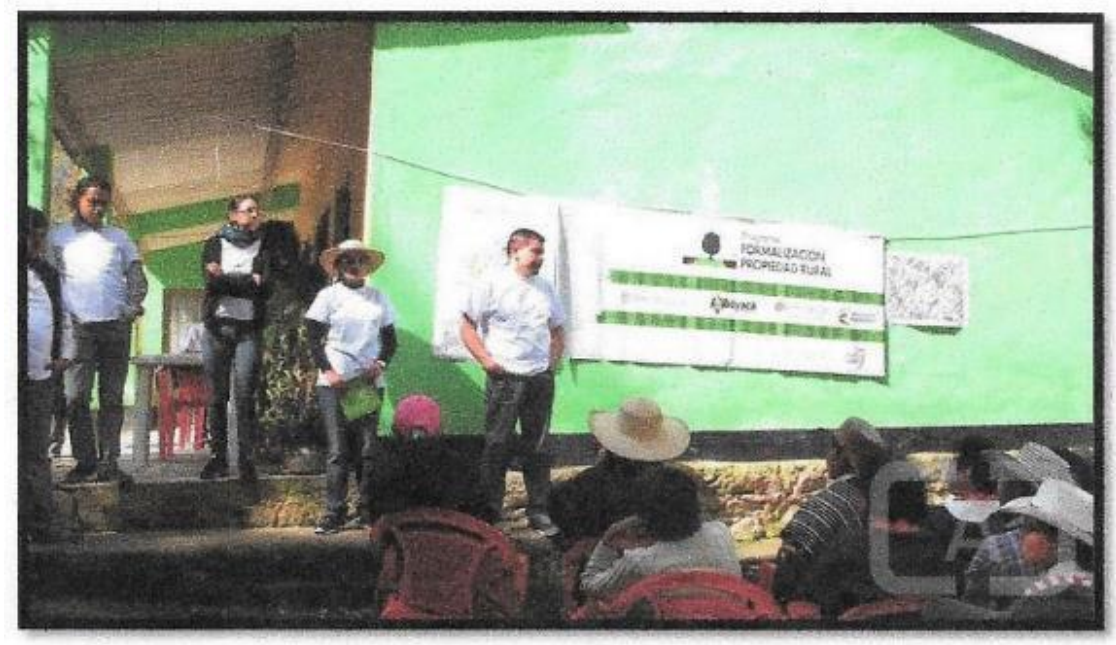

Socialización Escuela El Rosal

Fuente: Alcaldía de Ramiriquí (2015) 
En este orden de ideas, se llevaron a cabo con "corte a 5 de mayo de 2015, 425 visitas encontrándose que en las veredas Rosal, Potreros, Santana, Peñas, Pabellón, Resguardo Alto y Resguardo Bajo existe un bajo índice de conflictos sociales" (Universidad Santo Tomás, 2015, pág. 4).

Al margen de las anteriores actividades y en cumplimiento de las obligaciones encomendadas, con relación a la atención de los usuarios que han requerido orientación acerca del programa y sobre el estado de avance de sus solicitudes, se llevaron a cabo las siguientes actividades (Universidad Santo Tomás, 2015, pág. 4):

- Recepción de capacitación brindada por parte del GTF municipal el día 6 de marzo de 2015;

- Asistencia a reuniones del equipo base programadas por el GTF municipal

- Elaboración de actas de las reuniones del equipo de trabajo, recolección y custodia de planillas de asistencia y evidencias fotográficas cuando sean solicitadas,

- Cotización y solicitud de elaboración de chalecos institucionales para el equipo de trabajo.

- Elaboración de listado de notificaciones pendientes para realizar llamadas a los usuarios,

- Elaboración de notificaciones de nuevas solicitudes,

- Seguimiento a llamadas previas a las visitas de campo,

- Elaboración del listado del equipo de trabajo el cual contiene labor desempeñada números de cédula, celular y correo electrónico,

- Verificación en el SIG de los formatos sociales y logos del programa actualizados y

- Elaboración de comunicaciones interinstitucionales de Ramiriquí

Todos los momentos antes señalados constituyeron el soporte de la estrategia socio comunicativa cuyo insumo final fue la cartilla que se entregó en las diferentes socializaciones y visitas de campo, a través de la cual se muestra el paso a paso, para que las personas comprendieran la forma como se iba a lograr este proceso.

- Cartilla formalización propiedad rural: La cartilla realizada por el Ministerio de Agricultura y Desarrollo Rural, se realizó pensando en el público hacia el cual estuvo 
dirigida, en la que se tuvo en cuenta el lenguaje, los colores, las personas, haciendo de ésta un instrumento didáctico de fácil comprensión.

Figura 9. Diseño de la cartilla sobre formalización de tierras
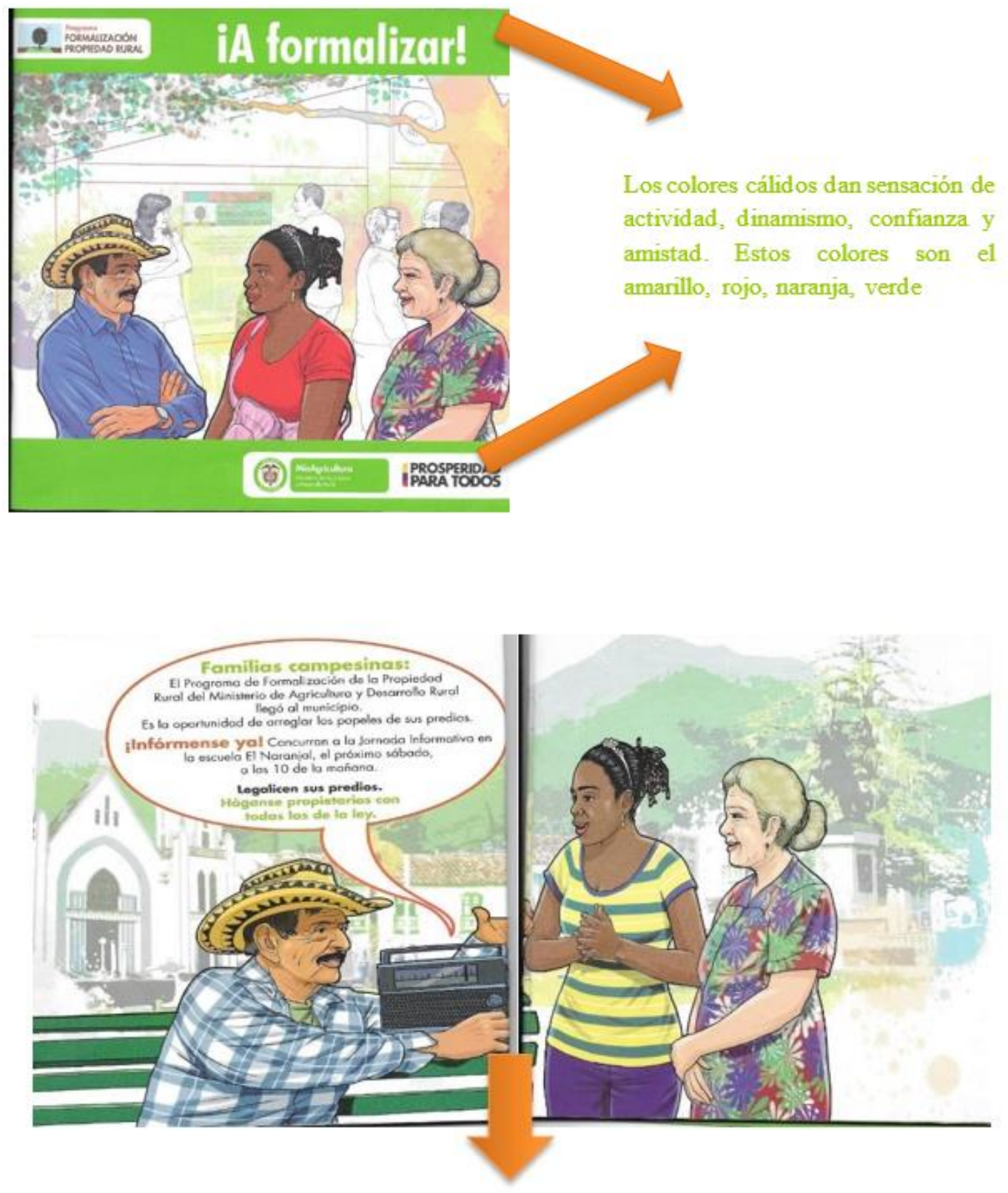

La imagen de marca, se hizo a través de las personas que tienen el estereotipo de quienes van a recibir la orientación sobre la campaña comunicativa, acompañada del contexto, es decir, la naturaleza 


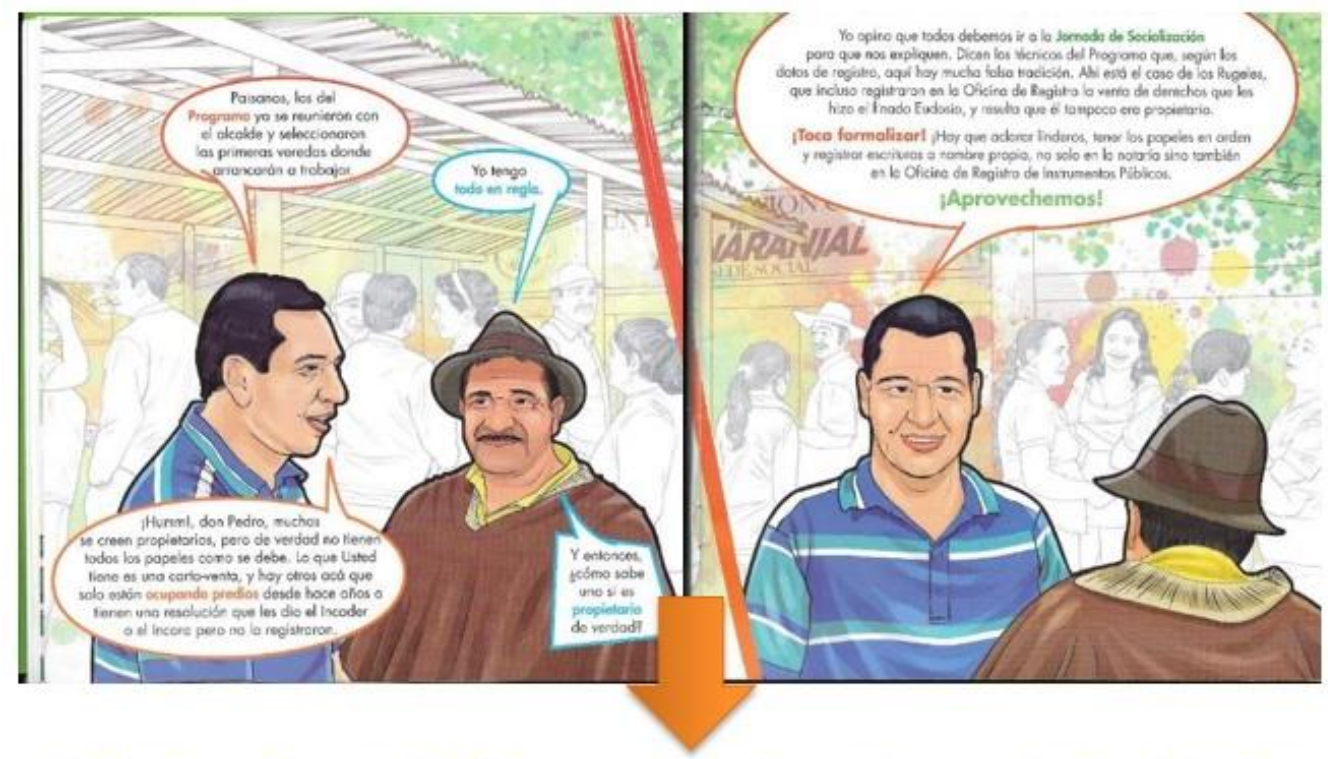

Se buscó en la campaña fijar unos estereotipos, patrones a través de imágenes estandarizadas comunes a la población que va dirigida.

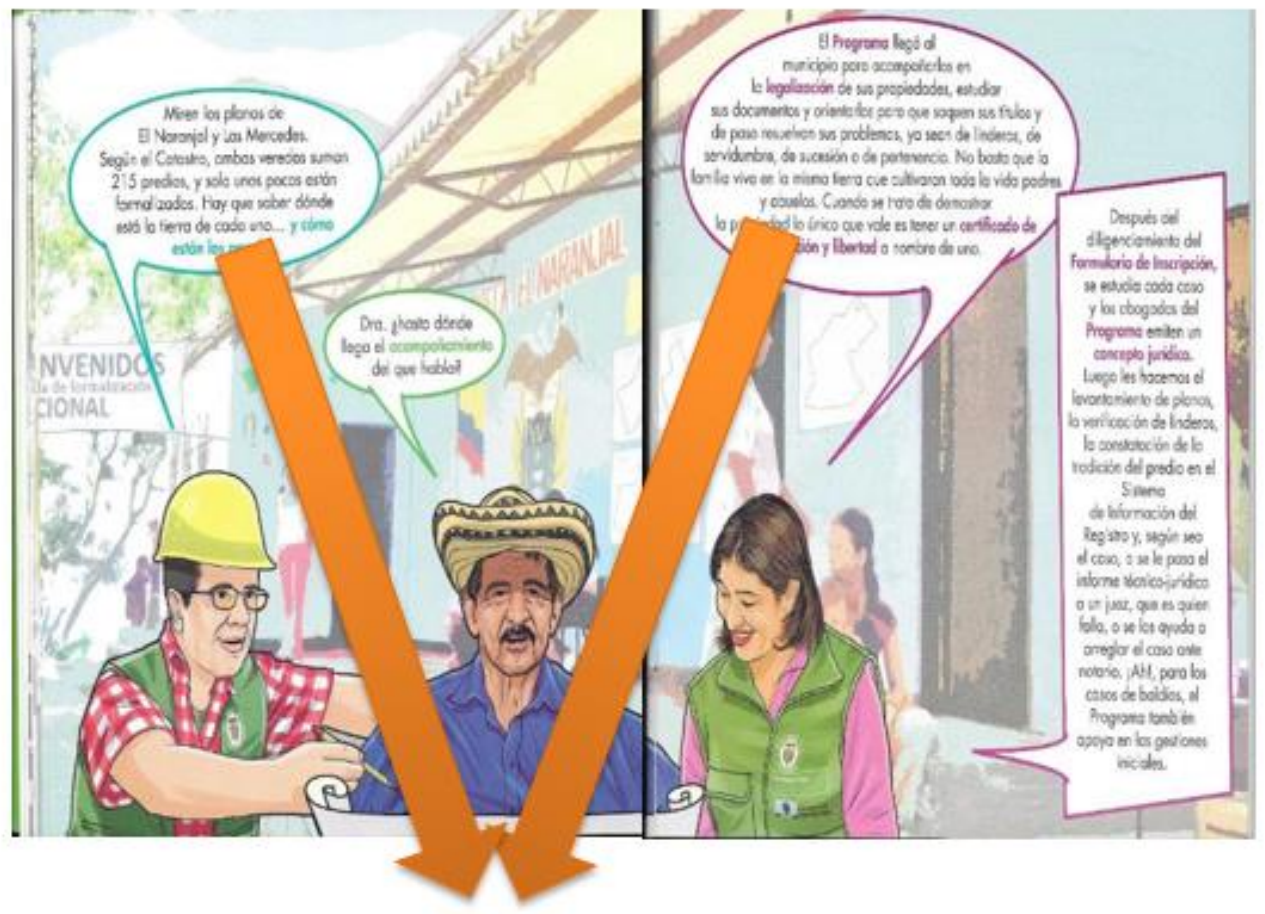

El lenguaje de la campaña desde el punto de vista lingüístico y comunicativo hacen parte del ámbito pragmático, a través de la cual se busca plasmar los actos del habla y, en general, realizar acciones con palabras. A través, del lenguaje se busca la atención de los destinatarios prefijados, mediante un discurso atrayente que genere interés, en el que se integran elementos persuasivos que generen deseo y que necesariamente acabe en la acción de obtener ese objeto de o de sumarse a esa idea.

Fuente: Ministerio de Agricultura y Desarrollo Rural (2012) 
El desarrollo estrategia socio - comunicativa permitió constatar el compromiso que se generó entre el Ministerio de Agricultura y Desarrollo Rural, la Universidad Santo Tomás y la Alcaldía de Ramiriquí en el desarrollo y puesta en marcha de la estrategia socio comunicativa sobre la formalización de tierra. En este sentido, se puede establecer que el proceso como tal estuvo a la altura de una estrategia de esta magnitud; a través de la cual el componente de comunicación para el desarrollo de las comunidades logró su cometido, gracias a que, se utilizó un proceso acorde a la población a la cual se dirigió, integrando, además aspectos como desarrollo y cambio social.

Lo anterior, afianzado en el hecho que la "comunicación para el cambio social ve en la comunicación un vehículo para catalizar procesos de cambio, empoderar individuos, fortalecer comunidades y liberar voces que no han sido escuchadas previamente" (Rodríguez, Obregón y Vega, 2002, pág. 25), tal como sucede con la población receptora del programa de formalización de tierras en Ramiriquí - Boyacá; de la cual emergieron una serie de situaciones que llevaron a que la estrategia tuviera un desenlace poco favorable; en cuanto a que, la misma tuvo una gran acogida y respuesta inmediata por parte de la ciudadanía ramiquireña, lo que ocasionó que la infraestructura y capacidad del municipio para atender las reclamaciones colapsara, generando con ello el inconformismo por parte de la población frente a una estretegia que prometía iba a solucionar del todo el tema de formalización de tierras.

Por su parte, la cartilla fue muy bien acogida por los campesinos, debido a que la pudieron entender con facilidad, les gustó la presentación porque reflejaba la realidad en la que viven, además que la entrega estuvo previamente dirigida por una funcionaria del Ministerio de Agricultura, a quién le hicieron las respectivas preguntas, en especial orientadas al tiempo, costos, y a cómo se iba a llevar a cabo el proceso. Por último, todo lo expuesto se resume en la tabla 
Tabla 6. Resumen de la estrategia - socio comunicativa

\begin{tabular}{|c|c|}
\hline CRITERIO & ALCANCE \\
\hline Lenguaje & $\begin{array}{l}\text { Cómo se pudo observar en el análisis de la estrategia, figura } 9 \\
\text { el lenguaje utilizado fue el apropiado, en el cual se tuvo en } \\
\text { cuenta la población a la que iba dirigida la estrategia. }\end{array}$ \\
\hline Discurso & $\begin{array}{l}\text { También fue claro, coherente y preciso frente a mostrar la forma } \\
\text { como las personas podían comenzar su proceso de } \\
\text { formalización de tierras. }\end{array}$ \\
\hline Población & La población fue la pertinente \\
\hline Guion & $\begin{array}{l}\text { El guion de la estrategia socio - comunicativa fue el preciso, } \\
\text { además, si se tiene cuenta que fue muy bien trabajado por el } \\
\text { Ministerio de Agricultura (2102) (2013) }\end{array}$ \\
\hline Pieza más adecuada & $\begin{array}{l}\text { La estrategia socio - comunicativa, solo tuvo dos piezas un } \\
\text { plegable y la cartilla. La más conveniente fue la cartilla, la cual } \\
\text { requiere ser mejorada, en cuanto a que, debe presentar los } \\
\text { escenarios opuestos y las acciones a seguir. }\end{array}$ \\
\hline
\end{tabular}

Fuente: autor

\subsubsection{Los logros y dificultadesen la implementación de la estrategia socio - comunicativa propuesta por el Ministerio de Agricultura con relación a la formalización de tierras en el municipio de Ramiriquí - Boyacá.}

Los pros de la estrategia socio - comunicativa albergo aspectos fundamentales de la comunicación para el cambio social, como, por ejemplo: "Evitar que las personas sean simplemente objetos de cambio, convirtiendo más bien a las personas y comunidades en agentes de su propio cambio" (Rodríguez, Obregón y Vega, 2002, pág. 25) debido a que la comunidad a través del proceso comunicativo tuvo que comprender el proceso al que se iba a acercar, la forma como debía hacerlo y los beneficios que todo este proceso traería para la comunidad.

"Evitar la simple transmisión de información por parte de expertos técnicos y colocar esa información en contexto de diálogo y debate" (Rodríguez, Obregón y Vega, 2002, pág. 25) situación que fue muy bien abordado en la estrategia socio - comunicativa, gracias a que la misma tuvo un cuidado minucioso de utilizar en todo su contexto la información necesaria, 
conforme a la población que iba dirigida y las particularidades de la misma. En cuanto a “evitar que expertos técnicos de agencias externas dominen y guíen el proceso y lograr que las personas afectadas por los problemas desempeñen un papel más importante” (Rodríguez, Obregón y Vega, 2002, pág. 25) en este punto la estrategia propuesta por el Ministerio de Agricultura (2013) logró vincular de forma adecuada a la población campesina, quienes por sus particularidades tienden a evitar el protagonismo de sus acciones, pero que dadas las necesidades del proceso no pueden ser ajenos a ésta.

Aspectos todos que contribuyen a la "participación política que hace referencia a los deseos de los ciudadanos ordinarios de influenciar la política y sus resultados en una sociedad, o las decisiones que afecta los asuntos públicos” (López, 2016, pág. 55). Siendo relevantes para la investigación: La participación ciudadana, que generan el involucramiento social, que se manifiesta en que la población debe estar atenta de los temas que les afecten, como la formalización de tierra. Compromiso ciudadano, son las actividades que los ciudadanos realizan para influir en circunstancias sociales como las que emergen de las necesidades propias del municipio como la formalización de predios.

En cuanto a los contras, como ya se ha expresado existe la clara necesidad de generar un diagnóstico que permita evidenciar las necesidades propias del municipio en materia de formalización. Así, lo afirma la Gobernación de Boyacá (2014) a través de su página web, frente a la noticia que cuestiona si se requiere la implementación de mecanismos administrativos para consolidar los procesos. Por la importancia de la noticia, se transcribe textualmente:

... La estructura de la tenencia de la tierra en este departamento no es de minifundios es de microfundios y de los 550.000 predios rurales que hay en Boyacá el $70 \%$ tienen algún carácter de informalidad.

De los 380.000 predios correspondientes al 70\%, tienen algún perfil de informalidad, los restantes están en falsa tradición y eso permite que los que poseen esos terrenos no tengan acceso a los servicios del Estado, correspondientes a los financieros, públicos y de oferta institucional, por eso, para el departamento esta es una apuesta sin igual. 
En este sentido, el Gobernador de Boyacá comprometió en el contrato plan 40.000 millones de pesos para iniciar el proceso, pero son insuficientes debido a que, se debe formalizar un $10 \%$ del total de la informalidad en todas sus manifestaciones, por lo menos 50.000 predios, que a los precios de hoy significan más de 120.000 millones de pesos y la apuesta del departamento por lo pronto es de 40.000 .

El proceso es complejo, para formalizar los 2.730 predios de Ramiriquí, no basta con el juzgado municipal, no basta con la oficina de registro, se necesitan más oficinas de registro así sea de carácter temporal y muchos más juzgados para atender las demandas masivas que va a requerir el esfuerzo no solamente de Ramiriquí sino de todo el país, y no existe esa institucionalidad, como si esto fuera poco, también se necesitan topógrafos para realizar los levantamientos de rigor, los pocos que quedan se los lleva la industria petrolera, No hay ingenieros catastrales, los desarrollos catastrales están rezagados, el Agustín Codazzi no cuenta con los funcionarios que se requieren para instrumentar el proceso. Una buena propuesta para el departamento de Boyacá se frustra porque la institucionalidad nunca había convocado el requerimiento que implica en términos cuantitativos miles de millones de pesos (Gobernación de Boyacá, 2014, pág. 1)

Se puede establecer que los contras, en parte obedecen a que dentro del riguroso modelo metodológico propuesto por el Ministerio de Agricultura (2013) hizo falta una mayor claridad en la forma como se debe realizar la estrategia socio-comunicación.

Aspecto que lleva a establecer que la propuesta de la estrategia socio - comunicativa está orientada a la comunicación para el cambio social que es estrictamente participativa y dialógica, la cual integra tres aspectos esenciales: Es de largo plazo, es colectiva y masiva y busca la persuasión frente a la formalización de tierras, como una forma de responder a la línea de investigación propuesta diálogos posibles entre comunicación gobierno y ciudadanía, que tiene como eje central la "existencia del otro" que se convierte en el fundamento de su acción. Así, se da la trilogía entre: Municipio - Formalización de predios - ciudadanía.

Como se pudo observar en el desarrollo de la investigación, existió un amplio y significativo esfuerzo por parte del Ministerio de Agricultura (2013) en la estrategia socio - comunicativa desarrollada en Ramiriquí entorno a la formalización de tierras, pero que requiere de un fortalecimiento para que se logre el mayor número de casos exitosos. 
De esta forma, los pasos que el Ministerio de Agricultura debe tener en cuenta para que la estrategia socio - comunicativa tenga éxito son los siguientes:

1. Definición del tema de la estrategia: La definición del tema propuesto por el Ministerio de Agricultura (2012a) (2012b) es amplio y suficiente, orientado a legalizar aquellos predios que están en manos de las personas, pero que no poseen los títulos de propiedad - escritura pública - que les ofrezca la potestad de ejercer sus derechos, como por ejemplo adquirir créditos para su crecimiento económico. Sin embargo, a futuro se debe afianzar en la ley más reciente Ley 1753de 2015 por la cual se expide el Plan Nacional de Desarrollo 2014 2018, en donde se señala que la formalización de tierras de naturaleza privada reviste de gran importancia en materia de ordenamiento social de la propiedad para brindar seguridad jurídica en las relaciones sobre la tierra de los campesinos, fundamento para el desarrollo rural.

Ley que se ejecuta mediante el Decreto 2363 de 2015, a través del cual se creó la Agencia Nacional de Tierras, y se estableció la necesidad de actuar por oferta por medio de metodologías que logren llegar al territorio de forma planeada, articulada, participativa y pronta para que mediante la modalidad de barrido predial se solucionen los conflictos sobre la tierra predio a predio, logrando con ello regularizar de forma integral, masiva y progresiva, las situaciones anómalas en tenencia y uso de la tierra. Aspecto que debe ser incluido por el Ministerio de Agricultura, debido a que, cuando se hizo la estrategia comunicativa esta normatividad no estaba vigente.

De esta forma, Neva (2014) define la formalización de tierras, a partir de lo dispuesto por la Dirección de Ordenamiento de la Propiedad Rural y Mercado de Tierras UPRA:

(...) regularización de la propiedad rural como el conjunto de estrategias, instituciones, normas y procedimientos encaminados a la promoción del acceso a la propiedad rural, que permite, de un lado, el saneamiento en situaciones jurídicas imperfectas de posesión material de bienes inmuebles, el otorgamiento de un título constitutivo de propiedad que corresponda a la forma de propiedad de que se trate, de origen público o privado, con el fin de garantizar seguridad jurídica en los derechos sobre inmuebles, propiciar el 
desarrollo sostenible y prevenir el despojo o abandono forzado de inmuebles (...) (pág. $34)$.

Se tiene entonces, que la formalización de tierras busca promover el crecimiento económico, como una forma de superar la pobreza en pro del cambio social que se orienta a la formación de una nueva generación de pobladores con una nueva economía y habitando en terrenos propios

2. Investigación sobre el tema: Este punto es quizás el más débil o inexistente, debido a que el Ministerio de Agricultura (2013) no hizo un diagnóstico que permitiera establecer las necesidades del municipio de Ramiriquí en materia de formalización de predios. Para tal fin, se debe hacer un inventario de tierras, indagar sobre cuales tienen problemas de dominio y así, tener claridad en el número de éstos.

Luego, se debe establecer la capacidad del Juzgado Civil Municipal para atender el número de casos que le lleguen, de acuerdo, al censo previamente realizado sumando la necesidad de personal que ayude al trámite procesal y los abogados que contrate el Ministerio o Municipio para tal fin, teniendo en cuenta que estos procesos se llevan a cabo en forma gratuita.

Teniendo claridad en este tema, se logrará una efectiva estrategia formalizadora de tierras. Es de aclarar que este fue el punto más débil de la estrategia socio - comunicativa que desbordó toda la capacidad logística como se explicó en el apartado en el cual se analizó la pieza socio - comunicativa.

3. Formular la meta de la estrategia: ¿Qué se espera lograr con la estrategia socio comunicativa? Lograr con la población meta la mayor cantidad de predios formalizados. La meta que tiene propuesta el Ministerio de Agricultura y la Agencia Nacional de Tierras a través del Estado es erradicar el mayor número de predios en la informalidad del municipio de Ramiriquí y demás municipios del país. "La esencia de la comunicación será informar sobre el Programa de Formalización de la Propiedad Rural, beneficios que reporta, y cómo acceder a él. Acorde con la particularización de los públicos objetivo se definen acciones, 
contenidos y herramientas de comunicación" (Ministerio de Agricultura y Desarrollo Rural, 2012b, pág. 6) Aspecto, que se mejorará siempre y cuando en un nuevo proceso se realice el debido diagnóstico.

4. Formular o definir la población meta: La población meta son todas aquellas personas que tengan predios en la informalidad en Ramiriquí y demás municipios del país. Sin embargo, los objetivos propuestos por el programa para los lineamientos de la estrategia de comunicación, que en su totalidad son ocho (8), adolecen de grandes vacíos:

- Posicionar el Programa como la instancia estatal de referencia para la formalización de la propiedad rural;

- Divulgar entre las autoridades nacionales, regionales y locales los propósitos y bondades del Programa;

- Generar credibilidad con respecto a las entidades que intervienen en la formalización de la propiedad rural;

- Despertar interés entre los poseedores de tierra sin títulos de propiedad sobre los beneficios que reporta la formalización;

- Motivar a los poseedores de tierras sin título a formalizar y legalizar;

- Informar los lugares, procedimientos y requisitos para formalizar la propiedad;

- Movilizar orientar y acompañar a las comunidades de los municipios donde se valide y aplique el método de barrido predial y

- Fomentar en la comunidad rural la cultura de formalización (Ministerio de Agricultura y Desarrollo Rural, 2012b, pág. 4)

El cumplimiento de estos objetivos requiere un pleno y amplio conocimiento de las necesidades de las personas para que la estrategia propuesta logré ser un éxito total. En especial, se debe afianzar lo referente a la credibilidad que deben tener las personas respecto a las entidades que intervienen en la formalización. Así, en una nueva etapa de la estrategia socio - comunicativa estos objetivos serán de fácil cumplimiento.

5. Investigación formativa: Esta fase fue abordada en la estrategia socio - comunicativa, debido a que el Ministerio de Agricultura y sus colaboradores como la Universidad Santo Tomás, tuvieron especial cuidado en identificar las particularidades del a población, que en su mayoría son campesinos; razón por la cual, el proceso se hizo con visitas en los predios, cuñas radiales que los invitaba a las charlas para que se les explicara el proceso en el que se iban a incursionar, carteleras y la cartilla la cual manejo un lenguaje acorde a la población 
como se señaló en el capítulo precedente. Este punto se podría afianzar, teniendo cuidado en llevar un registro minucioso de los predios visitados y de las charlas informativas, que den cuenta del número de personas que fueron informadas; esto permitirá contrastar la información que tienen las entidades oficiales como el Instituto Geográfico Agustín Codazzi con las visitas y las charlas realizadas relacionada con los predios sin formalizar.

6. Diseño de mensajes: Esta parte también está muy bien diseñada por la estrategia socio comunicativa, pues como se mostró en el apartado de análisis, los mensajes son los adecuados, con el lenguaje señalado. Quizás debería ampliarse en cuanto a:

- Explicitar el paso a paso de cómo se va a dar la formalización que se encuentra en la cartilla, pero que, de no darse, brindarse la solución. Por ejemplo, sí el juzgado no está en capacidad de recibir su proceso, indicarle que puede hacer, si lo atienden en otro municipio o en cuánto tiempo puede volver. No se trata de dar respuestas a todas las inquietudes, pero si a aquellas que se susciten con el simple hecho de comenzar el proceso de formalización.

- Sumado a las características que debe tener el mensaje en términos de: atracción, comprensión, involucramiento, aceptación, inducción a la acción que la estrategia informativa las tiene todas, se debe sumar, orientación, por lo especial de la población siempre debe haber un mensaje que lo oriente a recibir una respuesta que comprenda y no le genere falsas expectativas.

7. Estrategias de medios. Este punto también fue muy bien abordado por la estrategia socio - comunicativa, elaborada por el Ministerio de Agricultura la difusión que se le dio fue tal, que eso fue lo que ocasionó que el municipio colapsara.

(...) Los encuentros y reuniones con las autoridades y actores locales que intervienen en el proceso, deberán estar acompañados de estrategias de comunicación a través de los medios de comunicación masiva efectivos en la zona de trabajo, como cuñas radiales, perifoneo, avisos y carteleras en puntos visibles, entre otros (...) (Ministerio de Agricultura y Desarrollo Rural, 2012a, pág. 27) 
Este punto se puede superar siempre y cuando se logré contar con la capacidad logística del municipio para atender las solicitudes, que integre la infraestructura necesaria para atender las solicitudes, bien sea, directamente en el municipio u otros lugares, como por ejemplo Tunja por ser la capital de Boyacá.

8. Validación del mensaje: Como lo demostró el Ministerio de Agricultura (2012a) el mensaje utilizado fue debidamente validado.

(...) Es importante lograr una articulación institucional, en la que las entidades territoriales reconozcan la importancia que tiene la formalización de la propiedad para el desarrollo rural integral y se apersonen del proceso; en este sentido, el alcalde juega un papel fundamental como vocero y portavoz del proceso en el municipio para que a este esfuerzo se sumen los actores locales, entidades, instituciones y la población rural.

Muchos de los procesos relacionados con temas prediales, sobre todo en el sector rural, omiten dentro de la su estrategia de implementación la labor social, por eso muchos de estos procesos presentan problemas en la presentación de resultados, pues nunca se le explicó al campesino las características del proceso, las posibles repercusiones, las ventajas, las desventajas y la manera en que puede participar del proceso (...) (Ministerio de Agricultura y Desarrollo Rural, 2012a, pág. 26)

Este aspecto ha sido muy bien desarrollado como se demostró en la estrategia socio comunicativa la cual fue un éxito, y parte de éste es el mensaje dado a los campesinos sobre la formalización; quizás lo único a mejorar sería integrar las soluciones frente a las diferentes posibilidades que se den dentro del proceso de formalización; por ejemplo: Saber sí el abogado es gratuito o no, o en qué casos lo es; informar sí el municipio se colapsa, si otro municipio tiene la jurisdicción para atender los casos, como sería el caso de Tunja; lo referente a costos como notificaciones, edictos, entre otros.

9. Elaboración final de los mensajes: Este aspecto también fue muy bien abordado como se señaló en el punto seis y debe ser ampliado como se sugirió en el punto anterior.

10. Implementación de la estrategia socio - comunicativa: Fue también un proceso muy bien desarrollado. Su lanzamiento fue en la plaza central del municipio, en compañía de las 
autoridades municipales, entre otras. Para una nueva estrategia se puede utilizar el mismo mecanismo.

11. Investigación sumativa: Es la evaluación de la implementación e impacto de la estrategia, que al igual que el punto 2 , es inexistente. Se requiere entonces aplicar una propuesta formativa o de diagnóstico base, que permita visibilizar todo el contexto de la estrategia que se va a realizar.

Los lineamientos propuestos se sustentan en la estrategia socio - comunicativa; por eso, cumplen un papel de apoyo para fortalecer aquellos aspectos débiles y así dar continuidad a la estrategia propuesta, que no permita duda alguna. En este sentido, se deben redefinir los tiempos de implementación, los costos teniendo en cuenta el diagnóstico que se requiere, el recurso humano calificado tanto para el re - diseño de la estrategia como para ejecutarla, recursos tecnológicos y manejo de indicadores que permitan medir la efectividad de la estrategia. 


\section{Conclusiones y recomendaciones}

\subsection{Conclusiones}

Los lineamientos de la estrategia socio - comunicativa utilizada para dar a conocer el programa de formalización de tierras en Ramiriquí Boyacá, tuvo un gran impacto, por ser este municipio escogido como pionero. Sin embargo, las acciones ejercidas se quedaron cortas frente a la envergadura del programa, llevando a que éste no superara el año de vigencia, exigiendo con ello, una transformación en los lineamientos propuestos que

garanticen, no solamente una efectiva comunicación, sino que esta se ciña estrictamente a la realidad; es decir, a lo ofrecido por el Ministerio de Agricultura, la gobernación de Boyacá y la alcaldía municipal.

\subsubsection{Objetivos específicos}

En lo concerniente a los objetivos propuestos en la investigación se observó que, si bien se logró analizar la estrategia socio - comunicativa, en cuanto a que se logró recopilar los datos necesarios para establecer la importancia y necesidad de la implementación de ésta en el municipio de Ramiriquí; sin embargo, en lo concerniente al alcance del desarrollo y cambio social de la comunidad con el programa de formalización de tierras, continua siendo un proceso en ascenso, debido a que, como se explicó a lo largo de la investigación, la realidad del municipio desbordó por completo la infraestructura propuesta para ejecutar el programa. Esto obedeció a que no se llevó a cabo un diagnóstico previo que permitiera evidenciar las 
necesidades de la comunidad en el trabajo propuesto; por ello, las historias de éxito se han dado en el 2017, pues el programa no logró sobrevivir los dos años, quedando el desconcierto en la comunidad campesina con relación a lo ofrecido y no logrado.

En cuanto, al objetivo que buscó identificar la estrategia socio - comunicativa que se implementó en el municipio de Ramiriquí - Boyacá sobre la formalización de tierra, se logró su desarrollo, por medio del cual se pudo identificar un proceso claro, secuencial y efectivo como se muestra en el desarrollo del trabajo. Sin embargo, se lograr establecer que hizo falta un componente esencial, que fue el diseño de una estrategia comunicativa acorde a las necesidades y exigencias de las mismas, aspecto que va a permitir determinar las necesidades logísticas de la propuesta informativa y de esta forma se hubiera evitado el colapso al que llegó. Si se hubiera tenido la información pertinente sobre las verdaderas necesidades del municipio se habría podido adaptar la infraestructura necesaria para llevar a feliz término el programa realizado; es decir, se hubiera podido abrir un juzgado alterno, contratar más personal, contar con los abogados que conozcan de esta clase de procesos, conocer el valor de cada proceso, generar los insumos necesarios para que por lo menos de lo propuesto se hubiera saneado el cincuenta por ciento, y no tener una realidad que solamente genera en la comunidad campesina la sensación de incertidumbre y el malestar para volver a creer en lo propuesto por el gobierno municipal.

De ahí que, la incidencia en el desarrollo y cambio social de la comunidad, a partir de la estrategia socio - comunicativa que se utilizó en el proyecto formalización de tierras en Ramiriquí Boyacá; se tiene que la respuesta es ambivalente, debido a que, con la acogida que tuvo la estrategia socio - comunicativa, se puede decir, que sí existió un alto nivel de apropiación y obviamente incidió en el desarrollo y cambio social, en el sentido, que al haber tenido tanta acogida la estrategia, se veía que el resultado iba orientado al crecimiento del municipio; hasta ahí, todo bien; pero como en la realidad el programa no se dio, por ende, ni el desarrollo ni el cambio social se generó; por lo menos no en la forma deseada.

Razón por la cual, el tercer objetivo orientado a los logros y dificultades de la estrategia socio - comunicativa, muestra claramente el vacío que se presentó en la estrategia. Esto 
genera una ruptura entre la comunicación, el cambio social y la participación de la comunidad siendo casi inexistente en cuanto a las necesidades propias de ésta. Lo anterior debido a que no se encuentra un proceso comunicativo asertivo, en cuanto a orientar, como se estableció en la propuesta. La estrategia socio - comunicativa se centra en informar y convocar, informar y sensibilizar y convocar sobre la importancia de formalizar; pero, no introduce un proceso dialógico que le dé solución frente a las situaciones desorientadoras, como se señaló en la propuesta.

A pesar de que la estrategia informativa plantea a quién va dirigida la información, los objetivos propuestos son confusos; debido a que no logra visibilizar el paso a paso requerido para esta clase de procesos.

Con la propuesta de la estrategia socio - comunicativa formulada se busca posicionar el programa de formalización de tierras ante las audiencias de interés mediante mensajes y actividades estratégicas. Y así, lograr una participación asertiva por parte de la población, en pro de comprender el alcance de la estrategia socio -comunicativa. Razón por la cual es importante fortalecer el área de comunicaciones, que debe incluir la conformación de un grupo interdisciplinario, conformado por personal calificado y así fortalecer la estrategia socio - comunicativa.

Finalmente, la formalización de tierras en la fase del posconflicto que comienza a evidenciarse en el país, debe ser objeto de una reforma agraria, como una forma de responder a uno de los mayores problemas que ha tenido el país en materia de concentración de la propiedad, en parte, por el desconocimiento que existe frente a la propiedad heredada del campesino, en parte al desplazamiento forzado que se agudizó con la irrupción primero del narcotráfico y luego con el fenómeno paramilitar, a la apropiación ilegal de los predios por parte de los terratenientes, al uso inadecuado de las mismas tierras - con vocación agrícola pero dedicadas al levante de ganado y a la producción de forrajes o últimamente, a la masiva concesión de títulos mineros a las multinacionales, entre otras. 


\subsection{Recomendaciones}

Se debe generar un trabajo colaborativo entre las entidades del Estado y las organizaciones privadas que se quieran hacer parte del proceso para que se logré una trazabilidad que permita enfrentar cualquier inconveniente que se presente tanto en el diseño como en el desarrollo mismo del programa; de esta forma, se logrará una sola voz que indique todos los aspectos relacionados con la formalización de tierras y que el campesino no quede mal informado, desinformado o confundido, sino que de entrada tenga claridad de lo que propone el Estado. Es decir, que la estrategia socio - comunicativa satisfaga sus expectativas y sea verdadera, sobre todo en esta época de la llamada post verdad en la que los Medios han abierto espacio a la mentira como mecanismo de control social.

Queda también como tarea de política pública urgente, hacer del censo agrario una política de Estado, capaz de sortear las suspicacias que se han tendido desde los enemigos de los acuerdos de paz con las FARC, que lo presentan como una exigencia de la guerrilla para despojar a los finqueros de sus tierras e imponer un modelo colectivista de la propiedad.

Una estrategia comunicacional de respaldo a un proyecto de alto impacto social deberá tener muy en cuenta a futuro la diversidad cultural del país, de modo que platearla desde un escritorio en Bogotá resultará siempre contraproducente, habida cuenta de la gran complejidad del componente humano que habita las distintas regiones del país.

Finalmente es importante que desde la academia se continúe con estudios como éste, en maestría o doctorado respondiendo a un aspecto en boga hoy cual es la Responsabilidad Social Universitaria RSU, a través de los cuales se compartan experiencias dentro o fuera del país. Responsabilidad Social Universitaria en su triple enfoque Gerencial, transformacional y normativo. El primero que atiende al impacto del quehacer universitario hacia dentro con la rendición de cuentas; el segundo, transformacional, pues revisa el desempeño universitario para lograr una sociedad más justa y el último, el normativo, que busca el desarrollo de unos sistemas de valores desde la norma y todo en función de “sociedades humanistas, equitativas y solidarias” (Cortina, 1994, pág. 24). 


\section{Bibliografía}

Albán, A. (enero - junio de 2011). Reforma y contrareforma agraria en Colombia. Economía Institucional, 13(24), 327 - 356.

Alcaldía de Ramiriquí. (8 de mayo de 2014). Formalización de predios. Obtenido de ramiriquiboyaca.gov.co: http://www.ramiriqui-

boyaca.gov.co/noticias. $\operatorname{shtml}$ apc $=\mathrm{ccx}-1-\& \mathrm{x}=2772070$

Alcaldía Municipal de Ramiriquí. (2015). Plan Básico de Ordenamiento Territorial Síntesis Obtenido de http://cdim.esap.edu.co/BancoMedios/Documentos\%20PDF/sintesis_ramiriqu\%C3 $\% \mathrm{AD}\left(24 \_p a g \_221 \_k b\right) . p d f$

Ámbito Jurídico. (22 de junio de 2015). Así va el proceso de formalización de la propiedad $\begin{array}{llll}\text { rural Colombia. } & \text { Obtenido de }\end{array}$ http://www.ambitojuridico.com/BancoConocimiento/Ambiental-yAgropecuario/asi-va-el-proceso-de-formalizacion-de-la-propiedad-rural-encolombia

Araújo, G. (2011). Política integral de tierras. El desafío de la formalización y restitución a despojados. Bogotá. D.C.: Corporación Pensamiento Siglo XXI.

Arráez M, Calles, J y Moreno, T. (2006). La hermeneútica: una actividad interpretativa. Sapiens, 7(2), 171 - 181.

Bertoni, Castelnovo, Cuello, Fleitas, Pera, Rodríguez y Rumeau. (2011). ¿Qué es el desarrollo? ¿Cómo se produce? ¿Qué se puede hacer para promoverlo? Montevideo: Comisión Sectorial de Enseñanza.

Caracol Radio. (4 de junio de 2017). Habitantes de Ramiriquí, Boyacá , recibieron títulos de propiedad de sus tierras. Obtenido de http://caracol.com.co/emisora/2017/06/04/tunja/1496584595_513035.html

Carvajal, B. (2011). Apuntes sobre desarrollo comunitario. España: Eumed.net. Castillo, O. (2008). Paradigmas y conceptos del desarrollo rural (2 ed.). Boggotá, D.C: Pontificia Univesidad Javeriana. 
Centro Nacional de Memoria Histórica (CNMH). (2013). La política de reforma y tierras en Colombia: esbozo de una memoria institucional. Bogotá D.C.: Imprenta Nacional de Colombia.

Chaves, I. (2012). Comunicación para el cambio social. Universidad, sociedad civil y medios. Madrid: Catarata.

Chaves, J. (2010). La comunicación para el desarrollo desde las ONGD: Una aproximación teórica y una muestra práctica. Madrid: Académica española.

Cortina, A. (1994). Ética de la empresa. Claves para una nueva cultura empresarial.Madrid: Trotta.

Dorner, P. (1972). Reforma agraria y desarrollo económico. Madrid: Alianza Universidad. Escobar, A. (2012). Una minga para el postdesarrollo: lugar, medio ambiente y movimientos sociales en las transformaciones globales. Bogotá, D.C: Ediciones desde abajo.

Fondo Internacional de Desarrollo Agricola. (10 de 5 de 2007). misionrural.net. Obtenido de Estrategia de comunicación para incentivar la participación de los usuarios del programa en espacios de seguimiento y evaluación participativos del programa desarrollo de las oportunidades de inversión y capitalización de los activos de las microempresas

http://misionrural.net/observatorios/oportunidadesrurales/documentos/ESTRATEG IA\%20DE\%20COMUNICACIONE\%20PROGRAMA\%20OPORTUNIDADES\% 20RURALES.pdf

Gadamer, H. (1995). El inicio dela filosofía occidental. Barcelona: Paidos.

García, A. (1967). Reforma agraria y economía empresarial en América Latina. Santiago de Chile: Icira.

Gobernación de Boyacá. (20 de mayo de 2014). Boyacá pionera en legalización de predios. Obtenido de http://www.boyaca.gov.co/prensa-publicaciones/noticias/2642boyac\%C3\%A1-pionera-en-legalizaci\%C3\%B3n-de-predios

Gobernación de Boyacá. (02 de Septiembre de 2015). En 11 municipios de Boyacá ya se está realizando proceso de legalización de predios. Obtenido de http://www.boyaca.gov.co/prensa-publicaciones/noticias/5408-en-11-municipios- 
de-boyac\%C3\%A1-ya-se-est\%C3\%A1-realizando-proceso-delegalizaci\%C3\%B3n-de-predios

Gómez, B. (2011). La tenencia de la tierra y la reforma agraria en Colombia. Verba $\operatorname{Luris}(25)$.

Gumucio, A. (Enero-Junio de 2011). Comunicación para el cambio social: clave del desarrollo participativo. Signo y Pensamiento, 30(58), 26-39.

Hernández S, Fernández C y Baptista L. (2010). Metodología de la Investigación (5 ed.). México: Mc Graw Hilll.

Holguín, M y Rodríguez, J. (2015). Alcances de la asociatividad territorial como eje de desarrollo local y regional, para los municipios del Valle de Tenza, en el Departamento de Boyacá. Boyacá: Universidad Nacional de Colombia.

León, J. (2006). La economía rrural en el Siglo XX: 1890 - 1940. Obtenido de http://www.iice.ucr.ac.cr/economiarurali.pdf

López, M. (5 de octubre de 2016). Mujeres dialogando: Comunicación participativa como disparador para la toma de conciencia. Memorias XIII Congreso Latinoamericano de Investigadores de la Comunicación. Reflexiones críticas desde América Laitna, $53-59$.

Luna, E. (2013). Tierras despojadas, ¿derechos restituidos? (Des) encuentros acerca del problema de la tierra en Colombia en un escenario de "justicia transicional". Medellín: Universidad de Antioquia.

Machado, A. (2013). Esbozo de una memoria institucional la política de reforma agraria y tierras en Colombia. Bogotá, D.C: Centro Nacional de Memoria Histórica.

Martínez, Y. (2015). La tenencia de la tierra, la política ambiental y el desarrollo sostenible: estudio de caso municipios de Ramiriquí y Sachica. (Tesis de Grado). Manizales: Universidad de Manizales.

Minagricultura. (8 de diciembre de 2015). Lanzamiento del programa en Ramiriqui . Obtenido de Formalización propiedad rural: http://formalizacion.minagricultura.gov.co/zonas-de-formalizaci\%C3\%B3nmasiva/lanzamiento-del-programa-en-ramiriqui 
Ministerio de Agricultura y Desarrollo Rural. (2003). Marco normarivo de las zonas de reserva campesina. Bogotá, D.C: Instituto Interamericano de Cooperación para la Agricultura - ICA.

Ministerio de Agricultura y Desarrollo Rural. (2009). Proyecto forestería y Agroforestería como alternativa para la sustitución de cultivos illícitos. Colombia: Minagricultura.

Ministerio de Agricultura y Desarrollo Rural. (2011). Proyecto de Ley general de tierras y desarrollo rural. Bogotá, D.C.: DNP.

Ministerio de Agricultura y Desarrollo Rural. (2012). Lineamientos estratégicos de comunicación programa formalización de la propiedad rural. Colombia: Minagricultura.

Ministerio de Agricultura y Desarrollo Rural. (7 de octubre de 2013). Resolución número 000347. Por la cual se adopta la guía metodológica para la formalización masiva de la propiedad rural por barrido predial. Bogotá, D.C.

Ministerio de Agricultura y Desarrollo Rural. (Enero de 2016). Dirección de Ordenamiento social de propiedad rural y uso productivo del suelo. Guía de formalización de la propiedad rural por barrido predial. Bogotá, D.C.

Mujica, Ch y Rincón, G. (2010). El concepto de desarrollo: posiciones teóricas más relevantes. Revista venezolana de gerencia(50), 240 - 320.

Muñiz, M. (2003). Estudio de caso en la investigación cualitativa. Obtenido de http://www.psico.edu.uy/sites/default/files/cursos/1_estudios-de-caso-en-lainvestigacion-cualitativa.pdf

Nogales, N. (agosto de 2006). Desarrollo rural y desarrollo sostenible. La sostenibilidad ética. Revista de Economía Pública, Social y Cooperativa(55), 7 - 42.

Peñaloza, A y Morella, O. (2005). Elaboración de instrumentos de investigación. Obtenido de https://nticsaplicadasalainvestigacion.wikispaces.com/file/view/guia+para+elabora cion+de+instrumentos.pdf

Pérez y Farah. (2002). Los modelos de desarrollo y las funciones del medio rural en Colombia. Cuadernos de Desarrollo Rural, 49, 9 - 27 .

Planeta Paz. (2012). La cuestión agraria en Colombia: tierra, desarrollo y paz. Memorias / Ciclo de conversatorios. 
Plaza, O. (1990). Cambio social y desarrollo rural . En B. Chirif A Manrique N y Quijandría, El problema agrario en deate (págs. 88 - 102). Perú: Centro de Estudios Rurales Andinos Bartolomé de las Casas.

Programa de las Naciones Unidas para el Desarrollo [PNUD]. (1990). Human Development report 1990. Colombia: Tercer mundo editores.

Ramiriquí Boyacá 1541 - 2007. (2007). Obtenido de http://ramiriqui-boyaca.gov.co/apc-aafiles/65386564666535386537376362343065/ramiriqu1-resea-final-1541-2007.pdf

Resolución 452. (2010). Por la cual se crea el programa de formalización de la propiedad rural y su unidad coordinadora. Bogotá, D.C: Ministerio de Agricultura y Desarrollo Rural.

Rodríguez, Obregón y Vega. (2002). Estrategias de comunicación para el cambio social.Colombia: Friedrich Ebert Stiftung.

Stake, R. (1994). Case studies. En N. Denzin, Handbook of qualitative research (págs. 236 - 247). London: Sage.

Tabares, A y Álvarez, A. (2014). La formalización de la propiedad rural en Colombia como un soporte de desarrollo local sostenible. Estudio de caso Municipio de Samaná, Caldas. (Tesis de grado). Manizales: Universidad Autónoma de Manizales.

Universidad Santo Tomás. (2014). Formato para inscripción - actualización, líneas de investigación. Bogotá, D.C: Universidad Santo Tomás.

Universidad Santo Tomas. (2015). Contrato de prestación de servicios profesionales suscrito entre la universidad Santo Tomas y Sonia Emilce Pineda Suesca. Bogotá, D.C: Gobernación de Boyacá - Universidad Santo Tomas.

Woods, P. (1987). La Escuela por dentro: la etnografía en la investigación. Buenos Aires: Páidos.

Youtube. ([video]. 2014). Entrega de títulos programa de formalización de propiedad rural en Ramiriquí. Obtenido de https://www.youtube.com/watch?v=zZzXJmNBYZU 


\section{Anexos}

\section{Anexo A: Guía de observación}

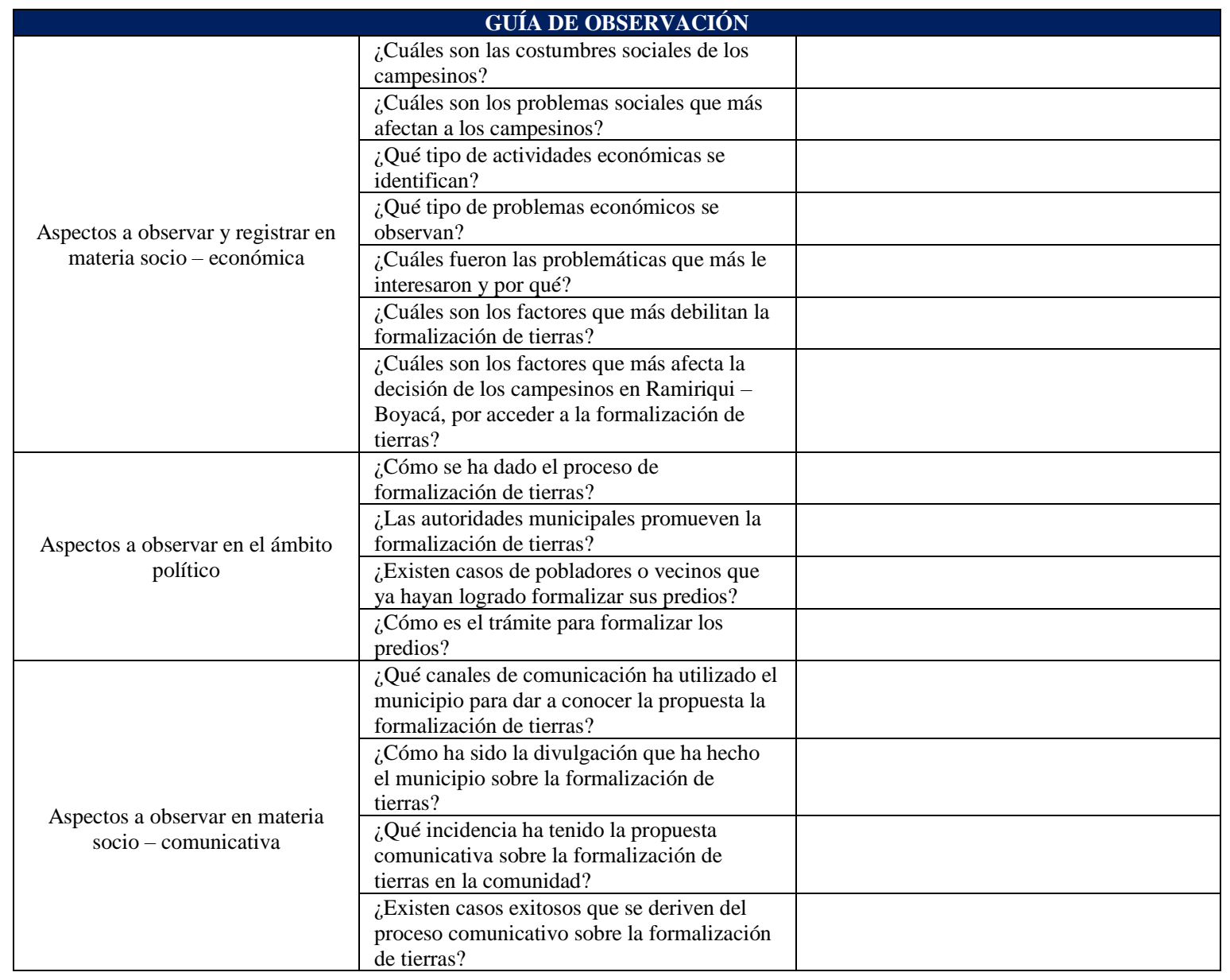




\section{Anexo B: Entrevista semiestructurada}

Buenos días y/o tardes:

La presente entrevista es de carácter exclusivamente informativo, la cual se realiza como apoyo al trabajo de investigación de la maestría en Comunicación, Desarrollo y Cambio Social, titulada: Análisis de una experiencia socio-comunicativa para el desarrollo rural y urbano: Formalización de tierras, Ramiriquí, Boyacá. De modo que, las apreciaciones acá señaladas no generan compromiso alguno con el tema tratado.

1. ¿Qué sabe sobre la formalización de tierras?

2. ¿Cuáles han sido las acciones ejercidas por la Entidad, en pro de fomentar la formalización de tierras?

3. ¿Cuál considera ha sido el mayor inconveniente para la formalización de tierras?

4. ¿Cuál ha sido el apoyo de las autoridades departamentales y nacionales en pro de promover la formalización de tierras?

5. ¿Cuáles ha sido el aporte de entidades no gubernamentales, como fundaciones, asociaciones o empresas privadas, en relación con la formalización de tierras? 


\section{Anexo C: Pasos para la formalización de tierras}

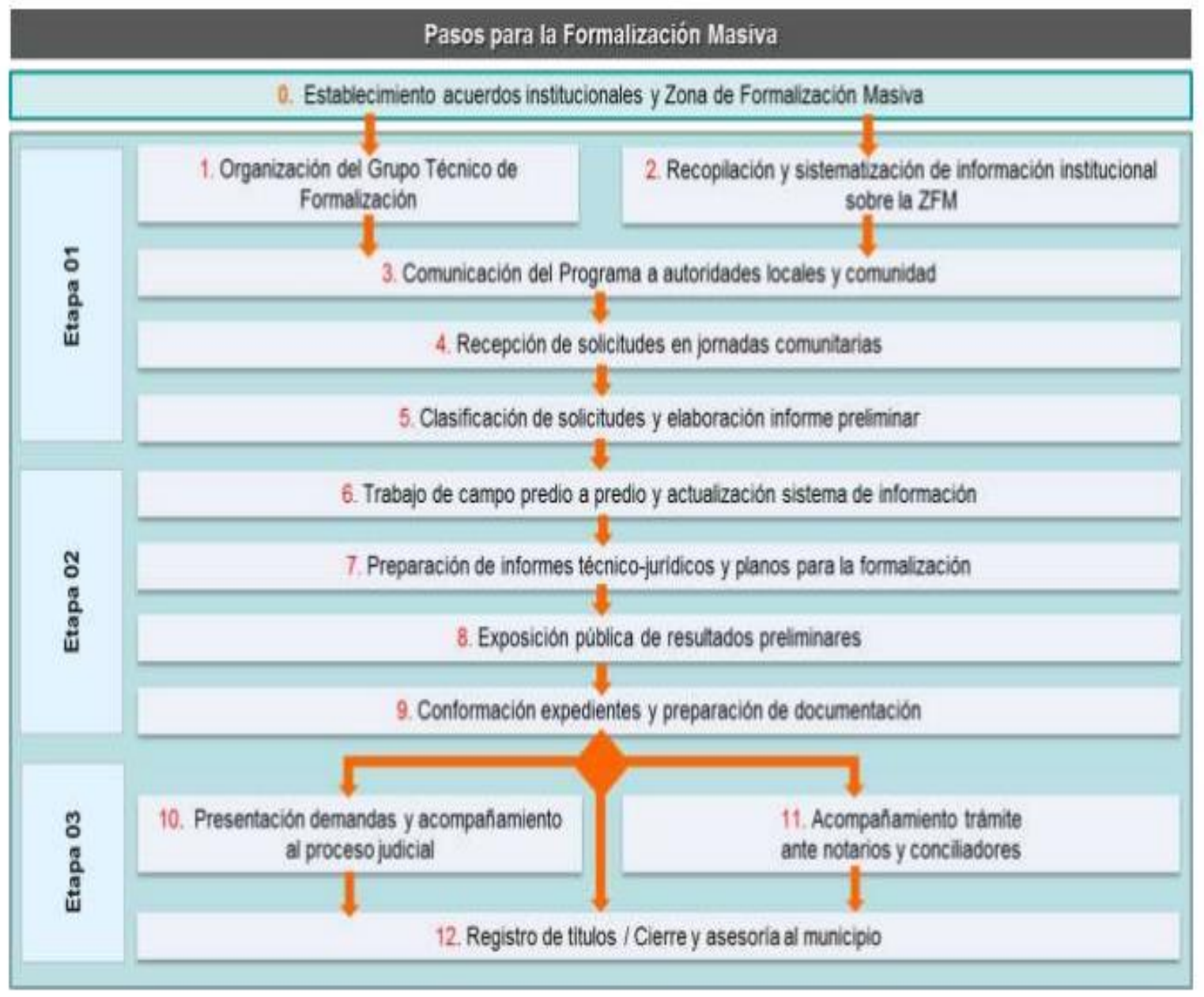

Fuente: Ministerio de Agricultura (2013) 



\section{Anexo D. Anunció en el periódico El Diario}

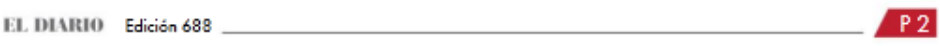

De un total nacional de 6.192 procesos de formalización iniciados en 2012, 1.003 correspondían

Primer año de formalización de propiedad rural

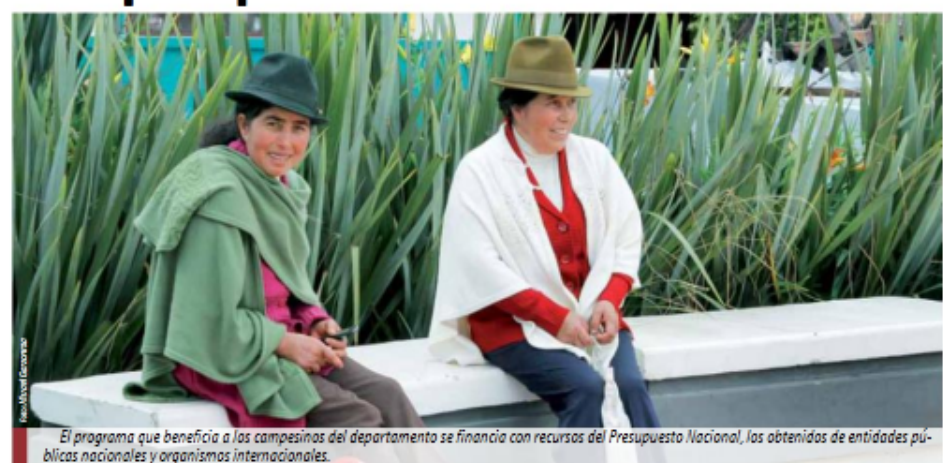

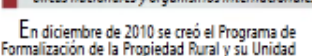

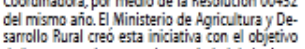

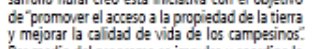

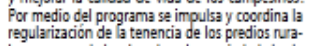

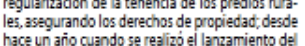

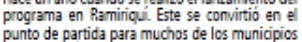

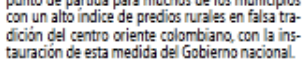
El paso a paso de ta
prealos en Ramiliquil

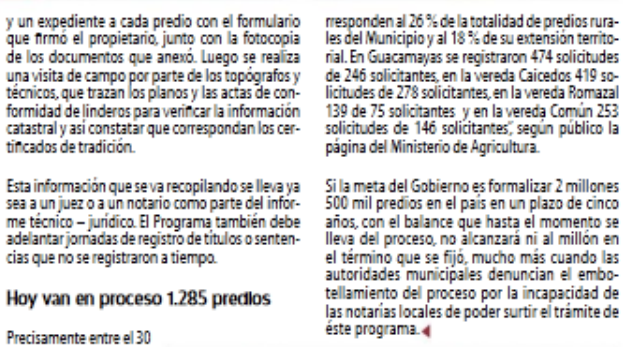

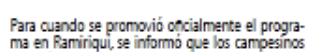
Contanan con las vertajas de legalizar SIS propoie-

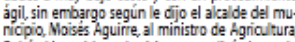

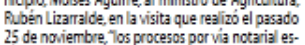

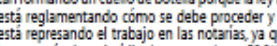
Aqui es donde entra la Unidsd Coordinadora

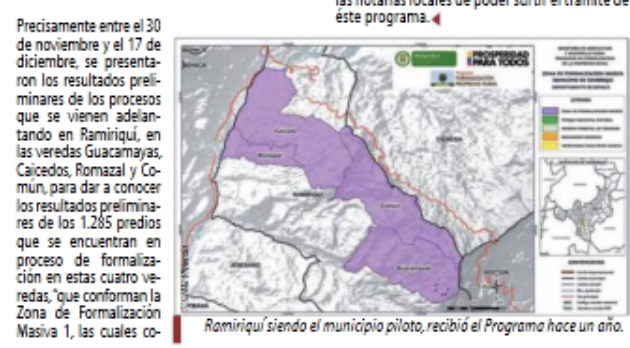

P3.

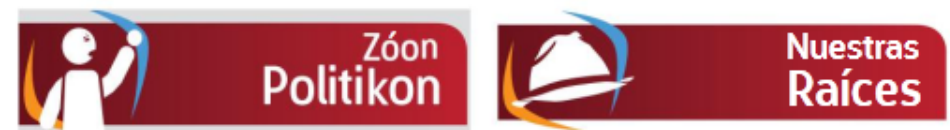

Plazo de inscripción de cédula

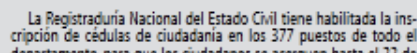

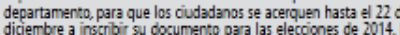

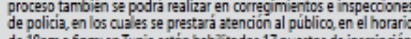

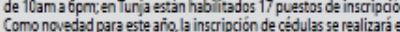

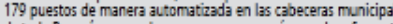

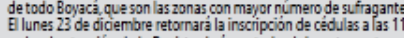
sedes de gención de la Registraduria en todo el I departamento y Cambios a última hora

Legado o l plazo ímite dago a los partidos poriticos para cambios

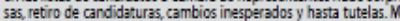

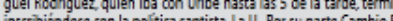

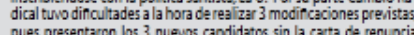

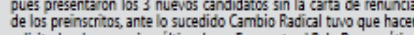

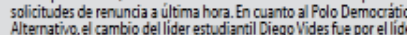

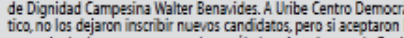

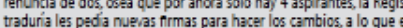

Nueva sangre de Rodrigo Rojas

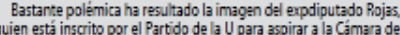
Riepresentrantes para el perioco 2014-2018. Con una bolsa de san-

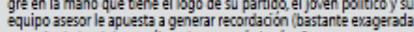

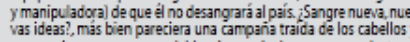

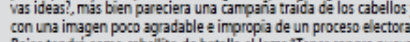

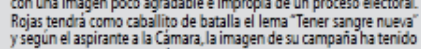
una acogidap postitia: iseríverdad

Todos quieren la Alcaldia de Paipa

Eso es lo que demuestra el nummero de aspirantera a ser el $\mathrm{man}$. datano del municicio. .rasta el momentio se ha conocido la inteColegio Juan Bautista Karia Vianney, Julio Camargo, ofl exalcalide

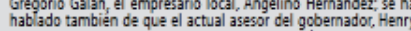

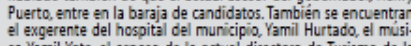

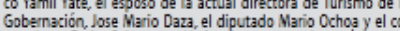
Mercante Pedro Sal amanca. Varios de estos nombres
"Lectura en familia"

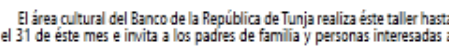

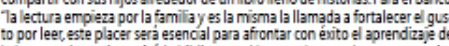

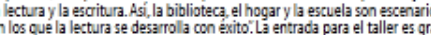

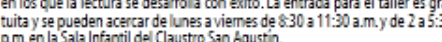
Fiestas de fin de año en Ramiriqui

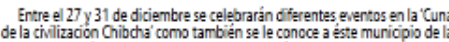

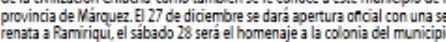

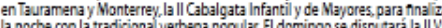

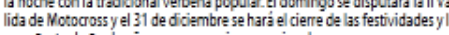
Solsticio Muisce

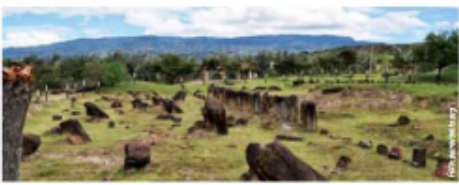

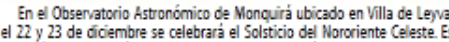

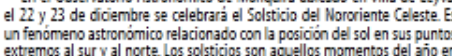

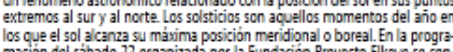

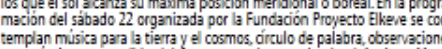

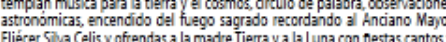

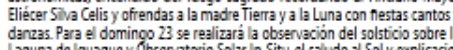

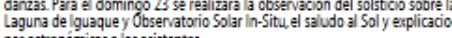
Ferias y Fiestas en Chit

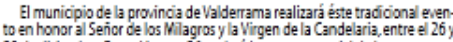
29 de diciembre: Fare

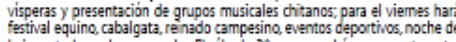

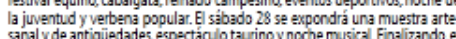

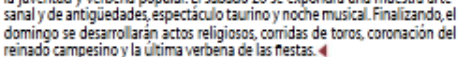

Una navidad llena de recogimiento y unión fam liar y un 2014 colmado de bendiciones para todos Diputado José Alberto Moreno Villamil. "Su voz en la Asamblea" 


\title{
Anexo E. Formato de notificación
}

\author{
FORMATO DE NOTIFICACIÓN
}

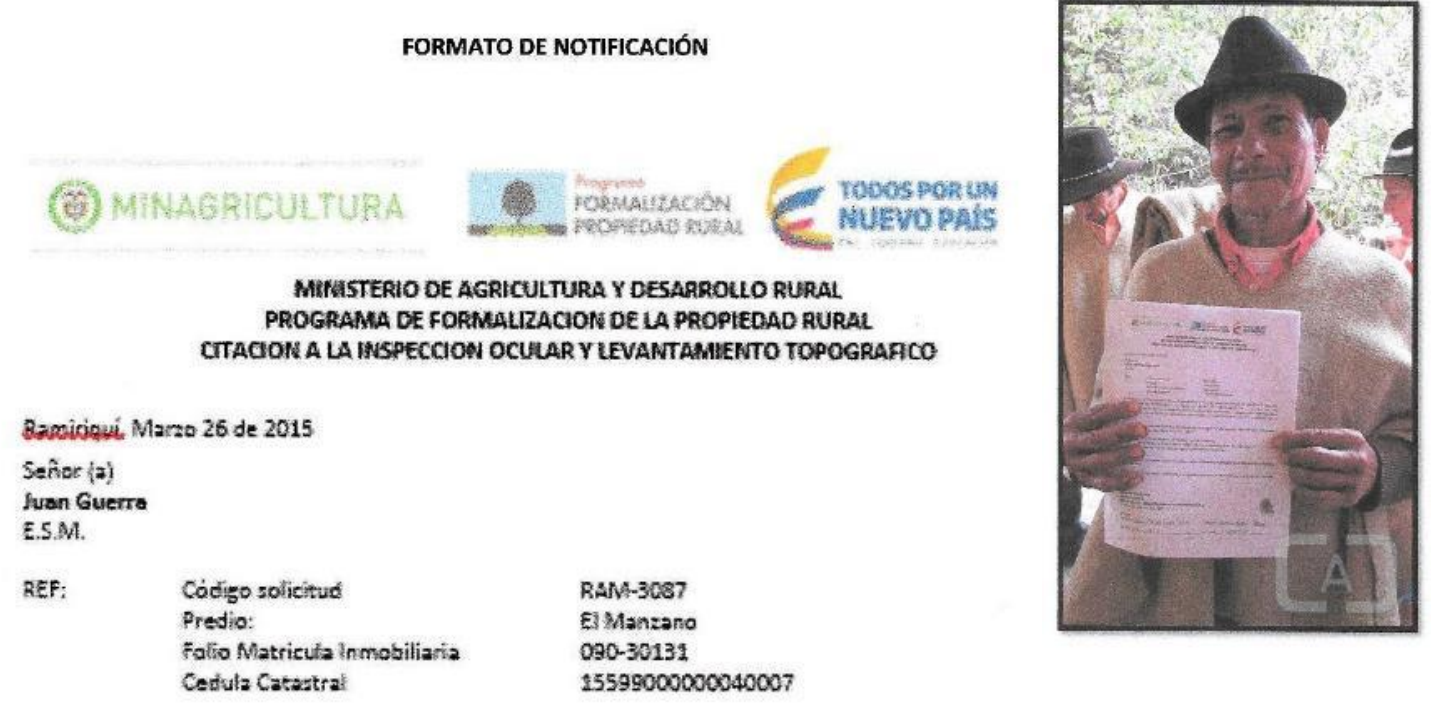

El programa de Formalizacićn de ta Propiedad Rural ha programado la jornada de INSPECCION OCULAR LEVANTAMENTO TOPOGRÁFICO, y toma de ACTA DE COUNDANCLA en su predio, el día 9 de Abril, en la quse se atenderá su solicitud $\%$ por lo tanto es necerario que usted participe junto con zus vecinos, tadoz sus colindantes y sus testigos quientes den fe de su situsción en relación con su predio.

Es necetario çue presente su cedula de ciudadania y los siguientes docupnentos para que sean entregados. Werifique el listado y haga llegar los que le taiten]

1 Fotocopia del regietro civil ce Matrimonia. (Si aplica)

2 identificación completa de los teatigos thombre, apelidos, dirección y teléfono).

3 Recibos de oervicio públicos (agua, luz) del preclio solicitente.

Alecuende que sin su presencia sará imposible realizar la IWSPECCION DCULAR Y LEVANTAMEENTO PREDLAL de su inmueble.

HOTA: La inasistencis a eta NSPECCICN se entender como faita de interés en la formalización de su predio

Corcial saludo.

Adriane Torazona

Coordinador E

PROGRAMA OE FORMAZZZCIDN OE LA PROPIEDAD RURAL

Teléfano de cantacta:

Recibic:

NOMARE FIRMA

c.C. No. CEIULAR 


\section{Anexo F: Carteleras del cronograma de visitas en la Alcaldía de Ramiriquí, oficina USTA y escuela Pabellón}

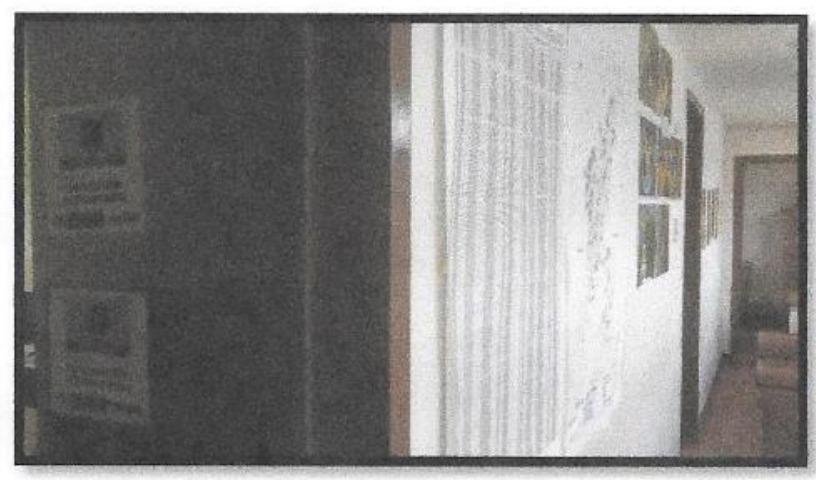

Cronograma de Visitas en Oficina USTA
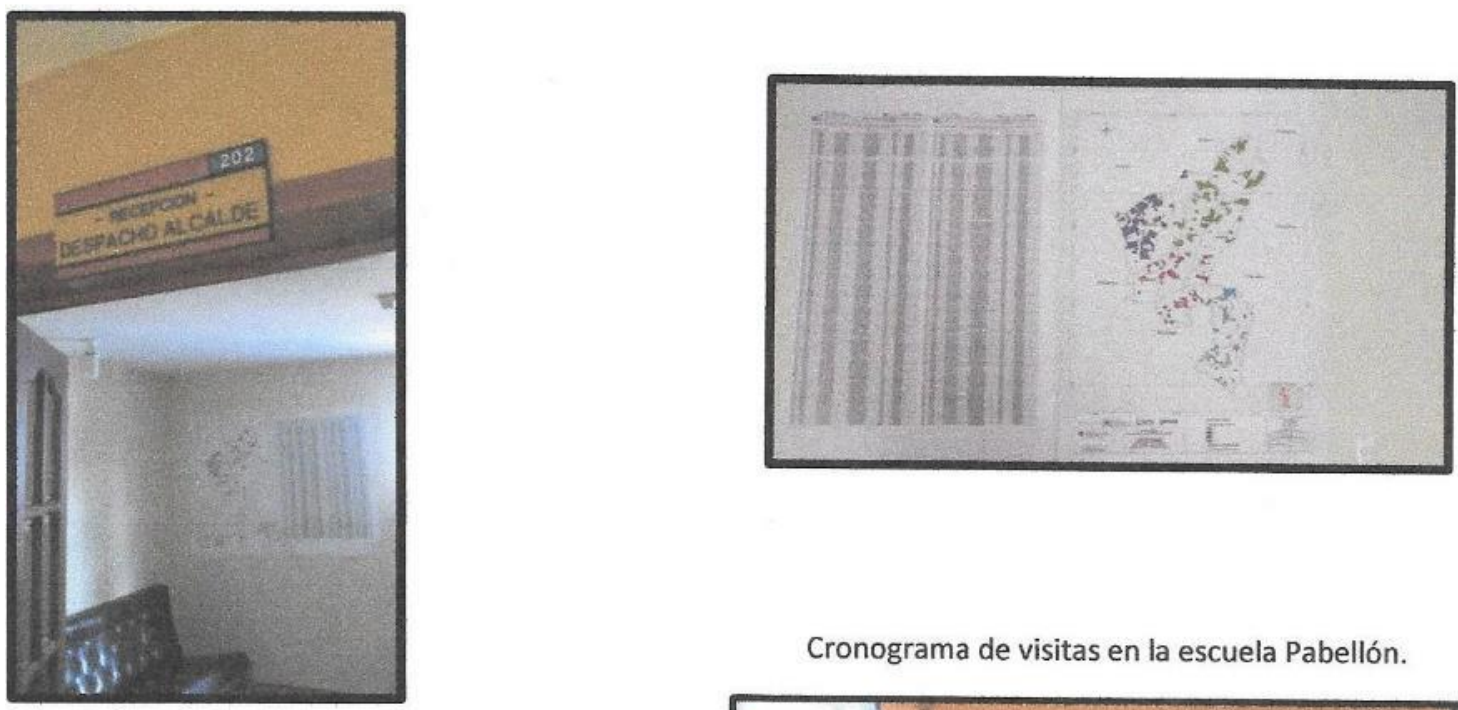

Cronograma de visitas en la escuela Pabellón.

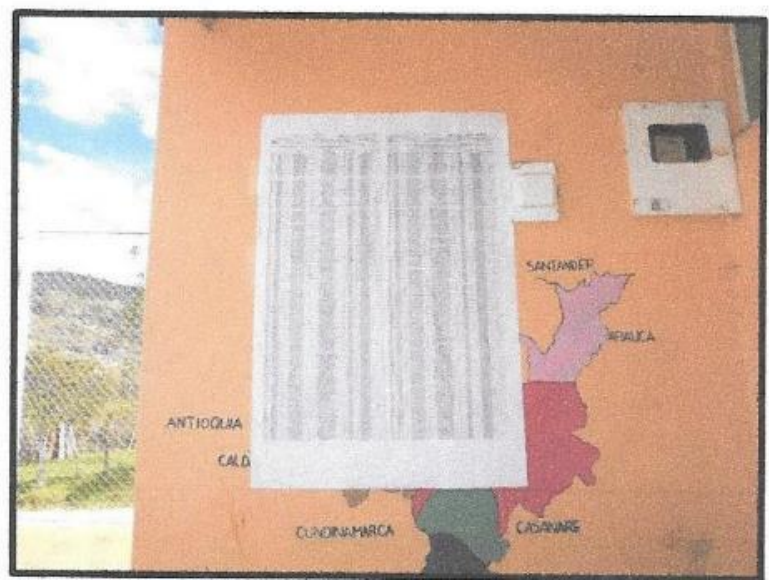




\section{Anexo G: Alcance de las jornadas de socialización}

\begin{tabular}{|c|c|c|}
\hline \multicolumn{3}{|c|}{ ALCANCE DE LAS JORNADAS DE SOCIALIZACIÓN } \\
\hline Orden temático & Objetivo & $\begin{array}{l}\text { ítems a considerar / preguntas a } \\
\text { resolver dentro de la socialización. }\end{array}$ \\
\hline $\begin{array}{l}\text { 1. Conceptos } \\
\text { básicos }\end{array}$ & $\begin{array}{l}\text { Que el usuario se identifique } \\
\text { como informalidad y pueda } \\
\text { comprender la importancia de } \\
\text { iniciar un proceso de } \\
\text { regularización de la propiedad. }\end{array}$ & $\begin{array}{ll}\checkmark & \text { Qué es la informalidad? } \\
\checkmark & \text { Quiénes son informales? } \\
\checkmark & \text { Qué es ser propietario? } \\
\checkmark & \text { Clases de informalidad? } \\
\checkmark & \text { Desventajas de la informalidad? } \\
\checkmark & \text { Ventajas de ser propietario? } \\
\checkmark & \text { Efectos de Sociedades Conyugales y } \\
& \text { Patrimoniales. } \\
\checkmark & \text { Efectos de áreas y linderos. } \\
\checkmark & \text { Efectos de estar inscrito en el } \\
& \text { catastro. } \\
\checkmark & \text { Forma de propiedad en comunidad. }\end{array}$ \\
\hline $\begin{array}{l}\text { 2. Presentación } \\
\text { del Programa: }\end{array}$ & $\begin{array}{l}\text { Presentar a la comunidad los } \\
\text { programas de la ANT }\end{array}$ & 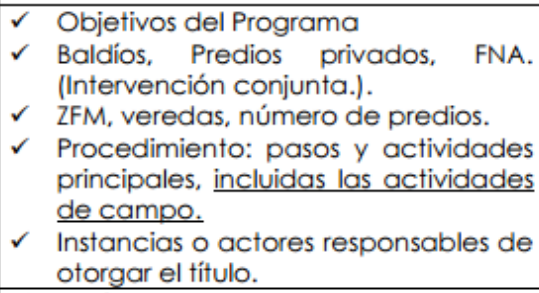 \\
\hline $\begin{array}{l}\text { 3. Alcance del } \\
\text { Programa }\end{array}$ & $\begin{array}{l}\text { Entregar información clara a la } \\
\text { comunidad acerca del criterio } \\
\text { de gratuidad y subsidiariedad } \\
\text { del Programa. }\end{array}$ & $\begin{array}{l}\checkmark \text { Qué aporta el programa? (Costos del } \\
\text { proceso y gastos procesales). } \\
\checkmark \quad \text { Qué aporta el usuario? } \\
\text { (Documentos, tiempo, información } \\
\text { veraz, gastos procesales, umbral del } \\
\text { SISBEN). } \\
\checkmark \quad \text { Requisitos de adjudicabilidad. } \\
\checkmark \text { Tiempos del proceso. }\end{array}$ \\
\hline $\begin{array}{l}\text { 4. Información } \\
\text { referente al } \\
\text { próximo } \\
\text { encuentro }\end{array}$ & $\begin{array}{l}\text { Indicar al posible beneficiario } \\
\text { del Programa los detalles de la } \\
\text { jornada de recepción de } \\
\text { solicitudes. }\end{array}$ & $\begin{array}{l}\text { Explicar la operación de la jornada } \\
\text { de recepción de solicitudes. } \\
\checkmark \text { Documentos que tienen que aportar } \\
\text { en la jornada de recepción. } \\
\checkmark \quad \text { Fechas, horas y lugar de la jornada } \\
\text { de recepción. }\end{array}$ \\
\hline 5. Varios & $\begin{array}{l}\text { Atender otros temas que el líder } \\
\text { del proceso considere } \\
\text { pertinente, siempre y cuando } \\
\text { esté relacionado con el } \\
\text { proceso. } \\
\end{array}$ & $\begin{array}{l}\checkmark \text { Respuesta de dudas e inquietudes } \\
\text { por parte de la comunidad. } \\
\checkmark \text { Datos de contacto, oficina, horarios } \\
\text { de atención. }\end{array}$ \\
\hline
\end{tabular}

